\title{
ELEVATION OF SURFICIAL SEDIMENT/BASALT CONTACT \\ IN THE SUBSURFACE DISPOSAL AREA, \\ IDAHO NATIONAL ENGINEERING LABORATỌY
}

\author{
J. M. Hubbel1 \\ Applied Geosciences Unit \\ Earth, Environmental and Life Sciences Group
}

May 1993
Idaho National Engineering Laboratory EG\&G Idaho, Inc.
Idaho Falls, Idaho 83415

Prepared for the

U.S. Department of Energy

Office of Environmental Restoration and Waste Management

Under DOE Field Office, Idaho

Contract AC07-76ID01570 


\section{ELEVATION OF SURFICIAL SEDIMENT/BASALT CONTACT \\ IN THE SUBSURFACE DISPOSAL AREA, IDAHO NATIONAL ENGINEERING LABORATORY}

Reviewed by:

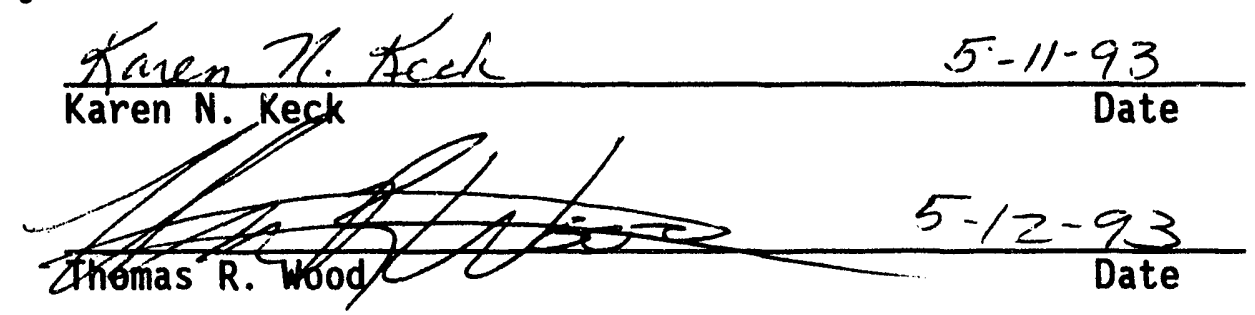




\section{ABSTRACT}

The elevation of the surficial sediment/basalt contact at the Subsurface Disposal Area (SDA), within the Radioactive Waste Management Complex (RWMC) is presented to provide a data base for future remedial actions at this site. About 1300 elevation data from published and unpublished reports, maps, and surveyors notes were compiled to generate maps and cross-sections of the surficial sediment/basalt contact. In general, an east to west trending depression exists in the south central portion of the SDA with basalt closer to 1 and surface on the northern and southern boundaries of the SDA. The lowest elevation of the surficial sediment/basalt contact is $4979 \mathrm{ft}$ and the greatest is land surface at $5012 \mathrm{ft}$. The median elevation of the sediment/basalt interface is $4994 \mathrm{ft}$. The median depth to basalt in the SDA is $16 \mathrm{ft}$ if land surface elevation is assumed to be $5010 \mathrm{ft}$. The depth from 1 and surface to the sediment/basalt interface ranges from $24 \mathrm{ft}$ in the southeast corner of the SDA to less than $3 \mathrm{ft}$ at the north-central boundary of the SDA. 


\section{CONTENTS}

ABSTRACT. .................................

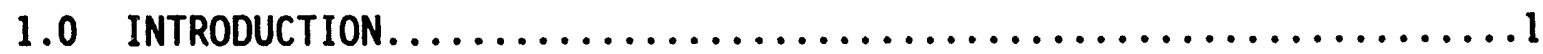

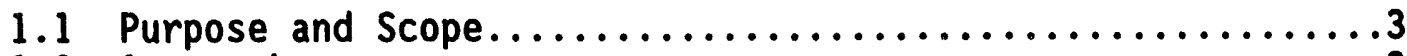

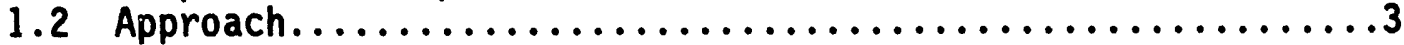

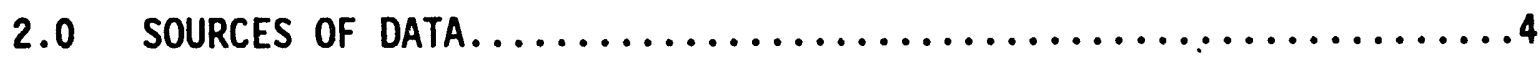

2.1 Published Sources of Data.......................

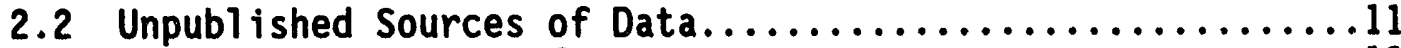

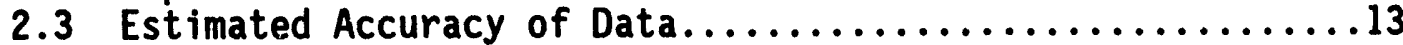

2.4 Data Validation (Verification of Data) ................

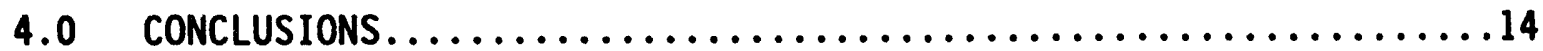

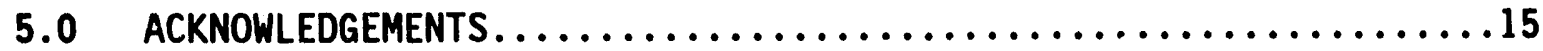

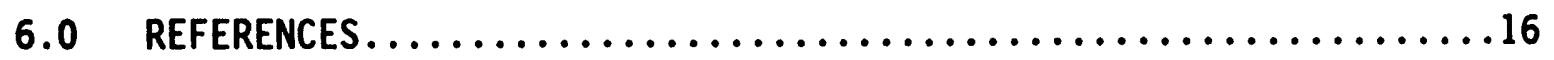

APPENDIX A--COORDINATES AND ELEVATIONS OF THE SURFICIAL

SEDIMENT/BASALT CONTACT IN THE SDA...............

\section{FIGURES}

1. Location of Subsurface Disposal Area, Radioactive Waste

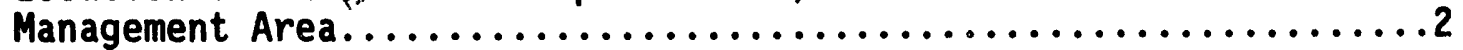

2. Elevation of Surficial Sediment/Basalt Contact.............. Folder

3. Elevation of Surfical Sediment/Basalt Contact

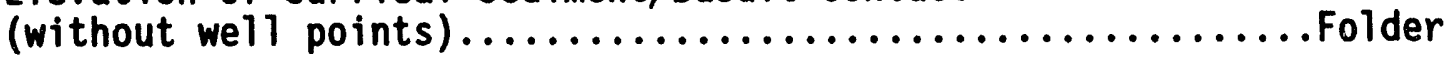

4. Elevation of Surficial Sediment/Basalt Contact Contour.........5

5. Elevation of Surficial Sediment/Basalt Contact With

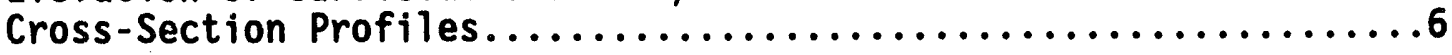

6. SDA Cross Section: Profile $A-A^{\prime} \ldots \ldots \ldots \ldots \ldots \ldots \ldots \ldots \ldots$

7. SDA Cross Section: Profile B-B' $\ldots \ldots \ldots \ldots \ldots \ldots \ldots \ldots \ldots \ldots$

8. SDA Cross Section: Profile $C-C^{\prime} \ldots \ldots \ldots \ldots \ldots \ldots \ldots \ldots \ldots \ldots$

9. SDA Cross Section: Profile D-D' $\ldots \ldots \ldots \ldots \ldots \ldots \ldots \ldots \ldots \ldots$

10. SDA Cross Section: Profile E-E' $\ldots \ldots \ldots \ldots \ldots \ldots \ldots \ldots \ldots$ 
11. SDA Cross Section: Profile F-F' $F^{\prime} \ldots \ldots \ldots \ldots \ldots \ldots \ldots \ldots \ldots$

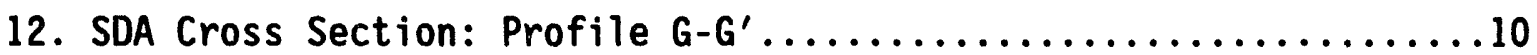

13. SDA West/East Cross Section: Profile H-H.................Folder 


\section{ELEVATION OF THE SURFICIAL SEDIMENT/BASALT CONTACT \\ IN THE SUBSURFACE DISPOSAL AREA, IDAHO NATIONAL ENGINEERING LABORATORY}

\subsection{INTRODUCTION}

The Radioactive Waste Management Complex (RWMC) is located in the southeastern portion of the Idaho National Engineering Laboratory (INEL) in Southeastern Idaho (Figure 1). The INEL covers about $894 \mathrm{mi}^{2}$ of the Eastern Snake River Plain. The Eastern Snake River Plain is an arcuate depression that ranges from 30- to $70-\mathrm{mi}$ wide and is approximately $200-\mathrm{mi}$ long. The plain has an average elevation of $4900 \mathrm{ft}$ and is bounded by mountains and high plateaus.

The RWMC was established in 1952 and has served as a storage and disposal site for low-level and transuranic radioactive waste. Hazardous waste, primarily organic solvents, were disposed with the radioactive waste in the 1960's and 1970's. The RWMC is made up of two areas: the Subsurface Disposal Area (SDA) and the Transuranic Storage Area (TSA). This report will focus on the elevation of the surficial sediment/basalt contact within the SDA. The SDA contains waste materials disposed of below land surface within the surficial sediments in shallow pits, trenches, and soil vaults. The depth to basalt in the SDA has determined how and where wastes were buried at the SDA (Schmalz, 1972). From 1952 to 1970 wastes were often disposed directly on top of the basalt without a sediment layer underlying the waste. A two foot layer of sediment has been placed beneath waste buried after 1970 (Anonymous, 1985) since fine grained sediments attenuate the migration of waste materials.

Data presented in this report may be used to predict areas within the SDA which are more or less likely to allow migration of waste products into the underlying basalt. The depth to the surficial sediment/basalt contact or thickness of the surficial sediment can be used to calculate the total volume of sediment present at a given location. 


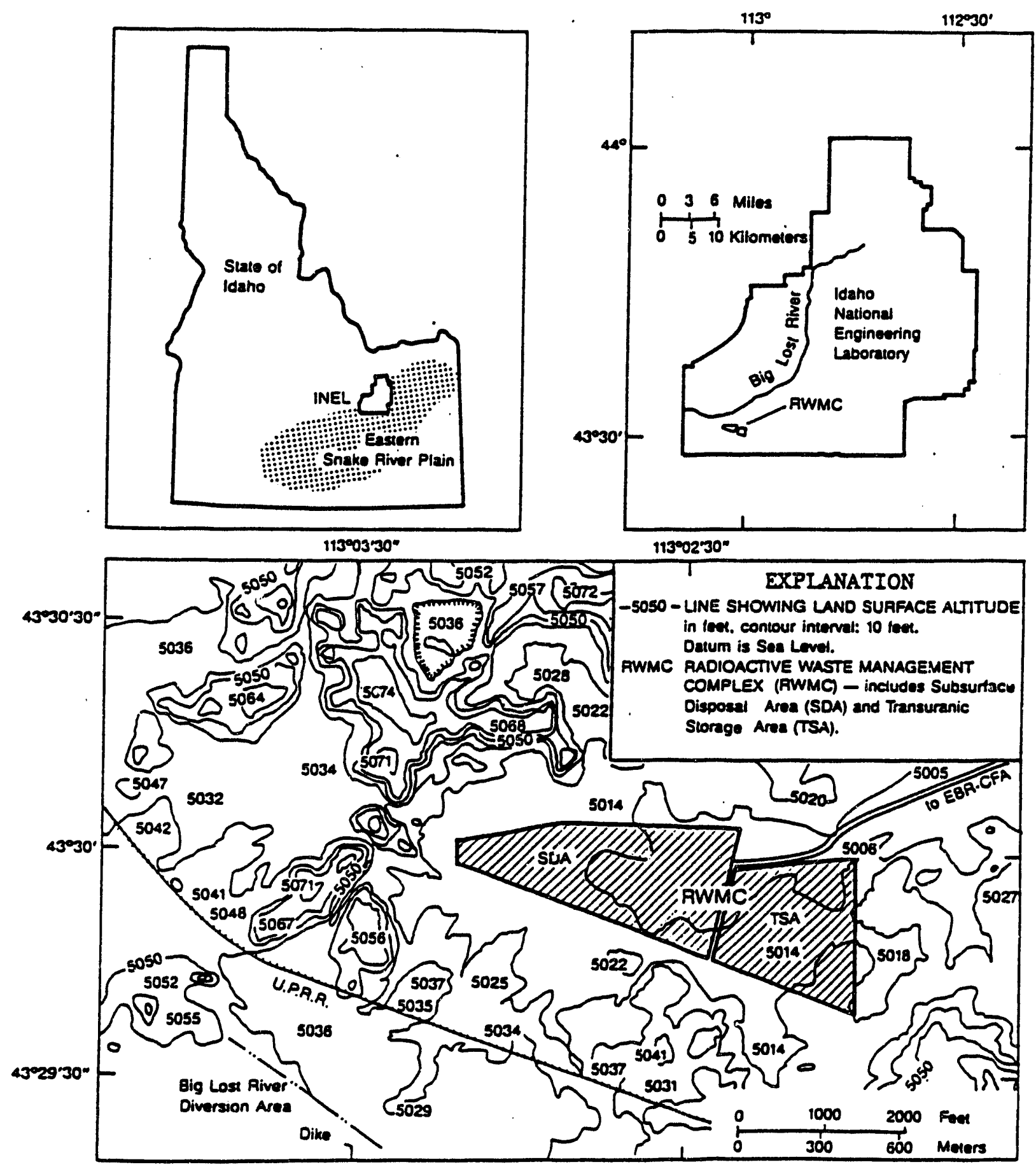

Figure 1. Location of the Subsurface Disposal Area, Radioactive Waste Management Complex, INEL. 


\subsection{Purpose and Scope}

The purpose of this investigation is to define the elevation of the surficial sediment/basalt interface beneath the SDA at the RWMC using all pertinent information. This interface is referred to as the elevation of the basalt, the base of the surficial sediment, or the surficial sediment/basalt interface or contact. Plan-view drawings and cross-sections are used to present this information. This report builds upon work presented by Schmalz (1972), Barraclough (1976), Anonymous (1983), Laney et al. (1988), Rightmire and Lewis (1987), and Anderson and Lewis (1989), all of which generated figures presenting the depth of basalt. Several sources of unpublished data (primarily drawings) have also been used to complete this report.

\subsection{Approach}

Data on depth (elevation) of basalt at the SDA were compiled from 15 sources including published reports and unpublished drawings and documents. The reliability of the data sources were confirmed by cross-checking with other data sources, field checks, and from discussions with site personnel. Recorded coordinates, using the INEL Coordinate system, were input into the data base along with the elevation of the basalt. Appendix A contains a paper copy of the data base used to generate the drawings of the SDA. It contains over 1300 data points with easting, northing, elevation of basalt, and a reference as to the source of information. Some data sources contained information on land surface elevation and the depth to basalt from a measuring point. Data from drawings of the SDA were digitized to obtain the northing and easting for many sites within the SDA.

Drawings by Aerial Mapping Co. $(1980,1987)$ were used to determine the land surface elevation for the boreholes that were not surveyed. Elevations of the surfical sediment/basalt interface were calculated using depth below land surface along with the land surface elevation from the Aerial Mapping drawings. The drawing with the date closest to the date the borehole was drilled was used for the elevation determination. Soil recontouring efforts within the SDA in the 1980's has changed the land surface elevation up to 8 
feet, making surface elevation determination difficult.

Data were input into a LOTUS data base and input into the SURFER (Golden Software Inc., 1989) plotting/contouring computer program for generating Figures 2 through 4 . The contour maps were generated using the minimum curverature option and a smoothing function. Boundary points were placed outside the border of the SDA on approximate $500 \mathrm{ft}$ intervals with known basalt elevations to provide reasonable contours near the borders of the SDA (Figure 5). The elevations for these points were estimated based on drilling data from wells outside the SDA. Figure 5 presents the locations of crosssections $A-A^{\prime}$ to $H-H^{\prime}$ presented in Figures 6 through 12. All the north-south cross sections have the same scale and have the same end points as shown in Figure 5. The cross sections were digitized from the contour map presented in Figure 2. Land surface was approximated for these figures with a horizontal line at $5010 \mathrm{ft}$ which is the average surface elevation in the SDA. It should be noted that the figures are presented with the contact of the surficial sediment/basalt interface intact within pits 17 through 20 . Sediment and basalt was removed to an elevation of $4980 \mathrm{ft}$ while excavating materials to construct these pits.

\subsection{SOURCES OF DATA}

Data on the elevation of the surficial sediment/basalt interface were obtained from 5 published reports and 10 unpublished sources. These data are compiled in Appendix $A$ and a description of the sources of data are presented in subsequent sections.

\subsection{Published Sources of Data}

Data on the elevation of basalt within the SDA were obtained from 5 reports. Anderson and Lewis, 1989, compiled elevation data for the base of the surficial sediments from wells drilled into basalt at the RWMC from 1972 to 1989 . These data were input directly into the data base and combined with the surveyed coordinates from wells presented in a drawing by Scott, 1988. Data from Hubbell et al., $(1986,1987)$ and Laney (1987) provide information on depths to basalt from shallow and deep wells drilled within the SDA. The 


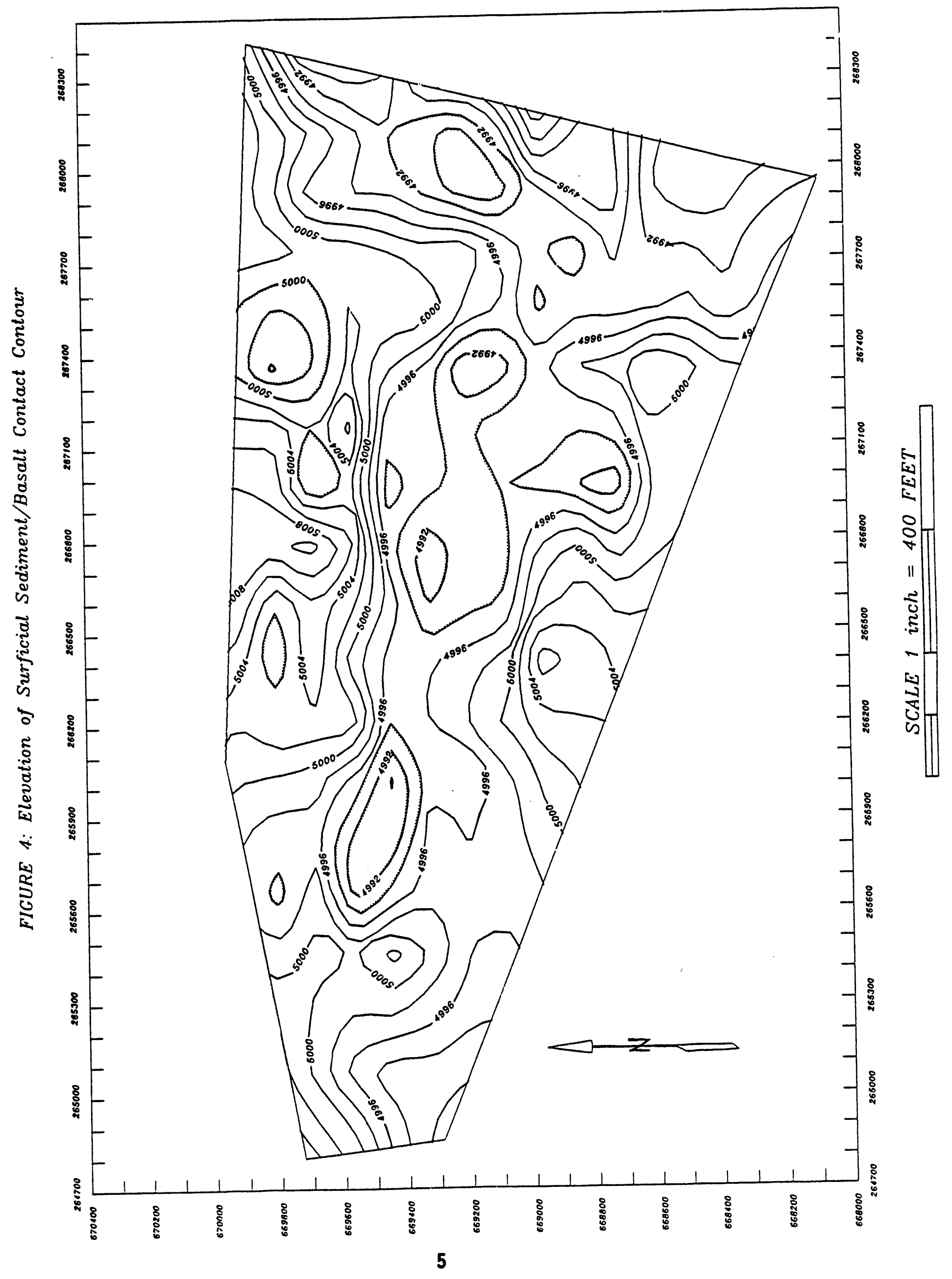




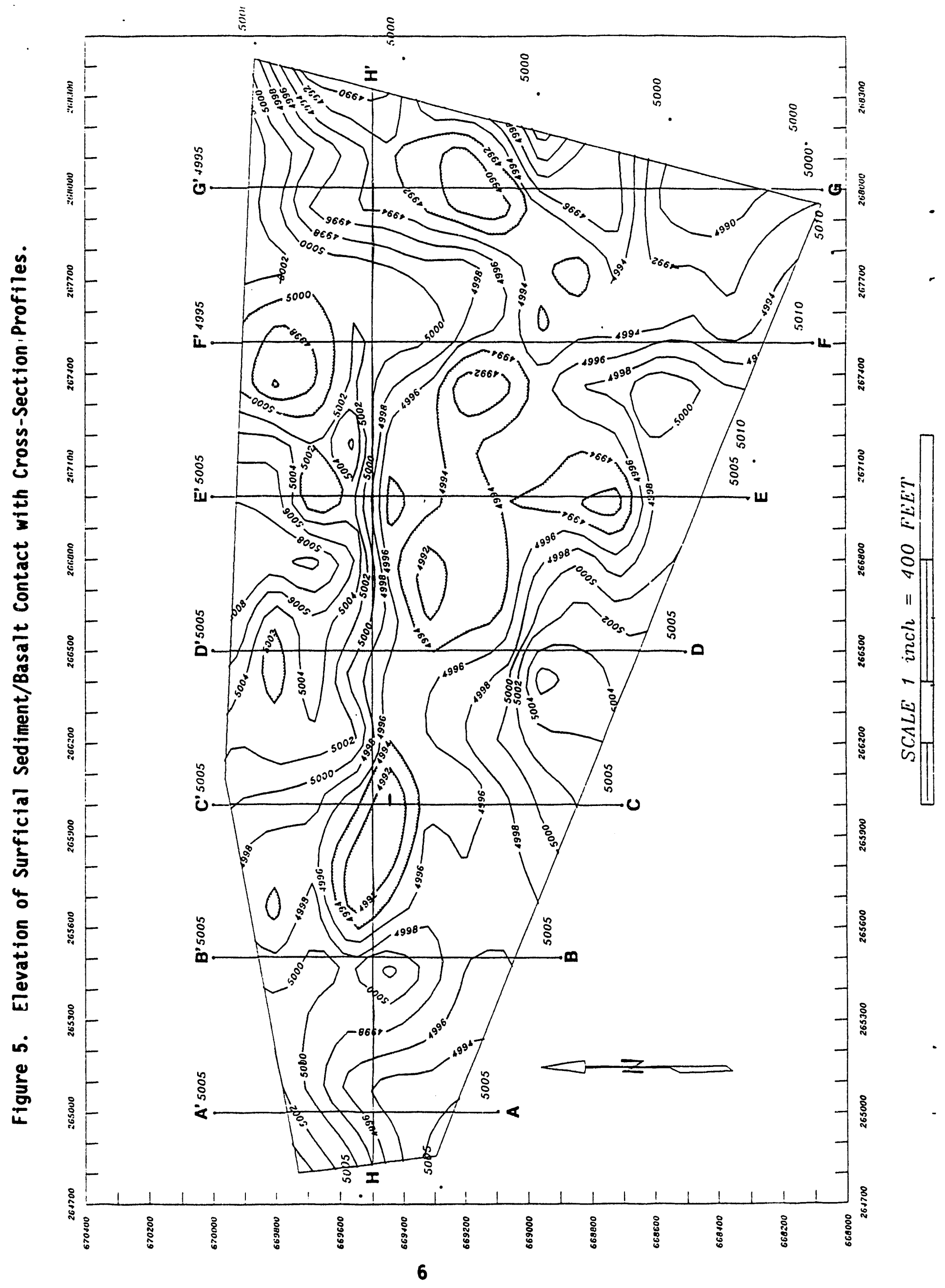




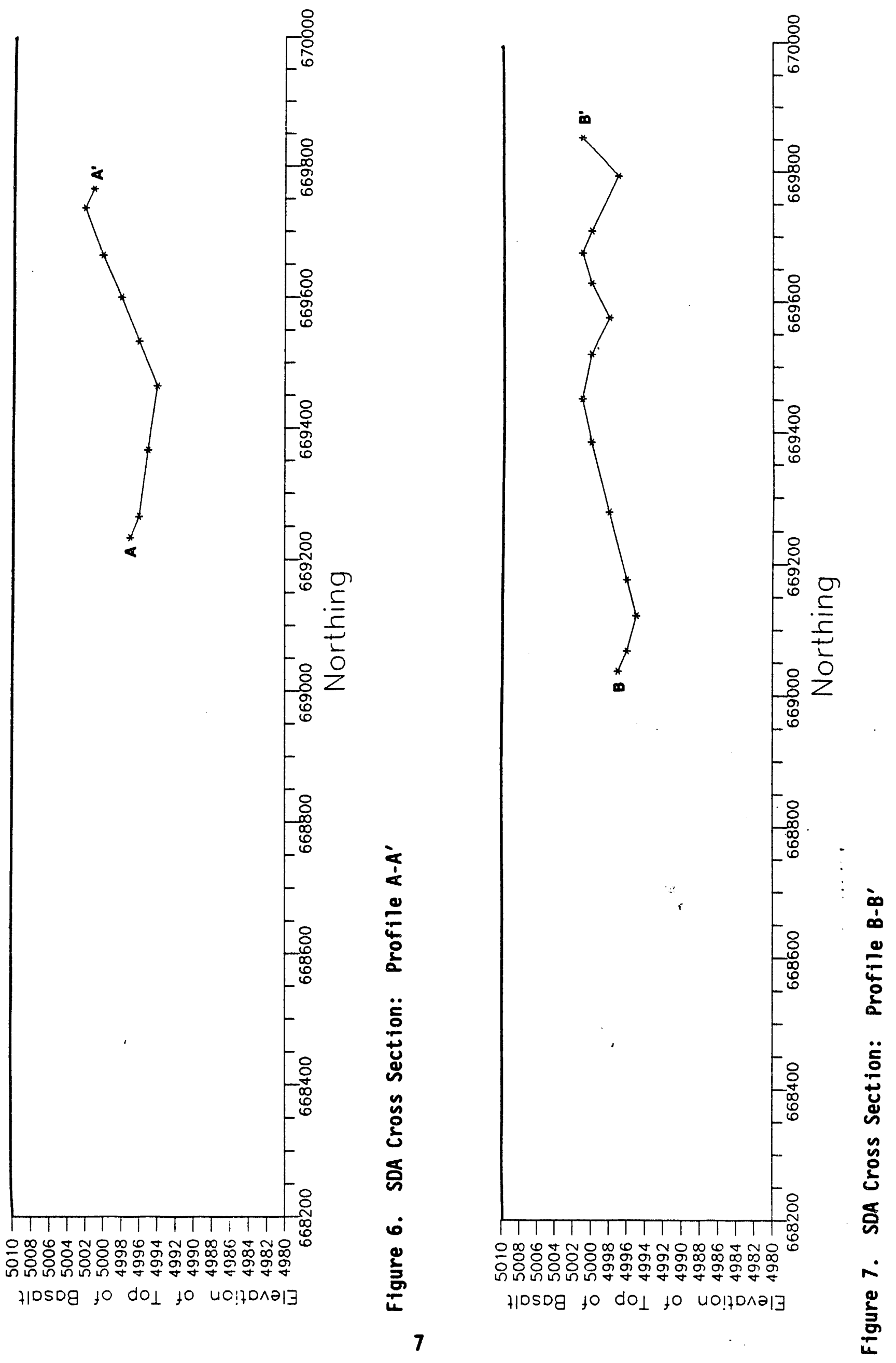



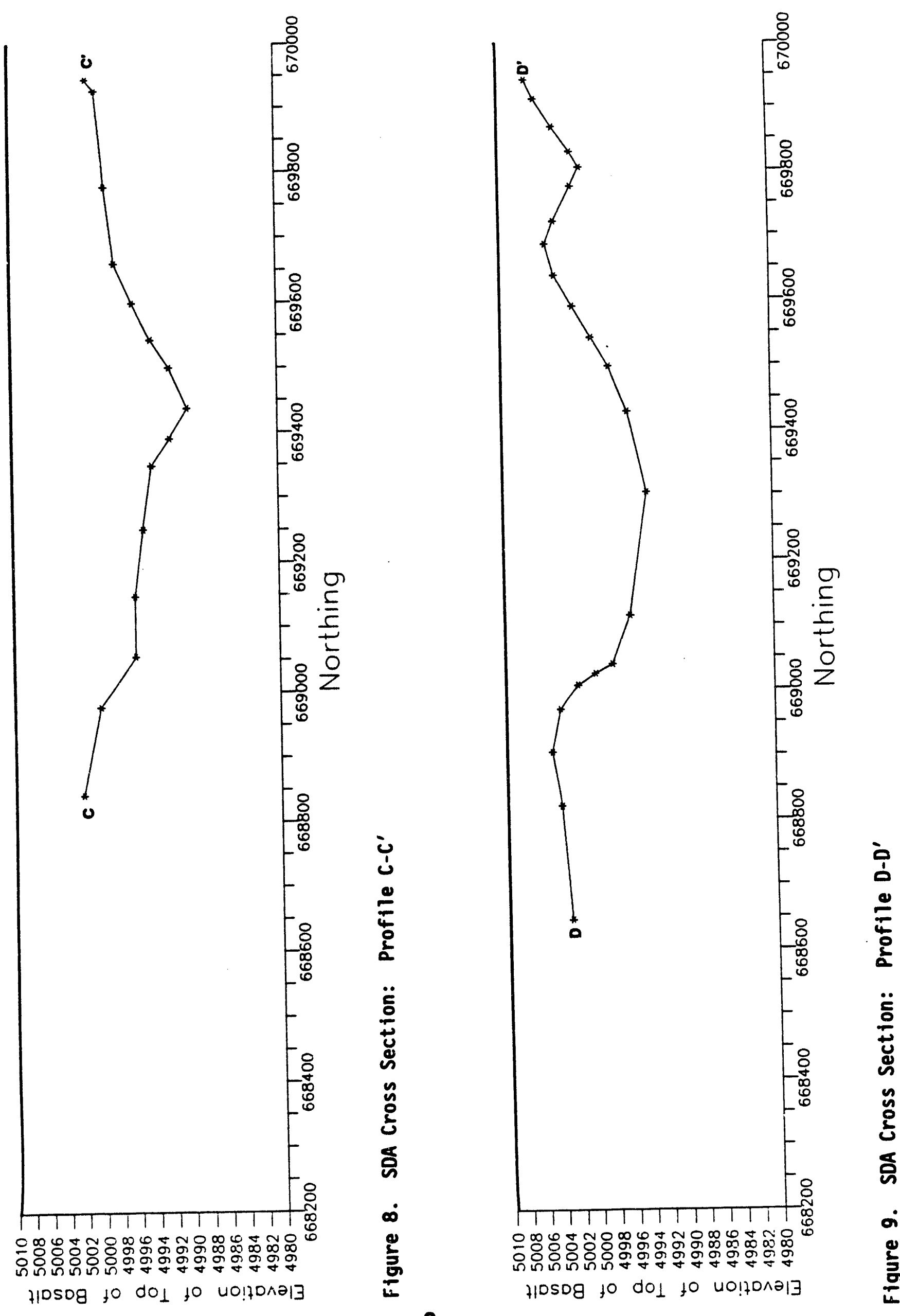

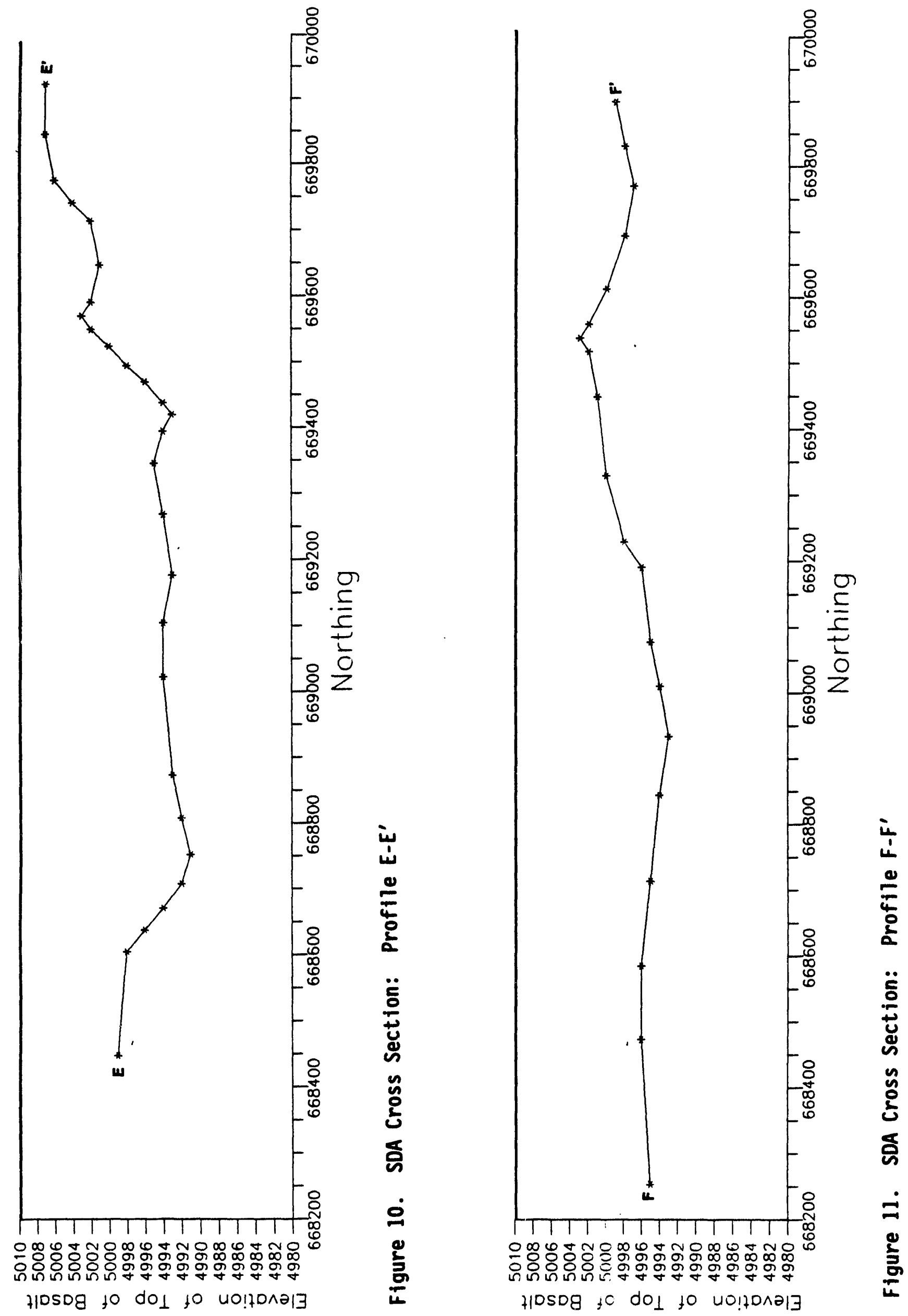


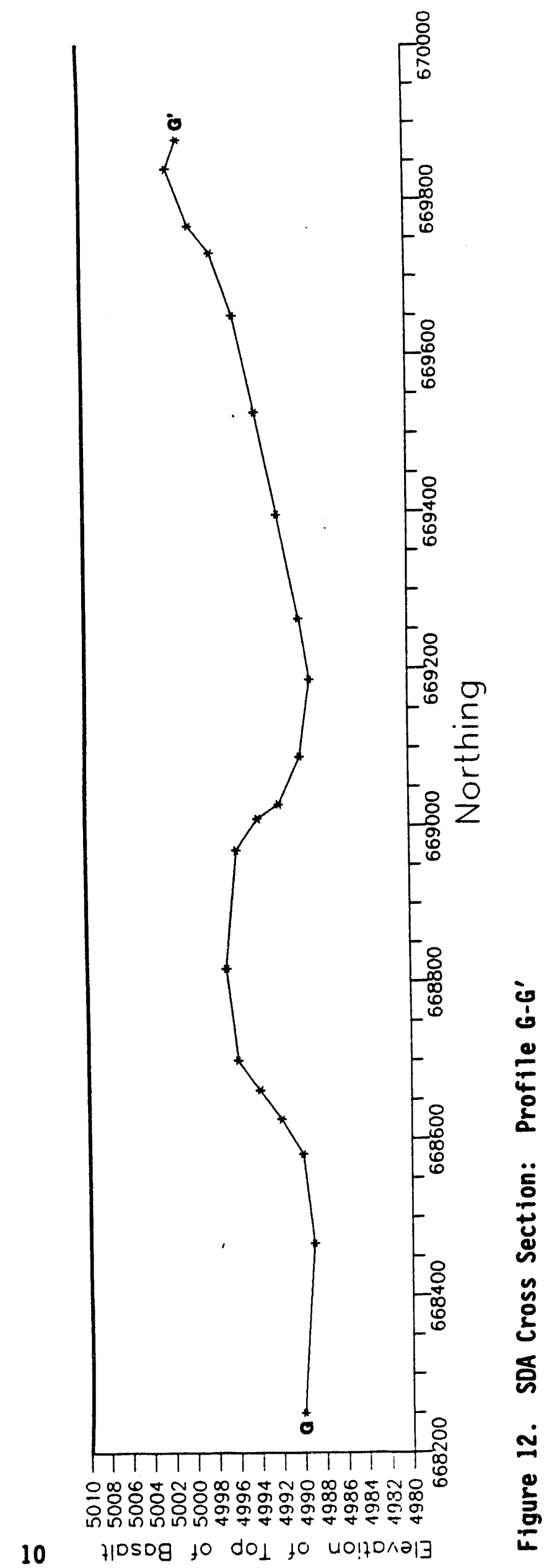


coordinate and elevation data is compiled in a report by Paarmann, 1991. Coordinate and elevation data from all the published sources were taken from actual survey notes.

\subsection{Unpublished Sources of Data}

Ten sources of unpublished data were compiled to delineate the depth (elevation) of basalt. The unpublished sources are from maps and drawings of drill holes and exposures of the surficial sediment/basalt contact in the SDA.

Seven hundred and seventy one holes were augured in the eastern portion of the SDA in the late 1960's or 1970. The location and elevation of basalt was recorded in a series of 11 drawings (Idaho Nuclear Corporation, 1970 Drawings 1230-BFG-003-1 through 11). Data from the Idaho Nuclear Corporation drawings were digitized using AutoCAD to obtain the coordinates and the data were combined with the elevation printed on the drawings. The Idaho Nuclear Corporation drawings were plotted at a scale of 1 inch equals $20 \mathrm{ft}$.

Johnson (1960) provides a drawing for the SDA showing depth of surficial sediments from auger holes drilled prior to 1960 . Original surveyor notes are not available for this data. The locations of these auger holes were digitized off the original map to determine the northing and easting coordinates. The scale of the drawing is 1 inch equals $200 \mathrm{ft}$. Depths to basalt recorded as greater than 12.5 feet (marked as $12.5+$ ) are included in the LOTUS data base but the elevations were not used in generation of Figures 2 through 13. Depths of basalt were input to the data base and the depth subtracted from the elevation at these sites from the drawing by Aerial Mapping Co., 1980. The Aerial Mapping Co. drawing provides the best estimate of the elevation at the time of placement of the borings. A map generated from these data was presented by Schmalz (1972).

Locations of "monitoring stations" were digitized from a drawing by Scott, 1991. The scale of the drawing is 1 inch equals approximately $143 \mathrm{ft}$. The drawing by Scott (1991) includes the location and depths to basalt in these holes. A report by Barraclough (1976) provided additional locations for 
the access tubes labeled as "removed". Depth was subtracted from land surface elevation from the drawing by Aerial Mapping Co., 1980. Several monitoring stations still exist and the surveyed coordinates included in the data base.

Elevation of the surficial sediment/basalt interface was surveyed in the wall of open pits 17 through 20 in 1989. The data was input directly into the data base from survey notes by Sutherlin and King, 1989.

Soil vaults have been placed in the SDA at approximately 600 locations. Soil vaults are 1.5 to $5 \mathrm{ft}$ diameter cylinders which are buried in the surficial sediments. Auger holes are drilled to the bottom of the surficial sediments, the depth recorded, at least two feet of sediment backfilled in the hole and then the vault placed in the hole. Soil vaults are installed in long rows at 4 to $20 \mathrm{ft}$ intervals. Location of the soil vaults are measured in the field from the surveyed end markers. Data were obtained from numerous record books at the RWMC which contain the distance from a surveyed end marker and the depth of basalt. Surveyed end markers and distances were plotted and the information digitized to calculate the coordinates. Land surface elevation was taken from drawings produced by Aerial Mapping Co. $(1980,1987)$. Only a limited number of the soil vault row data points were obtained for soil vaults prior to 1982, since these records have been sent to records storage. Twenty soil vault rows have been placed in the SDA; however, data was only available for 360 points in Soil Vault Rows 9 through 20.

Twenty two auger holes were drilled through and around the asphalt pad of Pad A. Data were obtained from an original drawing by Bob Brown, recorded in 1986. Data were digitized from a photocopy of his drawing. This drawing has a scale of 1 inch equals $50 \mathrm{ft}$. The points were measured with a tape and the data referenced to land surface elevation (Aerial Mapping Co., 1987). The auger holes running down the center of $P$ ad $A$ use the land surface elevations from the asphalt pad and not sediment overlaying the pad, which is consistent with the field measurements.

Data were obtained from sonic drilled holes around the Acid Pit and Pit 9. All sonic drilled holes were surveyed with north-east coordinates and 
elevation accurate to at least $0.1 \mathrm{ft}$. The depth to basalt was obtained from Kuhns (1992, personal communication).

\subsection{Estimated Accuracy of Data}

The relative accuracy of the various data sets have been estimated for the northing and easting coordinates and elevation. It is difficult to assign an absolute accuracy to any of the data except those points that were surveyed. Data from Anderson and Lewis (1989), Hubbell, et a1. (1986, 1987), Paarmann et al. (1991), Sutherlin and King (1989) and Kuhns (1992), was obtained from actual surveyed sites which have the best accuracy of $0.1 \mathrm{ft}$ or better. Data presented in Appendix A contains a column labeled "Reference Number" that corresponds to these references (refer to page A-2 for cross reference).

Northing and easting coordinates for data from Idaho Nuclear Corporation (1970), Johnson (1960), Brown (1986), and Scott (1991) were obtained from digitizing points from maps. The elevations were obtained by subtracting field measurements of depth to basalt from the elevation on drawings by Aerial Mapping Co. $(1980,1987)$. The elevations from the Aerial Mapping Co. contour maps are assumed to be plus or minus the contour interval $(0.5 \mathrm{ft})$ or $1 \mathrm{ft}$. For points obtained from digitizing the northing and easting coordinates it is assumed that the maps are correct and the digitizing accuracy is within 1/10 (0.1) of an inch, using the scale of the map. The "relative accuracy" is then calculated by multiplying the scale in feet times 0.1 . The drawing by Idaho Nuclear Corporation (1970) is at a scale of 1 inch equals $30 \mathrm{ft}$ so the relative accuracy is within $3 \mathrm{ft}$. The drawing by Johnson (1960) has a scale of 1 inch equals $200 \mathrm{ft}$, so the relative accuracy is within $20 \mathrm{ft}$. Data from Brown (1986) is at a scale of 1 inch equals $50 \mathrm{ft}$, so the relative accuracy is within $5 \mathrm{ft}$. The monitoring stations presented in Scott (1991) are plotted at a scale of approximately 1 inch equals 143 feet, so the relative accuracy is $14 \mathrm{fi}$.

Yokuda (1991) estimated the accuracy of the surveyed markers for the soil vault rows. Rows 17 through 20 were surveyed in 1991 and are probably 
accurate to within $0.1 \mathrm{ft}$, rows $9,10,11,14$ and 16 are probably accurate within plus or minus $4 \mathrm{ft}$, rows 12 and 13 are plus or minus $5 \mathrm{ft}$, and row 13 is plus or minus $5 \mathrm{ft}$ in the north-south direction and plus or minus 30 feet in the east-west direction. Locations of the soil vaults were measured relative to these markers and were probably measured within a foot of the location.

\subsection{Data Validation (Verification of Data)}

Data used in this report were transcribed from various sources and placed in an ASCE file. All data in the ASCE file were checked against the original file or the original data. Data were plotted and checked for accurate locations and elevations.

\subsection{CONCLUSIONS}

The surface of the surficial sediment/basalt contact within the SDA ranges from an elevation of 4979 to $5012 \mathrm{ft}$. The mean elevation of the interface is $4994 \mathrm{ft}$. The depth to basalt from land surface varies from 0 to over 25 feet with a mean depth of 16 feet. The elevation of the basalt reflects the depositional pattern of the basalt flows, with sediment deposited on top of the basalt. The elevation of the surficial sediment/basalt interface is lowest in the central portion of the SDA near the eastern boundary and highest on the northern and southern borders of the SDA. Data from this report were input into the ERIS data base system. 


\subsection{ACKNOWLEDGEMENTS}

I wish to acknowledge Mike Carpenter for digitizing data, inputting data into the database, and producing cross sections and plan view drawings for this report. I also want to thank Lee Frieburger, Mike Towler, Mary Walker, and Kent Sorenson for inputting data into the data base. I appreciate Kirk Dooley for supporting this project to get these data into a useable database. Mention of specific products and/or manufacturers in this document implies neither endorsement of preference nor disapproval by the U.S. Government, any of its agencies, or EG\&G Idaho Inc. of the use of a specific product for any purpose. 


\subsection{REFERENCES}

Aerial Mapping Co. 1980, Idaho National Engineering Laboratory, Radioactive Waste Management Complex, Land Surface Contour Map of the Subsurface Disposal Area, Scale 1 inch equals $100 \mathrm{ft}$, contour interval 0.5 ft, April 8, 1980, Boise ID.

nerial Mapping Co., 1987, SDA-Contour Map, INEL (RWMC) SDA, Scale 1 inch equals $100 \mathrm{ft}$, Contour interval $0.5 \mathrm{ft}$, Index Number 0980000 - 601356697 , December 4, 1987, Boise ID.

Anderson, S. R. and B. D. Lewis, 1989, Stratigraphy of the Unsaturated Zone at the Radioactive Waste Management Complex, Idaho National Engineering Laboratory, U. S. Geological Survey, Water Resources Investigations Report 89-4065, DOE/ID-22080.

Anonymous, 1983, A Plan for Studies of Subsurface Radionuclide Migration at the Radioactive Waste Management Complex of the Idaho National Engineering Laboratory, Vol. 1 and 2, November, DOE/ID-i0116

Anonymous, 1985, A History of the Radioactive Waste Management Complex at the Idaho National Engineering Laboratory, Internal Technical Report, WM-F1-81-003, Rev. 3, July.

Barraclough, J. T., J.B. Robertson, and V.J. Jazner, 1976, Hydrology of the Solid Waste Burial Ground, As Related to the Potential Migration of Radionuclides, Idaho National Engineering Laboratory, IDO-22056, August.

Brown, B., 1986, Unpublished drawing of auger borings around Pad A.

Golden Software, Inc., 1989, SURFERe, Reference Manual, Version 4.01, Golden Software, Inc., Golden, Colorado.

Hubbe11. J. M., L. C. Hu11, T. G. Humphrey, B. F. Russe11, J. R. Pittman, and P. R. Fischer, 1987, Annual Progress Report: FY-86, Subsurface Investigations Program at the Radioactive Waste Management Complex of the Idaho National Engineering Laboratory, DOE-ID 10153, Jan.

Hubbe11, J. M., L. C. Hul1, T. G. Humphrey, B. F. Russe11, J. R. Pittman, and R. M. Cannon, 1986, Annual Progress Report: FY-85, Subsurface Investigations Program at the Radioactive Waste Management Complex of the Idaho National Engineering Laboratory, DOE-ID 10136, Dec.

Idaho Nuclear Corporation, 1970, Drawings entitled "Burial Ground Probe Hole Logs and Burial Elevations", Drawings Generated by Idaho Nuclear Corporation, DWG. NOS. 1230-BGF-003-1 to 1230-BEG-003-11, 11 figures.

Johnson, B. M., 1960, Map of the SDA entitled "National Reactor Testing Station Plan of BURIAL GROUND AREA Showing SOIL PROFILE SURVEY", DWG No. BGF-001-IDO-2, sheet 1 of 1 . 
Kuhns, D. L., 1992, Personal communication on depth to basalt in sonic drilled wells at the acid pit and Pit 9.

Laney, P. T., S. C. Minkin, R. G. Baca, D. L. McElroy, J. M. Hubbel1, L. C. Hul1, B. F. Russe11, and G. J. Stormberg, 1988, Annual Progress Report: FY-1987, Subsurface Investigations Program at the Radioactive Waste Management Complex of the Idaho National Engineering Laboratory, DOE-ID 10183, Apri1.

Paarmann, M. L., K. L. Ruebelmann and P. B. Swain, 1991, Radioac'́cive Waste Management Complex Investigations Report, EGG-WM-9707, December, Chapter 3.

Rightmire, C. T. and B. D. Lewis, 1987, Hydrogeology and Geochemistry of the Unsaturated Zone, Radioactive Waste Management Complex, Idaho National Engineering Laboratory, Idaho, U. S. Geological Survey, Water-Resources Investigations Report 87-4198, November, DOE/ID-22073.

Schma1z, B. L., 1972, Radionuclide Distribution in Soil Mantle of the Lithosphere as a Consequence of Waste Disposal at the National Reactor Testing Station, ID0-10049, October.

Scott, B. L. 1988, Drawing of RWMC entitled " RWMC BOREHOLE LOCATION", drawing number 426699, August.

Scott, B. L., 1991, Drawing of RWMC entitled "RADIOACTIVE WASTE MANAGEMENT COMPLEX DIAGRAM", drawing Number 416511, drawn 3-9-82.

Sutherlin and King, 1989, Surveying notes for job: SDA Monument Locations, $8 / 14 / 89$ to $9 / 27 / 89$, MK-Ferguson of Idaho Company

Yokuda, E., 1991, Locations of Pits, Trenches, and Soil Vault Rows, Engineering Design File ERP WAG7 05, November. 
COORDINATES AND ELEVATIONS OF THE SURFICIAL SEDIMENT/BASALT CONTACT IN THE SDA 
Data in Appendix A contain information used to calculate the elevation of basalt within the Subsurface Disposal Area, of the Radioactive Waste

Management Complex. The data is referenced to various sources of data. The guide to the references are as follows:

Reference Number

1

2

3

4

5

6

7

8

9

\section{Reference}

Idaho Nuclear Corporation; 1970

Anderson and Lewis, 1989

Hubbell et al., 1986, 1987, Parmann et a1. 1991

Sutherl in and King, 1989

Johnson, 1960, Aerial Mapping Co., 1980

Brown, 1986, Aerial Mapping Co., 1987

RWMC Notebooks-Soil Vault rows, Aerial Mapping Co., 1980 and 1987

Scott, 1991, Aerial Mapping Co., 1980

Kuhns, 1992 
Number Map Easting Northing Basalt Ref MP Depth Comments or ID Elevation Elev. Below Reference

$\begin{array}{rrrlll}1 & 1 & 266954.7 & 669197.2 & 4979.4 & 1 \\ 2 & 2 & 267768.0 & 668853.0 & 4981.6 & 1 \\ 3 & 3 & 267441.8 & 669063.3 & 4982.6 & 1 \\ 4 & 4 & 267842.4 & 668534.6 & 4982.6 & 1 \\ 5 & 5 & 267387.7 & 669156.8 & 4982.8 & 1 \\ 6 & 6 & 267865.4 & 669103.9 & 4983.2 & 1 \\ 7 & 7 & 267373.2 & 669157.3 & 4983.3 & 1 \\ 8 & 8 & 267774.2 & 668892.7 & 4983.3 & 1 \\ 9 & 9 & 267344.0 & 669174.6 & 4983.4 & 1 \\ 10 & 10 & 267357.7 & 669158.3 & 4984.3 & 1 \\ 11 & 11 & 267576.1 & 668790.2 & 4984.3 & 1 \\ 12 & 12 & 267908.3 & 669071.2 & 4984.5 & 1 \\ 13 & 13 & 267907.8 & 669055.8 & 4984.5 & 1 \\ 14 & 14 & 266939.3 & 669198.1 & 4984.6 & 1 \\ 15 & 15 & 267878.5 & 669072.9 & 4984.6 & 1 \\ 16 & 16 & 267877.8 & 669057.7 & 4984.6 & 1 \\ 17 & 17 & 266825.7 & 669074.8 & 4984.7 & 1 \\ 18 & 18 & 267519.3 & 668853.3 & 4984.7 & 1 \\ 19 & 19 & 266855.7 & 669073.4 & 4984.8 & 1 \\ 20 & 20 & 266869.9 & 669057.8 & 4984.8 & 1 \\ 21 & 21 & 266840.0 & 669059.2 & 4984.8 & 1 \\ 22 & 22 & 267359.0 & 669174.1 & 4984.8 & 1 \\ 23 & 23 & 266841.8 & 669089.3 & 4984.9 & 1 \\ 24 & 24 & 267767.1 & 668959.7 & 4984.9 & 1 \\ 25 & 25 & 267826.0 & 668956.2 & 4984.9 & 1 \\ 26 & 26 & 267938.9 & 669069.4 & 4984.9 & 1 \\ 27 & 27 & 267937.9 & 669053.9 & 4984.9 & 1 \\ 28 & 28 & 267631.7 & 668726.7 & 4985.0 & 1 \\ 29 & 29 & 267924.1 & 669070.0 & 4985.0 & 1 \\ 30 & 30 & 266692.0 & 669098.3 & 4985.1 & 1 \\ 31 & 31 & 266854.3 & 669043.1 & 4985.1 & 1 \\ 32 & 32 & 267958.3 & 669128.4 & 4985.1 & 1 \\ 33 & 33 & 267987.5 & 669126.8 & 4985.1 & 1 \\ 34 & 34 & 268050.7 & 669183.0 & 4985.1 & 1 \\ 35 & 35 & 267883.7 & 668892.6 & 4985.1 & 1 \\ 36 & 36 & 267357.1 & 669144.1 & 4985.2 & 1 \\ 37 & 37 & 267372.1 & 669143.3 & 4985.2 & 1 \\ 38 & 38 & 268017.8 & 669124.7 & 4985.2 & 1 \\ 39 & 39 & 267955.4 & 669098.3 & 4985.2 & 1 \\ 40 & 40 & 268058.3 & 669190.9 & 4985.2 & 1 \\ 41 & 41 & 266827.2 & 669104.8 & 4985.3 & 1 \\ 42 & 42 & 268021.3 & 669184.7 & 4985.3 & 1 \\ 43 & 43 & 267985.4 & 669096.3 & 4985.3 & 1 \\ 44 & 44 & 268069.0 & 669227.1 & 4985.3 & 1 \\ 45 & 45 & 268067.8 & 669218.8 & 4985.3 & 1 \\ 46 & 46 & 266938.5 & 669183.6 & 4985.4 & 1 \\ 47 & 47 & 268015.9 & 669094.6 & 4985.4 & 1 \\ 48 & 48 & 268077.3 & 669247.8 & 4985.4 & 1 \\ 49 & 49 & 268072.3 & 669232.8 & 4985.4 & 1 \\ & & & & & \end{array}$

Idaho Nuclear Corporation, 1970 
Number
ID Easting Northing Basalt Ref $\begin{gathered}\text { MP } \\ \text { Elevation }\end{gathered}$ Elev. $\begin{gathered}\text { Depth } \\ \text { Below } \\ \text { MP }\end{gathered}$

$\begin{array}{llllll}\mathbf{5 0} & 50 & 268034.9 & 669119.0 & 4985.4 & 1 \\ \mathbf{5 1} & \mathbf{5 1} & 268015.9 & 669094.2 & 4985.4 & 1 \\ 52 & 52 & 268020.6 & 669075.9 & 4985.4 & 1 \\ 53 & 53 & 268016.3 & 669061.8 & 4985.4 & 1 \\ \mathbf{5 4} & \mathbf{5 4} & 268010.9 & 669048.2 & 4985.4 & 1 \\ 55 & 55 & 266797.7 & 669106.6 & 4985.5 & 1 \\ 56 & 56 & 267329.1 & 669175.6 & 4985.5 & 1 \\ 57 & 57 & 267386.9 & 669142.2 & 4985.5 & 1 \\ 58 & 58 & 268030.0 & 669104.3 & 4985.5 & 1 \\ 59 & 59 & 268025.6 & 669090.6 & 4985.5 & 1 \\ 60 & 60 & 268091.3 & 669290.6 & 4985.6 & 1 \\ 61 & 61 & 267964.5 & 668905.4 & 4985.6 & 1 \\ 62 & 62 & 267359.7 & 669188.9 & 4985.7 & 1 \\ 63 & 63 & 267961.8 & 669188.4 & 4985.7 & 1 \\ 64 & 64 & 267887.2 & 668952.2 & 4985.7 & 1 \\ 65 & 65 & 267865.7 & 668606.2 & 4985.7 & 1 \\ 66 & 66 & 267470.7 & 669036.1 & 4985.8 & 1 \\ 67 & 67 & 267894.2 & 669071.9 & 4985.8 & 1 \\ 68 & 68 & 267771.9 & 669049.3 & 4985.9 & 1 \\ 69 & 69 & 267763.3 & 668899.7 & 4986.0 & 1 \\ 70 & 70 & 267763.3 & 668899.7 & 4986.0 & 1 \\ 71 & 71 & 266968.4 & 669181.8 & 4986.0 & 1 \\ 72 & 72 & 267822.7 & 668896.6 & 4986.0 & 1 \\ 73 & 73 & 268063.1 & 669204.2 & 4986.0 & 1 \\ 74 & 74 & 267953.9 & 669068.1 & 4986.1 & 1 \\ 75 & 75 & 267057.4 & 669160.9 & 4986.2 & 1 \\ 76 & 76 & 267597.8 & 669149.4 & 4986.2 & 1 \\ 77 & 77 & 267345.0 & 669189.7 & 4986.2 & 1 \\ 78 & 78 & 267468.5 & 669006.9 & 4986.2 & 1 \\ 79 & 79 & 267438.5 & 669008.6 & 4986.2 & 1 \\ 80 & 80 & 268096.1 & 669305.8 & 4986.2 & 1 \\ 81 & 81 & 267329.5 & 669190.3 & 4986.3 & 1 \\ 82 & 82 & 267373.9 & 669172.8 & 4986.3 & 1 \\ 83 & 83 & 267406.8 & 668980.9 & 4986.3 & 1 \\ 84 & 84 & 267926.9 & 669130.4 & 4986.4 & 1 \\ 85 & 85 & 267925.3 & 669100.5 & 4986.4 & 1 \\ 86 & 86 & 268016.3 & 669061.8 & 4986.4 & 1 \\ 87 & 87 & 267411.7 & 669065.1 & 4986.5 & 1 \\ 88 & 88 & 267466.7 & 668977.8 & 4986.5 & 1 \\ 89 & 89 & 267481.1 & 668961.4 & 4986.5 & 1 \\ 90 & 90 & 267965.2 & 669248.6 & 4986.6 & 1 \\ 91 & 91 & 267043.5 & 668864.6 & 4986.7 & 1 \\ 92 & 92 & 267297.2 & 669147.8 & 4986.7 & 1 \\ 93 & 93 & 267386.1 & 669126.6 & 4986.7 & 1 \\ 94 & 94 & 267473.8 & 669091.9 & 4986.7 & 1 \\ 95 & 95 & 267496.5 & 668975.6 & 4986.7 & 1 \\ 96 & 96 & 266969.3 & 669196.6 & 4986.8 & 1 \\ 97 & 97 & 267835.8 & 669105.3 & 4986.8 & 1\end{array}$



Number $\underset{\text { ID }}{\text { Map Easting Northing Basalt Ref } \begin{array}{c}\text { MP } \\ \text { Elevation }\end{array} \text { Elev. Bepth }}$ Below

$\begin{array}{rrrlll}98 & 98 & 267314.3 & 669176.5 & 4986.8 & 1 \\ 99 & 99 & 267428.3 & 669094.5 & 4986.8 & 1 \\ 100 & 100 & 266868.2 & 669027.7 & 4986.9 & 1 \\ 101 & 101 & 267375.2 & 669188.2 & 4986.9 & 1 \\ 102 & 102 & 267579.8 & 668850.2 & 4986.9 & 1 \\ 103 & 103 & 267867.5 & 668653.3 & 4986.9 & 1 \\ 104 & 104 & 267315.2 & 669191.7 & 4987.0 & 1 \\ 105 & 105 & 267293.6 & 669102.8 & 4987.1 & 1 \\ 106 & 106 & 267440.5 & 669038.7 & 4987.1 & 1 \\ 107 & 107 & 267590.3 & 669029.8 & 4987.1 & 1 \\ 108 & 108 & 267959.6 & 668890.9 & 4987.1 & 1 \\ 109 & 109 & 267308.5 & 669102.0 & 4987.2 & 1 \\ 110 & 110 & 267740.7 & 668539.7 & 4987.2 & 1 \\ 111 & 111 & 267897.8 & 669132.0 & 4987.2 & 1 \\ 112 & 112 & 268081.8 & 669261.9 & 4987.2 & 1 \\ 113 & 113 & 267452.6 & 668993.8 & 4987.3 & 1 \\ 114 & 114 & 268088.4 & 669300.9 & 4987.3 & 1 \\ 115 & 115 & 267800.7 & 668535.9 & 4987.5 & 1 \\ 116 & 116 & 266781.9 & 669092.9 & 4987.5 & 1 \\ 117 & 117 & 267299.0 & 669177.6 & 4987.5 & 1 \\ 118 & 118 & 267298.0 & 669161.9 & 4987.5 & 1 \\ 119 & 119 & 267447.0 & 669138.6 & 4987.5 & 1 \\ 120 & 120 & 267514.3 & 669019.4 & 4987.6 & 1 \\ 121 & 121 & 267901.2 & 669192.1 & 4987.6 & 1 \\ 122 & 122 & 267875.1 & 668634.6 & 4987.6 & 1 \\ 123 & 123 & 267029.5 & 668870.1 & 4987.7 & 1 \\ 124 & 124 & 267896.0 & 669102.1 & 4987.7 & 1 \\ 125 & 125 & 267932.5 & 668506.2 & 4987.7 & 1 \\ 126 & 126 & 267057.4 & 668859.6 & 4987.8 & 1 \\ 127 & 127 & 267343.0 & 669159.3 & 4987.8 & 1 \\ 128 & 128 & 267477.4 & 669136.4 & 4987.8 & 1 \\ 129 & 129 & 267461.3 & 669122.8 & 4987.8 & 1 \\ 130 & 130 & 267454.4 & 669022.8 & 4987.8 & 1 \\ 131 & 131 & 267870.3 & 668620.3 & 4987.8 & 1 \\ 132 & 132 & 266953.8 & 669182.8 & 4987.9 & 1 \\ 133 & 133 & 267001.1 & 668880.2 & 4987.9 & 1 \\ 134 & 134 & 267313.5 & 669161.3 & 4987.9 & 1 \\ 135 & 135 & 267312.4 & 669146.2 & 4987.9 & 1 \\ 136 & 136 & 267401.3 & 669126.3 & 4987.9 & 1 \\ 137 & 137 & 267371.0 & 669127.8 & 4987.9 & 1 \\ 138 & 138 & 266706.4 & 669005.9 & 4988.1 & 1 \\ 139 & 139 & 267327.2 & 669145.9 & 4988.1 & 1 \\ 140 & 140 & 267833.9 & 669075.1 & 4988.2 & 1 \\ 141 & 141 & 267398.7 & 669096.6 & 4988.2 & 1 \\ 146 & 142 & 267413.9 & 669095.9 & 4988.2 & 1 \\ 143 & 143 & 267464.8 & 668947.4 & 4988.2 & 1 \\ 144 & 144 & 267833.4 & 669075.8 & 4988.2 & 1 \\ 145 & 145 & 266677.7 & 669113.7 & 4988.3 & 1 \\ 146 & 146 & 267402.4 & 669141.3 & 4988.3 & 1 \\ & & & & & \end{array}$

$$
\text { A-5 }
$$




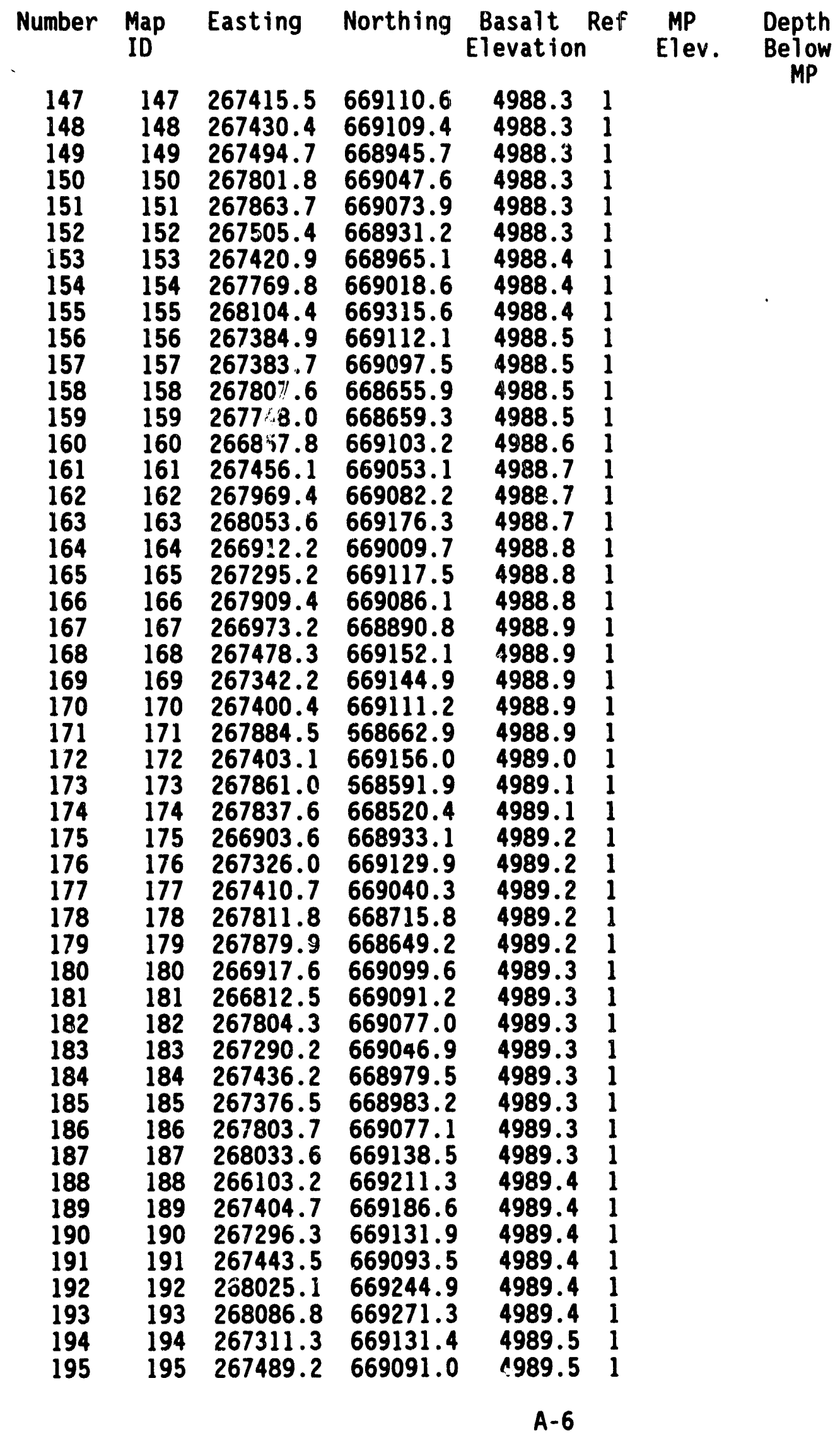




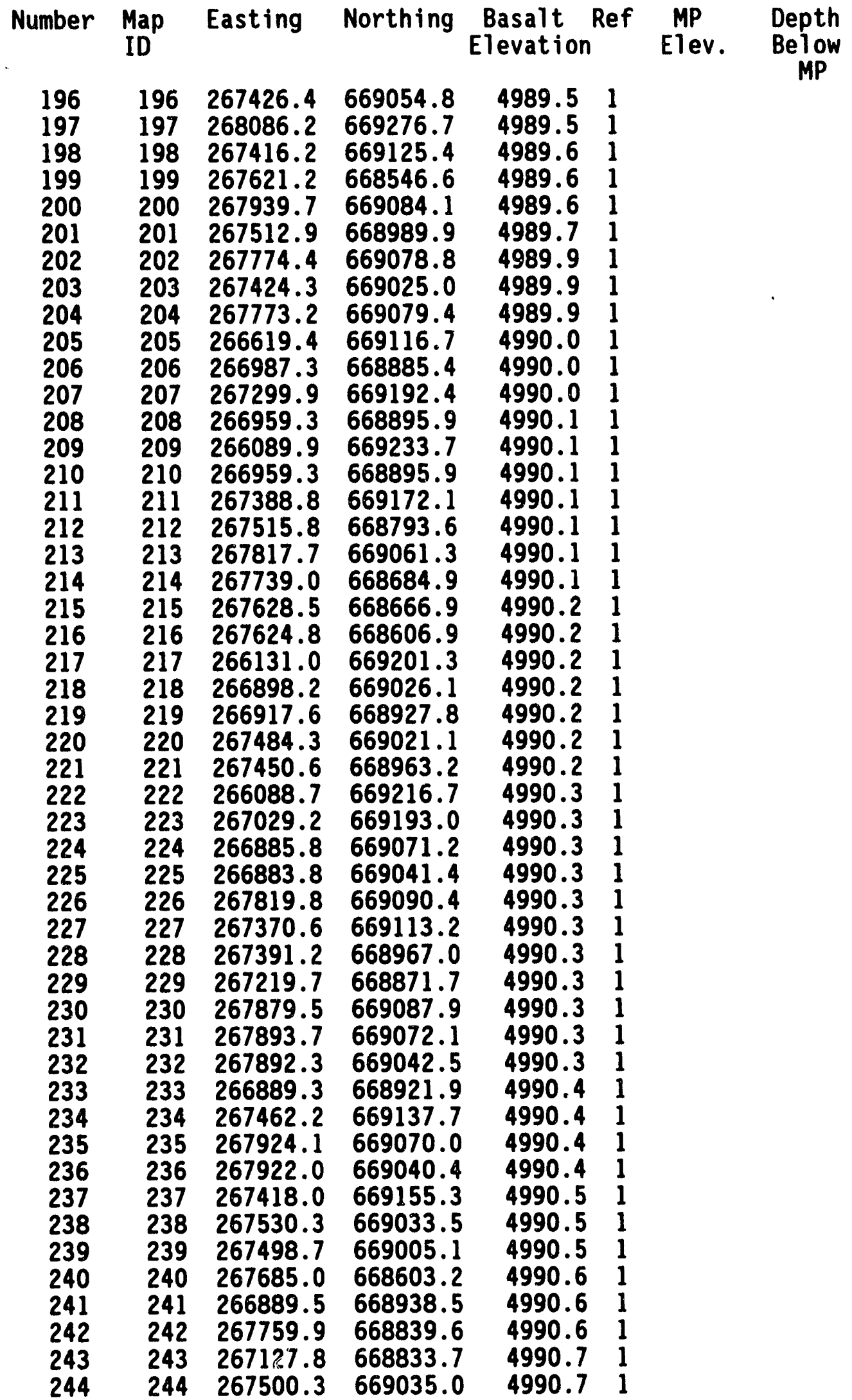

$$
\text { A-7 }
$$




\begin{tabular}{|c|c|c|c|c|c|c|c|}
\hline Number & $\begin{array}{l}\text { Map } \\
\text { ID }\end{array}$ & Easting & Northing & $\begin{array}{l}\text { Basalt } \\
\text { Elevation }\end{array}$ & Ref & $\begin{array}{c}\text { MP } \\
\text { Elev. }\end{array}$ & $\begin{array}{l}\text { Depth } \\
\text { Below }\end{array}$ \\
\hline $\begin{array}{l}245 \\
246 \\
247 \\
248 \\
249 \\
250 \\
251 \\
252 \\
253 \\
254 \\
255 \\
256 \\
257 \\
258 \\
259 \\
260 \\
261 \\
262 \\
263 \\
264 \\
265 \\
266 \\
267 \\
268 \\
269 \\
270 \\
271 \\
272 \\
273 \\
274 \\
275 \\
276 \\
277 \\
278 \\
279 \\
280 \\
281 \\
282 \\
283 \\
284 \\
285 \\
286 \\
287 \\
288 \\
289 \\
290 \\
291 \\
292 \\
293\end{array}$ & $\begin{array}{l}245 \\
246 \\
247 \\
248 \\
249 \\
250 \\
251 \\
252 \\
253 \\
254 \\
255 \\
256 \\
257 \\
258 \\
259 \\
260 \\
261 \\
262 \\
263 \\
264 \\
265 \\
266 \\
267 \\
268 \\
269 \\
270 \\
271 \\
272 \\
273 \\
274 \\
275 \\
276 \\
277 \\
278 \\
279 \\
280 \\
281 \\
282 \\
283 \\
284 \\
285 \\
286 \\
287 \\
288 \\
289 \\
290 \\
291 \\
292 \\
293\end{array}$ & $\begin{array}{l}267787.6 \\
267128.9 \\
267404.6 \\
266984.4 \\
26871.9 \\
266874.3 \\
267460.4 \\
267445.3 \\
267955.0 \\
266132.3 \\
267507.9 \\
267417.2 \\
267262.2 \\
267291.7 \\
267320.5 \\
267848.3 \\
267431.1 \\
267355.2 \\
267458.6 \\
267815.8 \\
267444.6 \\
267844.6 \\
267404.2 \\
267523.1 \\
267447.7 \\
267310.3 \\
267350.4 \\
267375.3 \\
267446.2 \\
267356.0 \\
267459.4 \\
268028.7 \\
266116.9 \\
266999.1 \\
266722.1 \\
267419.2 \\
267493.2 \\
267323.5 \\
267015.3 \\
267837.6 \\
267508.9 \\
267341.1 \\
267434.6 \\
267681.9 \\
266144.7 \\
267396.4 \\
267422.7 \\
267729.7 \\
267419.9\end{array}$ & $\begin{array}{l}669063.3 \\
668850.4 \\
668950.9 \\
669195.3 \\
669087.8 \\
668927.1 \\
669107.8 \\
669108.3 \\
668876.4 \\
669217.9 \\
669150.0 \\
669140.4 \\
669074.7 \\
669072.3 \\
669045.7 \\
669314.8 \\
669124.5 \\
669113.8 \\
669092.7 \\
668775.9 \\
668617.4 \\
669254.8 \\
669171.5 \\
669149.1 \\
669153.8 \\
669116.4 \\
669043.8 \\
668952.6 \\
669123.4 \\
669128.6 \\
668857.1 \\
669304.9 \\
669206.6 \\
669194.6 \\
669096.9 \\
669170.5 \\
669150.8 \\
669101.1 \\
668875.2 \\
669134.7 \\
669165.1 \\
669129.4 \\
668949.3 \\
669054.6 \\
669195.7 \\
669056.4 \\
668995.4 \\
668648.5 \\
669185.9\end{array}$ & $\begin{array}{l}4990.7 \\
4990.8 \\
4990.8 \\
4990.9 \\
4990.9 \\
4990.9 \\
4990.9 \\
4991.0 \\
4991.0 \\
4991.1 \\
4991.1 \\
4991.1 \\
4991.2 \\
4991.2 \\
4991.2 \\
4991.3 \\
4991.3 \\
4991.3 \\
4991.3 \\
4991.3 \\
4991.4 \\
4991.4 \\
4991.4 \\
4991.4 \\
4991.4 \\
4991.4 \\
4991.4 \\
4991.4 \\
4991.5 \\
4991.5 \\
4991.5 \\
4991.5 \\
4991.6 \\
4991.6 \\
4991.6 \\
4991.6 \\
4991.7 \\
4991.7 \\
4991.8 \\
4991.8 \\
4991.8 \\
4991.8 \\
4991.8 \\
4991.8 \\
4991.9 \\
4991.9 \\
4991.9 \\
4991.9 \\
4992.0\end{array}$ & $\begin{array}{l}1 \\
1 \\
1 \\
1 \\
1 \\
1 \\
1 \\
1 \\
1 \\
1 \\
1 \\
1 \\
1 \\
1 \\
1 \\
1 \\
1 \\
1 \\
1 \\
1 \\
1 \\
1 \\
1 \\
1 \\
1 \\
1 \\
1 \\
1 \\
1 \\
1 \\
1 \\
1 \\
1 \\
1 \\
1 \\
1 \\
1 \\
1 \\
1 \\
1 \\
1 \\
1 \\
1 \\
1 \\
1\end{array}$ & & . \\
\hline & & & & A-8 & & & \\
\hline
\end{tabular}




$\begin{array}{cccccc}\text { Number } & \text { Map } & \text { Easting } & \text { Northing } & \begin{array}{c}\text { Basalt } \\ \text { Elevation }\end{array} & \text { Ref } \\ & \text { ID } & & & & \\ 294 & 294 & 267389.6 & 669187.6 & 4992.0 & 1 \\ 295 & 295 & 267681.0 & 668543.2 & 4992.0 & 1 \\ 296 & 296 & 267968.7 & 669309.0 & 4992.0 & 1 \\ 297 & 297 & 267849.3 & 669089.8 & 4992.0 & 1 \\ 298 & 298 & 267983.9 & 669066.3 & 4992.0 & 1 \\ 299 & 299 & 268039.4 & 669133.3 & 4992.0 & 1 \\ 300 & 300 & 267014.8 & 669193.8 & 4992.1 & 1 \\ 301 & 301 & 267058.8 & 668876.1 & 4992.1 & 1 \\ 302 & 302 & 267276.1 & 669063.6 & 4992.1 & 1 \\ 303 & 303 & 268048.9 & 669161.7 & 4992.1 & 1 \\ 304 & 304 & 266523.3 & 669055.1 & 4992.2 & 1 \\ 305 & 305 & 267043.5 & 669177.3 & 4992.2 & 1 \\ 306 & 306 & 267058.2 & 669176.5 & 4992.2 & 1 \\ 307 & 307 & 267394.5 & 669026.7 & 4992.2 & 1 \\ 308 & 308 & 267392.6 & 668996.8 & 4992.2 & 1 \\ 309 & 309 & 267523.2 & 668913.9 & 4992.3 & 1 \\ 310 & 310 & 267044.2 & 669191.9 & 4992.4 & 1 \\ 311 & 311 & 267169.1 & 669184.3 & 4992.4 & 1 \\ 312 & 312 & 267113.3 & 668838.9 & 4992.4 & 1 \\ 313 & 313 & 267781.1 & 669198.8 & 4992.4 & 1 \\ 314 & 314 & 267524.2 & 669164.4 & 4992.4 & 1 \\ 315 & 315 & 267432.0 & 669139.8 & 4992.4 & 1 \\ 316 & 316 & 267507.1 & 669134.9 & 4992.4 & 1 \\ 317 & 317 & 267381.0 & 669041.7 & 4992.4 & 1 \\ 318 & 318 & 267856.7 & 668577.6 & 4992.4 & 1 \\ 319 & 319 & 267568.2 & 668670.6 & 4992.5 & 1 \\ 320 & 320 & 266951.6 & 669153.2 & 4992.5 & 1 \\ 321 & 321 & 266974.4 & 668907.2 & 4992.5 & 1 \\ 322 & 322 & 267650.4 & 669026.0 & 4992.5 & 1 \\ 323 & 323 & 267908.1 & 669312.7 & 4992.5 & 1 \\ 324 & 324 & 267044.4 & 668881.3 & 4992.6 & 1 \\ 325 & 325 & 267408.3 & 669010.6 & 4992.6 & 1 \\ 326 & 326 & 267973.1 & 668933.6 & 4992.6 & 1 \\ 327 & 327 & 267504.7 & 668614.1 & 4992.7 & 1 \\ 328 & 328 & 266899.9 & 669055.9 & 4992.7 & 1 \\ 329 & 329 & 267071.5 & 668854.1 & 4992.7 & 1 \\ 330 & 330 & 267744.8 & 668599.5 & 4992.8 & 1 \\ 331 & 331 & 266104.2 & 669228.8 & 4992.8 & 1 \\ 332 & 332 & 267340.6 & 669115.0 & 4992.8 & 1 \\ 333 & 333 & 267364.8 & 669028.3 & 4992.8 & 1 \\ 334 & 334 & 266158.9 & 669190.8 & 4992.9 & 1 \\ 335 & 335 & 267042.7 & 669162.4 & 4992.9 & 1 \\ 336 & 336 & 267353.9 & 669099.1 & 4992.9 & 1 \\ 337 & 337 & 267905.0 & 669252.4 & 4992.9 & 1 \\ 338 & 338 & 267030.5 & 668886.7 & 4993.0 & 1 \\ 339 & 339 & 267832.7 & 669060.6 & 4993.0 & 1 \\ 340 & 340 & 267847.3 & 669059.4 & 4993.0 & 1 \\ 341 & 341 & 267992.0 & 668991.2 & 4993.0 & 1 \\ 342 & 342 & 267028.3 & 669178.4 & 4993.1 & 1 \\ & & & & & \end{array}$




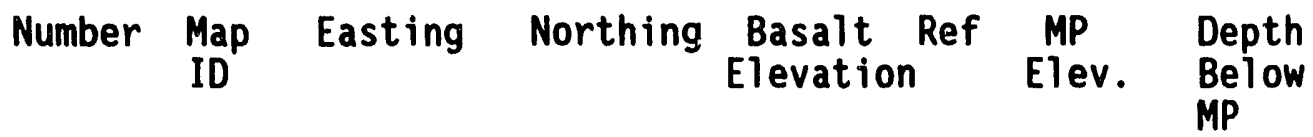

$\begin{array}{llllll}343 & 343 & 266692.8 & 669010.7 & 4993.1 & 1 \\ 344 & 344 & 267072.5 & 668871.1 & 4993.1 & 1 \\ 345 & 345 & 267086.0 & 668848.9 & 4993.1 & 1 \\ 346 & 346 & 267482.7 & 668991.8 & 4993.1 & 1 \\ 347 & 347 & 267343.1 & 668924.5 & 4993.1 & 1 \\ 348 & 348 & 267451.7 & 668738.0 & 4993.1 & 1 \\ 349 & 349 & 267027.2 & 669163.3 & 4993.2 & 1 \\ 350 & 350 & 267712.1 & 669052.6 & 4993.2 & 1 \\ 351 & 351 & 267968.8 & 669067.7 & 4993.2 & 1 \\ 352 & 352 & 267968.0 & 669051.8 & 4993.2 & 1 \\ 353 & 353 & 267828.0 & 668492.6 & 4993.2 & 1 \\ 354 & 354 & 267114.8 & 668855.7 & 4993.3 & 1 \\ 355 & 355 & 266983.5 & 669180.9 & 4993.3 & 1 \\ 356 & 356 & 266887.0 & 669101.5 & 4993.3 & 1 \\ 357 & 357 & 267114.6 & 668855.3 & 4993.3 & 1 \\ 358 & 358 & 267325.4 & 669115.8 & 4993.3 & 1 \\ 359 & 359 & 267741.4 & 669051.5 & 4993.3 & 1 \\ 360 & 360 & 267866.8 & 669134.1 & 4993.3 & 1 \\ 361 & 361 & 267789.8 & 669092.2 & 4993.4 & 1 \\ 362 & 362 & 267274.5 & 669034.0 & 4993.4 & 1 \\ 363 & 363 & 268006.1 & 669033.8 & 4993.4 & 1 \\ 364 & 364 & 266173.3 & 669185.4 & 4993.5 & 1 \\ 365 & 365 & 267369.0 & 669097.9 & 4993.5 & 1 \\ 366 & 366 & 267378.7 & 669012.1 & 4993.5 & 1 \\ 367 & 367 & 267511.5 & 668734.3 & 4993.5 & 1 \\ 368 & 368 & 267998.6 & 669065.9 & 4993.5 & 1 \\ 369 & 369 & 267997.9 & 669050.4 & 4993.5 & 1 \\ 370 & 370 & 266901.7 & 669086.1 & 4993.6 & 1 \\ 371 & 371 & 267345.1 & 668954.8 & 4993.6 & 1 \\ 372 & 372 & 267586.8 & 668970.1 & 4993.6 & 1 \\ 373 & 373 & 266368.1 & 669130.4 & 4993.7 & 1 \\ 374 & 374 & 267193.8 & 669183.1 & 4993.7 & 1 \\ 375 & 375 & 267178.1 & 669169.1 & 4993.7 & 1 \\ 376 & 376 & 267492.2 & 669135.9 & 4993.7 & 1 \\ 377 & 377 & 267475.8 & 669106.8 & 4993.7 & 1 \\ 378 & 378 & 267304.8 & 669031.9 & 4993.7 & 1 \\ 379 & 379 & 267528.1 & 669003.4 & 4993.8 & 1 \\ 380 & 380 & 267134.5 & 669186.2 & 4993.8 & 1 \\ 381 & 381 & 267149.1 & 669185.4 & 4993.8 & 1 \\ 382 & 382 & 267177.0 & 669154.0 & 4993.8 & 1 \\ 383 & 383 & 267016.3 & 668891.8 & 4993.8 & 1 \\ 384 & 384 & 266902.8 & 668916.6 & 4993.8 & 1 \\ 385 & 385 & 267099.7 & 668844.1 & 4993.8 & 1 \\ 386 & 386 & 267246.6 & 669065.5 & 4993.8 & 1 \\ 387 & 387 & 267334.5 & 669030.4 & 4993.8 & 1 \\ 388 & 388 & 267242.8 & 669005.9 & 4993.8 & 1 \\ 389 & 389 & 268011.8 & 669035.2 & 4993.8 & 1 \\ 390 & 390 & 266188.3 & 669197.6 & 4993.9 & 1 \\ & & & & & \end{array}$




\begin{tabular}{|c|c|c|c|c|c|c|c|}
\hline Number & $\begin{array}{l}\text { Map } \\
\text { ID }\end{array}$ & Easting & Northing & $\begin{array}{l}\text { Basalt } \\
\text { levation }\end{array}$ & $\operatorname{Ref}$ & $\begin{array}{l}\text { MP } \\
\text { Elev. }\end{array}$ & $\begin{array}{l}\text { Depth } \\
\text { Below }\end{array}$ \\
\hline $\begin{array}{l}391 \\
392 \\
393 \\
394 \\
395 \\
396 \\
397 \\
398 \\
399 \\
400 \\
401 \\
402 \\
403 \\
404 \\
405 \\
406 \\
407 \\
408 \\
409 \\
410 \\
411 \\
412 \\
413 \\
414 \\
415 \\
416 \\
417 \\
418 \\
419 \\
420 \\
421 \\
422 \\
423 \\
424 \\
425 \\
426 \\
427 \\
428 \\
429 \\
430 \\
431 \\
432 \\
433 \\
434 \\
435 \\
436 \\
437 \\
438 \\
439\end{array}$ & $\begin{array}{l}391 \\
392 \\
393 \\
394 \\
395 \\
396 \\
397 \\
398 \\
399 \\
400 \\
401 \\
402 \\
403 \\
404 \\
405 \\
406 \\
407 \\
408 \\
409 \\
410 \\
411 \\
412 \\
413 \\
414 \\
415 \\
416 \\
417 \\
418 \\
419 \\
420 \\
421 \\
422 \\
423 \\
424 \\
425 \\
426 \\
427 \\
428 \\
429 \\
430 \\
431 \\
432 \\
433 \\
434 \\
435 \\
436 \\
437 \\
438 \\
439\end{array}$ & $\begin{array}{l}267014.0 \\
267163.3 \\
267059.1 \\
266795.6 \\
267223.1 \\
267757.6 \\
267104.5 \\
266998.3 \\
267073.5 \\
266997.2 \\
266664.6 \\
266988.2 \\
26696.9 \\
266944.8 \\
267476.1 \\
267486.3 \\
267969.0 \\
266466.5 \\
267119.2 \\
267012.7 \\
266932.1 \\
267002.3 \\
267382.1 \\
267244.4 \\
266767.8 \\
266947.3 \\
268044.4 \\
266496.4 \\
266967.0 \\
266931.6 \\
266914.2 \\
266650.2 \\
267788.6 \\
267831.6 \\
267583.2 \\
267997.1 \\
266481.8 \\
266509.8 \\
267148.2 \\
267041.4 \\
266649.4 \\
267572.1 \\
268048.8 \\
267988.2 \\
267871.6 \\
267723.0 \\
267447.8 \\
266552.6 \\
267103.8\end{array}$ & $\begin{array}{l}669178.9 \\
669170.1 \\
669190.6 \\
669076.7 \\
668931.4 \\
669065.2 \\
669188.1 \\
669180.1 \\
669175.3 \\
669165.1 \\
669021.6 \\
668902.1 \\
668911.8 \\
668901.4 \\
669121.8 \\
669050.9 \\
668919.1 \\
669076.6 \\
669187.3 \\
669164.2 \\
668922.7 \\
668897.2 \\
669067.1 \\
669035.7 \\
669108.5 \\
669097.6 \\
669147.4 \\
669082.9 \\
669151.9 \\
669083.9 \\
669039.7 \\
669026.4 \\
669318.4 \\
669045.8 \\
668909.9 \\
669005.1 \\
669088.3 \\
669078.0 \\
669170.7 \\
669147.7 \\
669010.2 \\
668730.3 \\
669152.6 \\
668976.7 \\
668712.9 \\
668617.9 \\
668677.4 \\
669061.9 \\
669173.4\end{array}$ & $\begin{array}{l}4993.9 \\
4993.9 \\
4994.0 \\
4994.0 \\
4994.0 \\
4994.0 \\
4994.1 \\
4994.1 \\
4994.1 \\
4994.1 \\
4994.1 \\
4994.1 \\
4994.1 \\
4994.1 \\
4994.1 \\
4994.1 \\
4994.1 \\
4994.2 \\
4994.2 \\
4994.2 \\
4994.2 \\
4994.2 \\
4994.2 \\
4994.2 \\
4994.3 \\
4994.3 \\
4994.3 \\
4994.4 \\
4994.4 \\
4994.4 \\
4994.4 \\
4994.4 \\
4994.4 \\
4994.4 \\
4994.4 \\
4994.4 \\
4994.5 \\
4994.5 \\
4994.5 \\
4994.5 \\
4994.5 \\
4994.5 \\
4994.5 \\
4994.5 \\
4994.5 \\
4994.5 \\
4994.6 \\
4994.6 \\
4994.6\end{array}$ & $\begin{array}{l}1 \\
1 \\
1 \\
1 \\
1 \\
1 \\
1 \\
1 \\
1 \\
1 \\
1 \\
1 \\
1 \\
1 \\
1 \\
1 \\
1 \\
1 \\
1 \\
1 \\
1 \\
1 \\
1 \\
1 \\
1 \\
1 \\
1 \\
1 \\
1 \\
1 \\
1 \\
1 \\
1 \\
1 \\
1 \\
1 \\
1 \\
1 \\
1 \\
1 \\
1 \\
1 \\
1 \\
1 \\
1 \\
1 \\
1 \\
1 \\
1\end{array}$ & & . \\
\hline
\end{tabular}




\begin{tabular}{|c|c|c|c|c|c|c|c|}
\hline Number & $\begin{array}{l}\text { Map } \\
\text { ID }\end{array}$ & Easting & Northing & $\begin{array}{l}\text { Basalt } \\
\text { Elevation }\end{array}$ & $\operatorname{Ref}$ & $\begin{array}{l}\text { MP } \\
\text { Elev. }\end{array}$ & $\begin{array}{l}\text { Depth } \\
\text { Below }\end{array}$ \\
\hline $\begin{array}{l}440 \\
441 \\
442 \\
443 \\
444 \\
445 \\
446 \\
447 \\
448 \\
449 \\
450 \\
451 \\
452 \\
453 \\
454 \\
455 \\
456 \\
457 \\
458 \\
459 \\
460 \\
461 \\
462 \\
463 \\
464 \\
465 \\
466 \\
467 \\
468 \\
469 \\
470 \\
471 \\
472 \\
473 \\
474 \\
475 \\
476 \\
477 \\
478 \\
479 \\
480 \\
481 \\
482 \\
483 \\
484 \\
485 \\
486 \\
487 \\
488\end{array}$ & $\begin{array}{l}440 \\
441 \\
442 \\
443 \\
444 \\
445 \\
446 \\
447 \\
448 \\
449 \\
450 \\
451 \\
452 \\
453 \\
454 \\
455 \\
456 \\
457 \\
458 \\
459 \\
460 \\
461 \\
462 \\
463 \\
464 \\
465 \\
466 \\
467 \\
468 \\
469 \\
470 \\
471 \\
472 \\
473 \\
474 \\
475 \\
476 \\
477 \\
478 \\
479 \\
480 \\
481 \\
482 \\
483 \\
484 \\
485 \\
486 \\
487 \\
488\end{array}$ & $\begin{array}{l}266647.5 \\
266945.0 \\
267432.7 \\
267396.7 \\
267072.0 \\
266960.3 \\
267101.1 \\
267852.0 \\
267804.3 \\
266117.8 \\
266982.8 \\
266707.7 \\
267331.6 \\
266580.7 \\
266537.3 \\
267074.3 \\
267089.5 \\
266928.2 \\
267142.5 \\
267552.8 \\
267241.0 \\
266202.5 \\
267026.6 \\
266961.7 \\
266942.2 \\
266636.3 \\
266875.2 \\
266635.6 \\
267339.0 \\
267321.9 \\
267953.9 \\
267952.3 \\
267514.8 \\
266915.8 \\
266930.0 \\
267086.7 \\
267257.1 \\
267846.7 \\
266187.1 \\
267118.1 \\
267133.6 \\
267147.2 \\
266766.0 \\
266823.8 \\
267829.8 \\
266452.5 \\
266579.6 \\
267088.5 \\
267162.3\end{array}$ & $\begin{array}{l}669115.7 \\
669067.9 \\
669154.4 \\
668800.9 \\
669145.9 \\
668912.5 \\
668860.9 \\
668563.0 \\
668596.0 \\
669223.4 \\
669166.1 \\
669111.9 \\
668744.9 \\
669051.6 \\
669049.9 \\
669190.1 \\
669188.8 \\
669024.4 \\
668844.8 \\
669147.4 \\
668975.4 \\
669192.2 \\
669148.2 \\
669082.5 \\
669007.9 \\
669031.8 \\
668943.3 \\
669015.1 \\
669099.8 \\
669070.8 \\
669068.1 \\
669038.6 \\
668960.4 \\
669069.6 \\
669054.2 \\
668865.7 \\
668990.0 \\
668548.9 \\
669180.4 \\
669172.7 \\
669171.8 \\
669156.1 \\
669078.6 \\
669044.9 \\
669015.4 \\
669081.7 \\
669034.3 \\
669174.6 \\
669155.1\end{array}$ & $\begin{array}{l}4994.6 \\
4994.6 \\
4994.6 \\
4994.6 \\
4994.7 \\
4994.7 \\
4994.7 \\
4994.7 \\
4994.8 \\
4994.8 \\
4994.8 \\
4994.8 \\
4994.8 \\
4994.9 \\
4994.9 \\
4994.9 \\
4994.9 \\
4994.9 \\
4994.9 \\
4994.9 \\
4994.9 \\
4995.0 \\
4995.0 \\
4995.0 \\
4995.0 \\
4955.0 \\
4995.0 \\
4995.0 \\
4995.0 \\
4995.0 \\
4995.0 \\
4995.0 \\
4995.0 \\
4995.1 \\
4995.1 \\
4995.1 \\
4995.1 \\
4995.1 \\
4995.2 \\
4995.2 \\
4995.2 \\
4995.2 \\
4995.2 \\
4995.2 \\
4995.2 \\
4995.3 \\
4995.3 \\
4995.3 \\
4995.3\end{array}$ & $\begin{array}{l}1 \\
1 \\
1 \\
1 \\
1 \\
1 \\
1 \\
1 \\
1 \\
1 \\
1 \\
1 \\
1 \\
1 \\
1 \\
1 \\
1 \\
1 \\
1 \\
1 \\
1 \\
1 \\
1 \\
1 \\
1 \\
1 \\
1 \\
1 \\
1 \\
1 \\
1 \\
1 \\
1 \\
1 \\
1 \\
1 \\
1 \\
1 \\
1 \\
1 \\
1 \\
1 \\
1 \\
1 \\
1 \\
1 \\
1 \\
1 \\
1\end{array}$ & & . \\
\hline
\end{tabular}




\begin{tabular}{|c|c|c|c|c|c|c|c|}
\hline Number & $\operatorname{Map}_{\text {ID }}$ & Easting & Northing & $\begin{array}{l}\text { Basalt } \\
\text { Elevation }\end{array}$ & Ref & $\begin{array}{l}\text { MP } \\
\text { Elev. }\end{array}$ & $\begin{array}{l}\text { Depth } \\
\text { Below }\end{array}$ \\
\hline $\begin{array}{l}489 \\
490 \\
491 \\
492 \\
493 \\
494 \\
495 \\
496 \\
497 \\
498 \\
499 \\
500 \\
501 \\
502 \\
503 \\
504 \\
505 \\
506 \\
507 \\
508 \\
509 \\
510 \\
511 \\
512 \\
513 \\
514 \\
515 \\
516 \\
517 \\
518 \\
519 \\
520 \\
521 \\
522 \\
523 \\
524 \\
525 \\
526 \\
527 \\
528 \\
529 \\
530 \\
531 \\
532 \\
533 \\
534 \\
535 \\
536 \\
537\end{array}$ & $\begin{array}{l}489 \\
490 \\
491 \\
492 \\
493 \\
494 \\
495 \\
496 \\
497 \\
498 \\
499 \\
500 \\
501 \\
502 \\
503 \\
504 \\
505 \\
506 \\
507 \\
508 \\
509 \\
510 \\
511 \\
512 \\
513 \\
514 \\
515 \\
516 \\
517 \\
518 \\
519 \\
520 \\
521 \\
522 \\
523 \\
524 \\
525 \\
526 \\
527 \\
528 \\
529 \\
530 \\
531 \\
532 \\
533 \\
534 \\
535 \\
536 \\
537\end{array}$ & $\begin{array}{l}266946.2 \\
268001.7 \\
267889.5 \\
266480.7 \\
267056.5 \\
267101.3 \\
266720.5 \\
266860.7 \\
267306.3 \\
267404.0 \\
266453.5 \\
266538.4 \\
266566.3 \\
267117.2 \\
266662.0 \\
267538.0 \\
267444.9 \\
266981.7 \\
266996.7 \\
267012.1 \\
267539.8 \\
267086.8 \\
267116.6 \\
267131.6 \\
266736.2 \\
266956.8 \\
267978.2 \\
266467.9 \\
267102.3 \\
267132.4 \\
267161.0 \\
267471.9 \\
267983.9 \\
267981.5 \\
266958.1 \\
266439.5 \\
266494.4 \\
267176.2 \\
267950.5 \\
267983.0 \\
266567.0 \\
266509.0 \\
267433.7 \\
267228.8 \\
267339.3 \\
266382.7 \\
266438.3 \\
266960.0 \\
267841.1\end{array}$ & $\begin{array}{l}668917.6 \\
669019.6 \\
668676.7 \\
669070.8 \\
669146.5 \\
669143.9 \\
669000.4 \\
668932.1 \\
669061.9 \\
668920.9 \\
669098.9 \\
669067.3 \\
669039.8 \\
669157.6 \\
669100.2 \\
669148.1 \\
668753.6 \\
669151.4 \\
669149.9 \\
669149.3 \\
669178.2 \\
669144.8 \\
669142.9 \\
669142.3 \\
669080.1 \\
668991.9 \\
668948.1 \\
669093.4 \\
669158.6 \\
669156.4 \\
669139.9 \\
669061.6 \\
669066.3 \\
669036.6 \\
669022.1 \\
669104.3 \\
669065.7 \\
669139.3 \\
668862.4 \\
668962.6 \\
669056.8 \\
669060.4 \\
669169.5 \\
669021.6 \\
668864.3 \\
669125.6 \\
669087.0 \\
669052.2 \\
669194.9\end{array}$ & $\begin{array}{l}4995.3 \\
4995.3 \\
4995.3 \\
4995.4 \\
4995.4 \\
4995.4 \\
4995.4 \\
4995.4 \\
4995.4 \\
4995.4 \\
4995.5 \\
4995.5 \\
4995.5 \\
4995.5 \\
4995.5 \\
4995.5 \\
4995.5 \\
4995.6 \\
4995.6 \\
4995.6 \\
4995.6 \\
4995.7 \\
4995.7 \\
4995.7 \\
4995.7 \\
4995.7 \\
4995.7 \\
4995.8 \\
4995.8 \\
4995.8 \\
4995.8 \\
4995.8 \\
4995.8 \\
4995.8 \\
4995.9 \\
4996.0 \\
4996.0 \\
4996.0 \\
4996.0 \\
4996.0 \\
4996.1 \\
4996.1 \\
4996.1 \\
4996.1 \\
4996.1 \\
4996.2 \\
4996.2 \\
4996.2 \\
4996.2\end{array}$ & $\begin{array}{l}1 \\
1 \\
1 \\
1 \\
1 \\
1 \\
1 \\
1 \\
1 \\
1 \\
1 \\
1 \\
1 \\
1 \\
1 \\
1 \\
1 \\
1 \\
1 \\
1 \\
1 \\
1 \\
1 \\
1 \\
1 \\
1 \\
1 \\
1 \\
1 \\
1 \\
1 \\
1 \\
1 \\
1 \\
1 \\
1 \\
1 \\
1 \\
1 \\
1 \\
1 \\
1 \\
1 \\
1 \\
1 \\
1 \\
1 \\
1 \\
1\end{array}$ & & . \\
\hline & & & & A-13 & & & \\
\hline
\end{tabular}




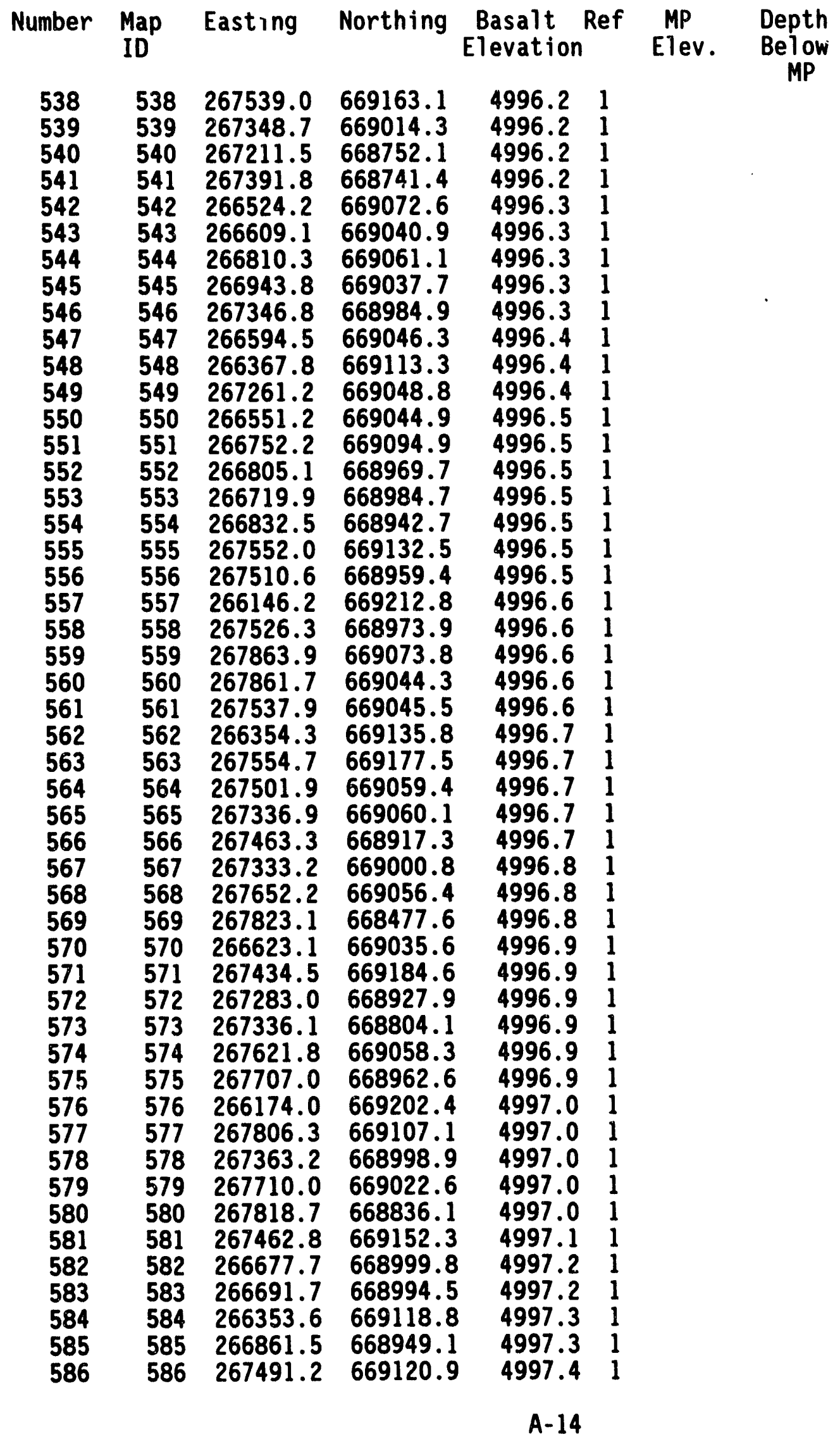




\begin{tabular}{|c|c|c|c|c|c|c|c|}
\hline Number & $\begin{array}{l}\text { Map } \\
\text { ID }\end{array}$ & Easting & Northing & $\begin{array}{l}\text { Basalt } \\
\text { Elevation }\end{array}$ & Ref & $\begin{array}{c}\text { MP } \\
\text { Elev. }\end{array}$ & $\begin{array}{c}\text { Depth } \\
\text { Below } \\
\text { MP }\end{array}$ \\
\hline $\begin{array}{l}587 \\
588 \\
589 \\
590 \\
591 \\
592 \\
593 \\
594 \\
595 \\
596 \\
597 \\
598 \\
599 \\
600 \\
601 \\
602 \\
603 \\
604 \\
605 \\
606 \\
607 \\
608 \\
609 \\
610 \\
611 \\
612 \\
613 \\
614 \\
615 \\
616 \\
617 \\
618 \\
619 \\
620 \\
621 \\
622 \\
623 \\
624 \\
625 \\
626 \\
627 \\
628 \\
629 \\
630 \\
631 \\
632 \\
633 \\
634 \\
635\end{array}$ & $\begin{array}{l}587 \\
588 \\
589 \\
590 \\
591 \\
592 \\
593 \\
594 \\
595 \\
596 \\
597 \\
598 \\
599 \\
600 \\
601 \\
602 \\
603 \\
604 \\
605 \\
606 \\
607 \\
608 \\
609 \\
610 \\
611 \\
612 \\
613 \\
614 \\
615 \\
616 \\
617 \\
618 \\
619 \\
620 \\
621 \\
622 \\
623 \\
624 \\
625 \\
626 \\
627 \\
628 \\
629 \\
630 \\
631 \\
632 \\
633 \\
634 \\
635\end{array}$ & $\begin{array}{l}267591.8 \\
267647.1 \\
267768.9 \\
266705.7 \\
267601.5 \\
267524.7 \\
267522.3 \\
267352.1 \\
267224.6 \\
267894.2 \\
267753.5 \\
266780.3 \\
266339.3 \\
267494.0 \\
267553.9 \\
267366.5 \\
267318.3 \\
266737.5 \\
266734.3 \\
267507.9 \\
266678.6 \\
266663.8 \\
266159.9 \\
266339.9 \\
266593.9 \\
267531.5 \\
267361.0 \\
267945.6 \\
267903.8 \\
267537.2 \\
267808.2 \\
267490.7 \\
267314.7 \\
267879.6 \\
267727.8 \\
267692.3 \\
267875.9 \\
267564.7 \\
267898.8 \\
266201.5 \\
266833.3 \\
267216.1 \\
267503.8 \\
267668.8 \\
266410.8 \\
266804.4 \\
267258.7 \\
266215.5 \\
266215.2\end{array}$ & $\begin{array}{l}669054.6 \\
668966.4 \\
668815.3 \\
668989.6 \\
669209.2 \\
669179.3 \\
669134.1 \\
669068.7 \\
668961.4 \\
668691.9 \\
668738.6 \\
669062.8 \\
669124.3 \\
669165.9 \\
669162.3 \\
669058.4 \\
669016.4 \\
669109.9 \\
668979.3 \\
668673.9 \\
669015.8 \\
669004.7 \\
669207.4 \\
669140.9 \\
669029.0 \\
669058.1 \\
668968.8 \\
668848.3 \\
668720.4 \\
669133.1 \\
669136.1 \\
669105.8 \\
668956.4 \\
668832.3 \\
669067.1 \\
668722.9 \\
668772.6 \\
668610.4 \\
668705.9 \\
669174.8 \\
668959.1 \\
668811.3 \\
669090.2 \\
669325.3 \\
669115.0 \\
668953.2 \\
669019.7 \\
669170.0 \\
669170.1\end{array}$ & $\begin{array}{l}4997.4 \\
4997.4 \\
4997.4 \\
4997.5 \\
4997.5 \\
4997.5 \\
4997.5 \\
4997.5 \\
4997.5 \\
4997.5 \\
4997.5 \\
4997.6 \\
4997.7 \\
4997.7 \\
4997.7 \\
4997.7 \\
4997.7 \\
4997.8 \\
4997.8 \\
4997.9 \\
4997.9 \\
4997.9 \\
4998.0 \\
4998.0 \\
4998.0 \\
4998.0 \\
4998.0 \\
4998.0 \\
4998.0 \\
4998.1 \\
4998.2 \\
4998.2 \\
4998.2 \\
4998.2 \\
4998.3 \\
4998.3 \\
4998.3 \\
4998.5 \\
4998.5 \\
4998.6 \\
4998.6 \\
4998.6 \\
4998.7 \\
4998.8 \\
4998.9 \\
4998.9 \\
4998.9 \\
4999.0 \\
4999.0\end{array}$ & $\begin{array}{l}1 \\
1 \\
1 \\
1 \\
1 \\
1 \\
1 \\
1 \\
1 \\
1 \\
1 \\
1 \\
1 \\
1 \\
1 \\
1 \\
1 \\
1 \\
1 \\
1 \\
1 \\
1 \\
1 \\
1 \\
1 \\
1 \\
1 \\
1 \\
1 \\
1 \\
1 \\
1 \\
1 \\
1 \\
1 \\
1 \\
1 \\
1 \\
1 \\
1 \\
1 \\
1 \\
1 \\
1 \\
1 \\
1 \\
1 \\
1 \\
1\end{array}$ & & . \\
\hline
\end{tabular}




\begin{tabular}{|c|c|c|c|c|c|c|c|}
\hline Number & $\begin{array}{l}\text { Map } \\
\text { ID }\end{array}$ & Easting & Northing & $\begin{array}{l}\text { Basalt } \\
\text { Elevation }\end{array}$ & $\operatorname{Ref}$ & $\begin{array}{l}\text { MP } \\
\text { Elev. }\end{array}$ & $\begin{array}{l}\text { Depth } \\
\text { Bel ow } \\
\text { MP }\end{array}$ \\
\hline $\begin{array}{l}636 \\
637 \\
638 \\
639 \\
640 \\
641 \\
642 \\
643 \\
644 \\
645 \\
646 \\
647 \\
648 \\
649 \\
650 \\
651 \\
652 \\
653 \\
654 \\
655 \\
656 \\
657 \\
658 \\
659 \\
660 \\
661 \\
662 \\
663 \\
664 \\
665 \\
666 \\
667 \\
668 \\
669 \\
670 \\
671 \\
672 \\
673 \\
674 \\
675 \\
676 \\
677 \\
678 \\
679 \\
680 \\
681 \\
682 \\
683 \\
684\end{array}$ & $\begin{array}{l}636 \\
637 \\
638 \\
639 \\
640 \\
641 \\
642 \\
643 \\
644 \\
645 \\
646 \\
647 \\
648 \\
649 \\
650 \\
651 \\
652 \\
653 \\
654 \\
655 \\
656 \\
657 \\
658 \\
659 \\
660 \\
661 \\
662 \\
663 \\
664 \\
665 \\
666 \\
667 \\
668 \\
669 \\
670 \\
671 \\
672 \\
673 \\
674 \\
675 \\
676 \\
677 \\
678 \\
679 \\
680 \\
681 \\
682 \\
683 \\
684\end{array}$ & $\begin{array}{l}267276.0 \\
266396.0 \\
266423.8 \\
266818.4 \\
267448.8 \\
266847.2 \\
266748.3 \\
267463.9 \\
267941.1 \\
266762.7 \\
267776.0 \\
267509.7 \\
267505.5 \\
267667.8 \\
266621.9 \\
267479.0 \\
267636.0 \\
267751.7 \\
266216.4 \\
267912.8 \\
267907.8 \\
266748.7 \\
266776.1 \\
266396.0 \\
266607.8 \\
267506.0 \\
267640.0 \\
266424.8 \\
266790.2 \\
267725.0 \\
267759.8 \\
267638.0 \\
266777.0 \\
266791.2 \\
267657.4 \\
267516.2 \\
266819.1 \\
267449.4 \\
267520.5 \\
266381.7 \\
267518.7 \\
267400.5 \\
267456.1 \\
267697.7 \\
267926.8 \\
267936.5 \\
267669.9 \\
267654.3 \\
267521.3\end{array}$ & $\begin{array}{l}668807.9 \\
669120.1 \\
669092.4 \\
668947.8 \\
669168.6 \\
668953.9 \\
668974.3 \\
669167.6 \\
668833.9 \\
668985.1 \\
669108.9 \\
669180.4 \\
669105.1 \\
669070.7 \\
669018.4 \\
669166.8 \\
668786.4 \\
668719.4 \\
669186.8 \\
668748.8 \\
668733.8 \\
668990.0 \\
668963.7 \\
669102.9 \\
669023.9 \\
669120.3 \\
668846.5 \\
669109.4 \\
668958.4 \\
669261.8 \\
669094.2 \\
669072.6 \\
668979.9 \\
668974.8 \\
669145.7 \\
669049.6 \\
668964.7 \\
669183.7 \\
669103.9 \\
669108.1 \\
669089.1 \\
668860.8 \\
668797.4 \\
669068.8 \\
668790.9 \\
668819.6 \\
669099.9 \\
669086.2 \\
669119.4\end{array}$ & $\begin{array}{l}4999.0 \\
4999.1 \\
4999.1 \\
4999.1 \\
4999.1 \\
4999.2 \\
4999.2 \\
4999.2 \\
4999.2 \\
4999.3 \\
4999.3 \\
4999.3 \\
4999.3 \\
4999.3 \\
4999.4 \\
4999.4 \\
4999.4 \\
4999.4 \\
4999.5 \\
4999.5 \\
4999.5 \\
4999.6 \\
4999.6 \\
4999.7 \\
4999.7 \\
4999.7 \\
4999.7 \\
4999.8 \\
4999.8 \\
4999.8 \\
4999.8 \\
4999.8 \\
4999.9 \\
4999.9 \\
4999.9 \\
4999.9 \\
5000.0 \\
5000.0 \\
5000.0 \\
5000.1 \\
5000.1 \\
5000.1 \\
5000.1 \\
5000.2 \\
5000.2 \\
5000.2 \\
5000.3 \\
5000.4 \\
5000.4\end{array}$ & $\begin{array}{l}1 \\
1 \\
1 \\
1 \\
1 \\
1 \\
1 \\
1 \\
1 \\
1 \\
1 \\
1 \\
1 \\
1 \\
1 \\
1 \\
1 \\
1 \\
1 \\
1 \\
1 \\
1 \\
1 \\
1 \\
1 \\
1 \\
1 \\
1 \\
1 \\
1 \\
1 \\
1 \\
1 \\
1 \\
1 \\
1 \\
1 \\
1 \\
1 \\
1 \\
1 \\
1 \\
1 \\
1 \\
1 \\
1 \\
1 \\
1 \\
1\end{array}$ & & \\
\hline
\end{tabular}




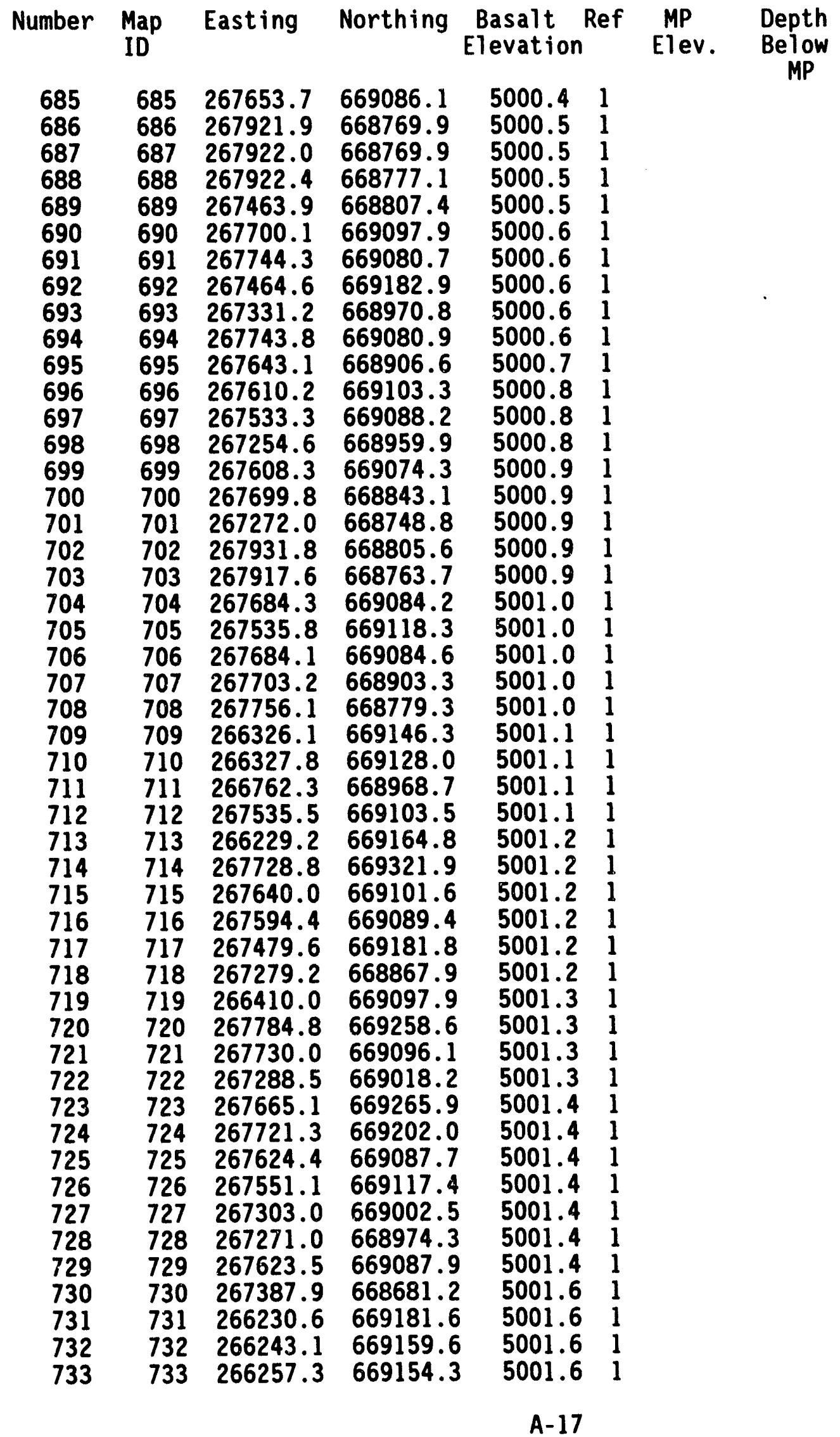




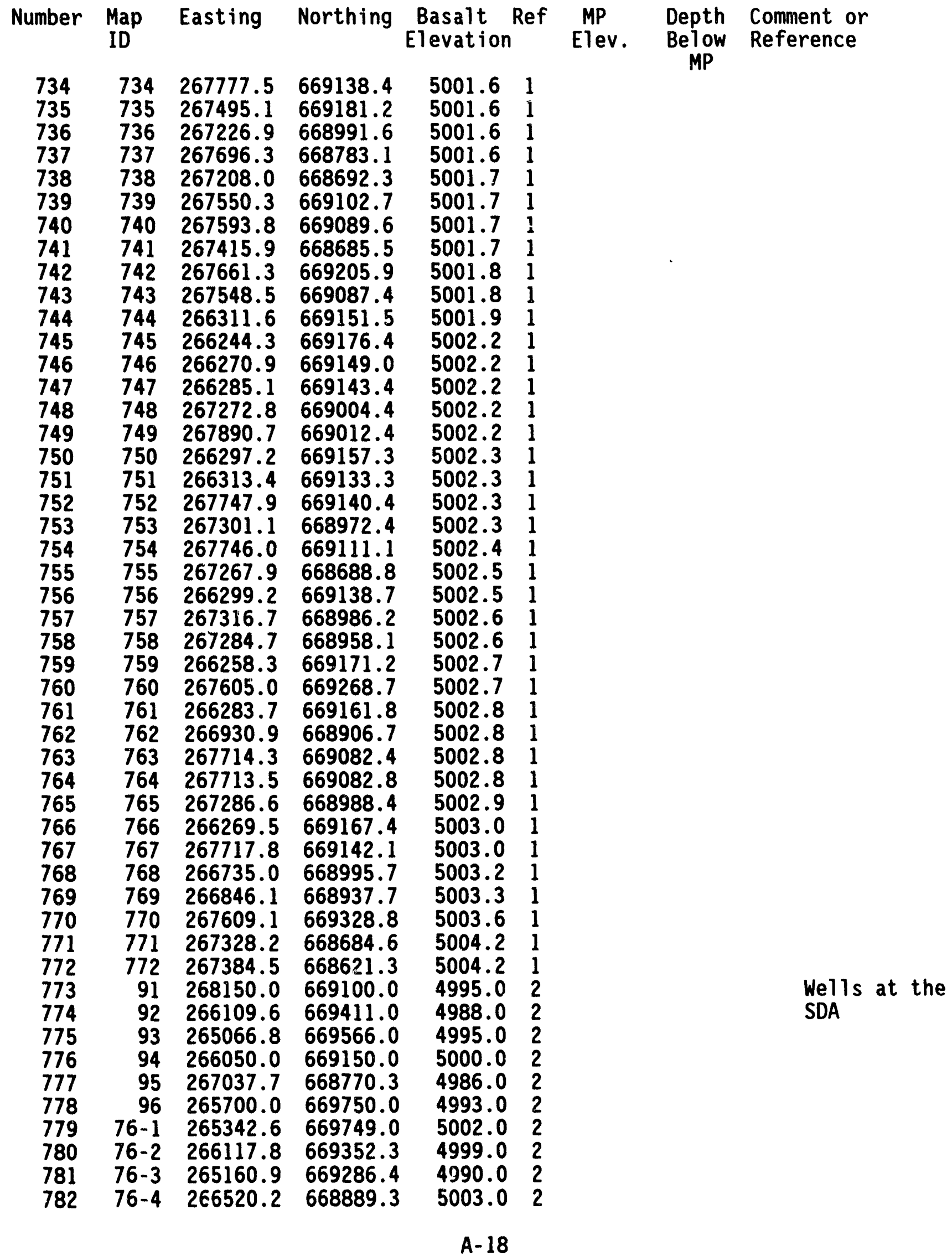




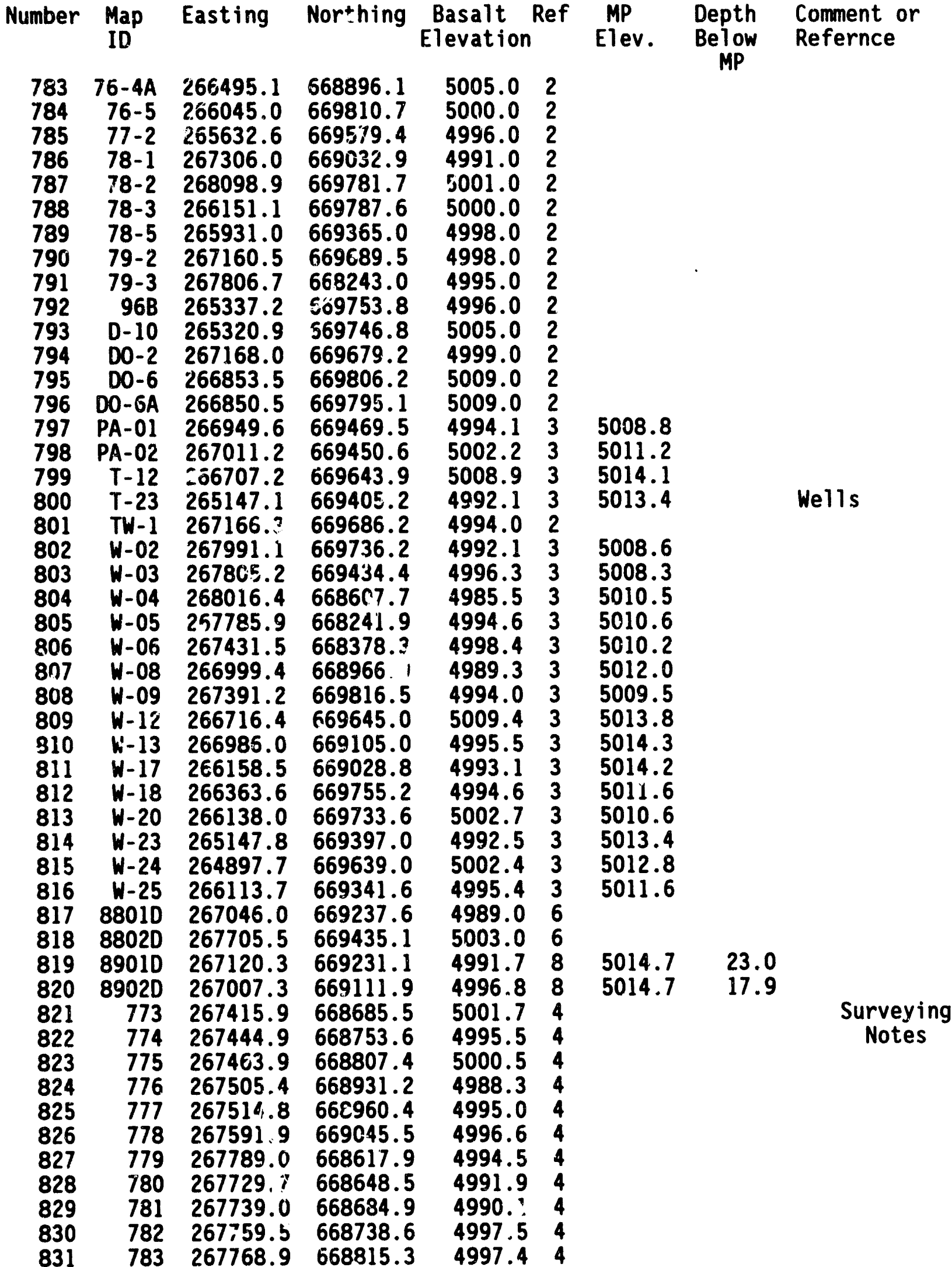




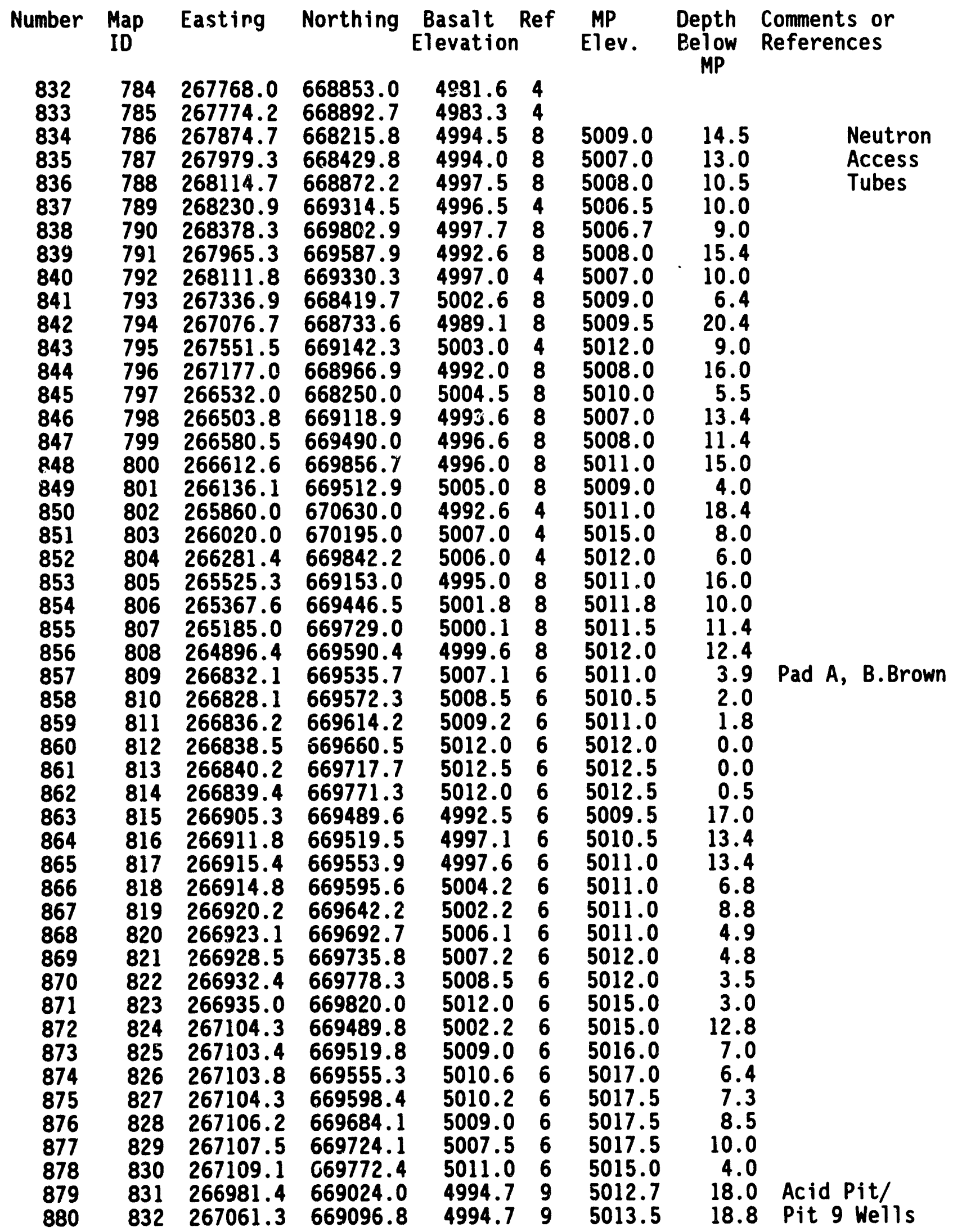




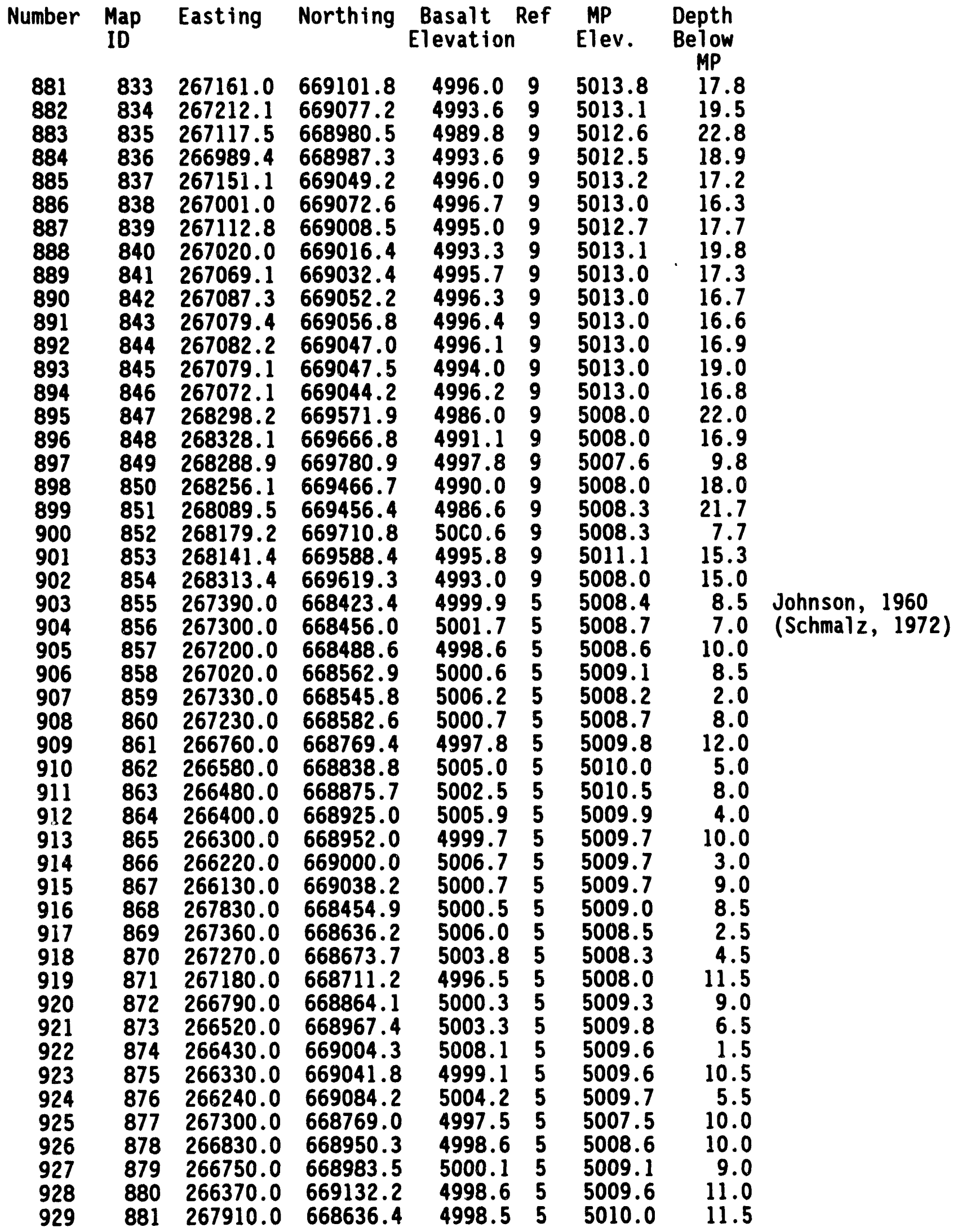




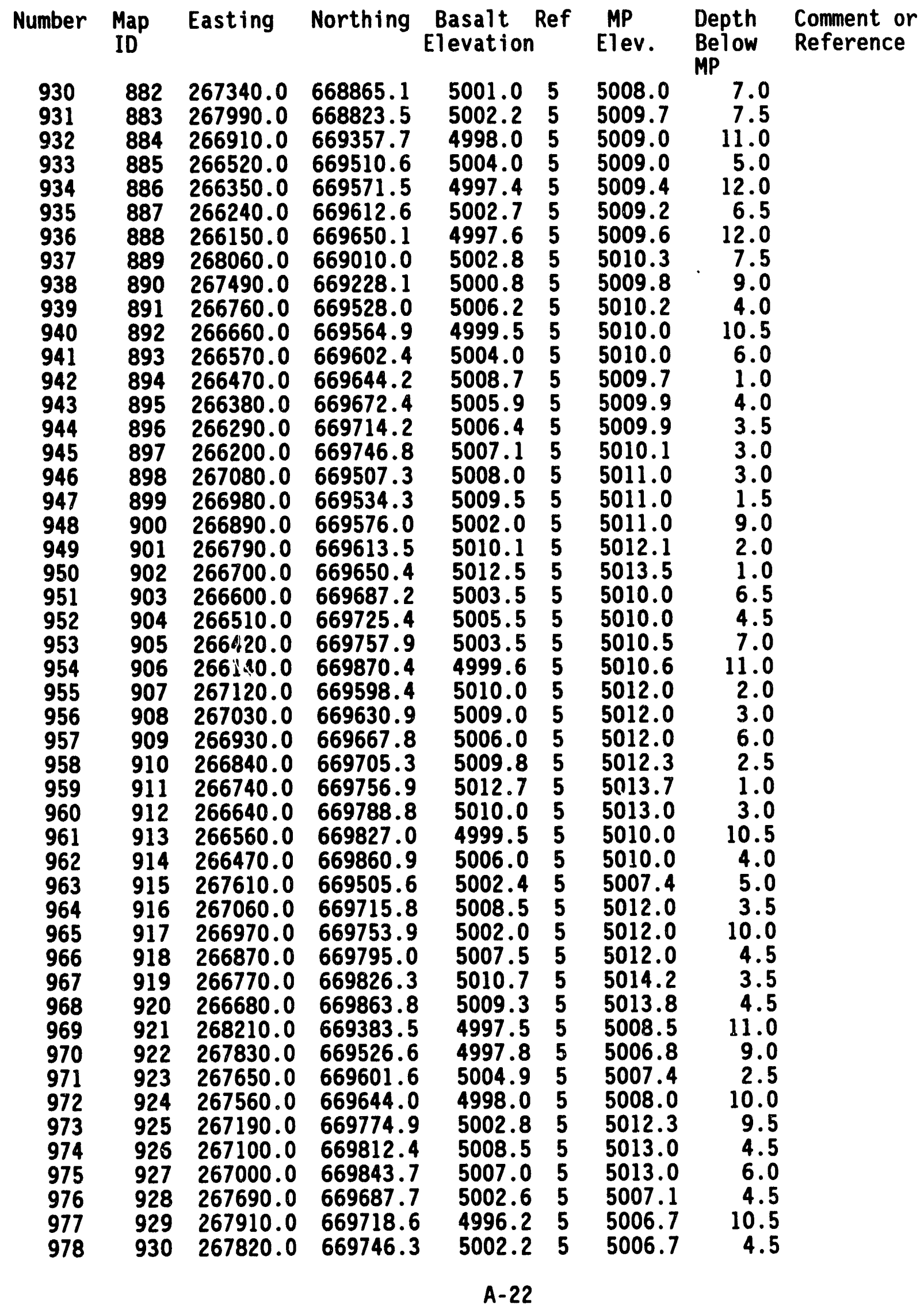




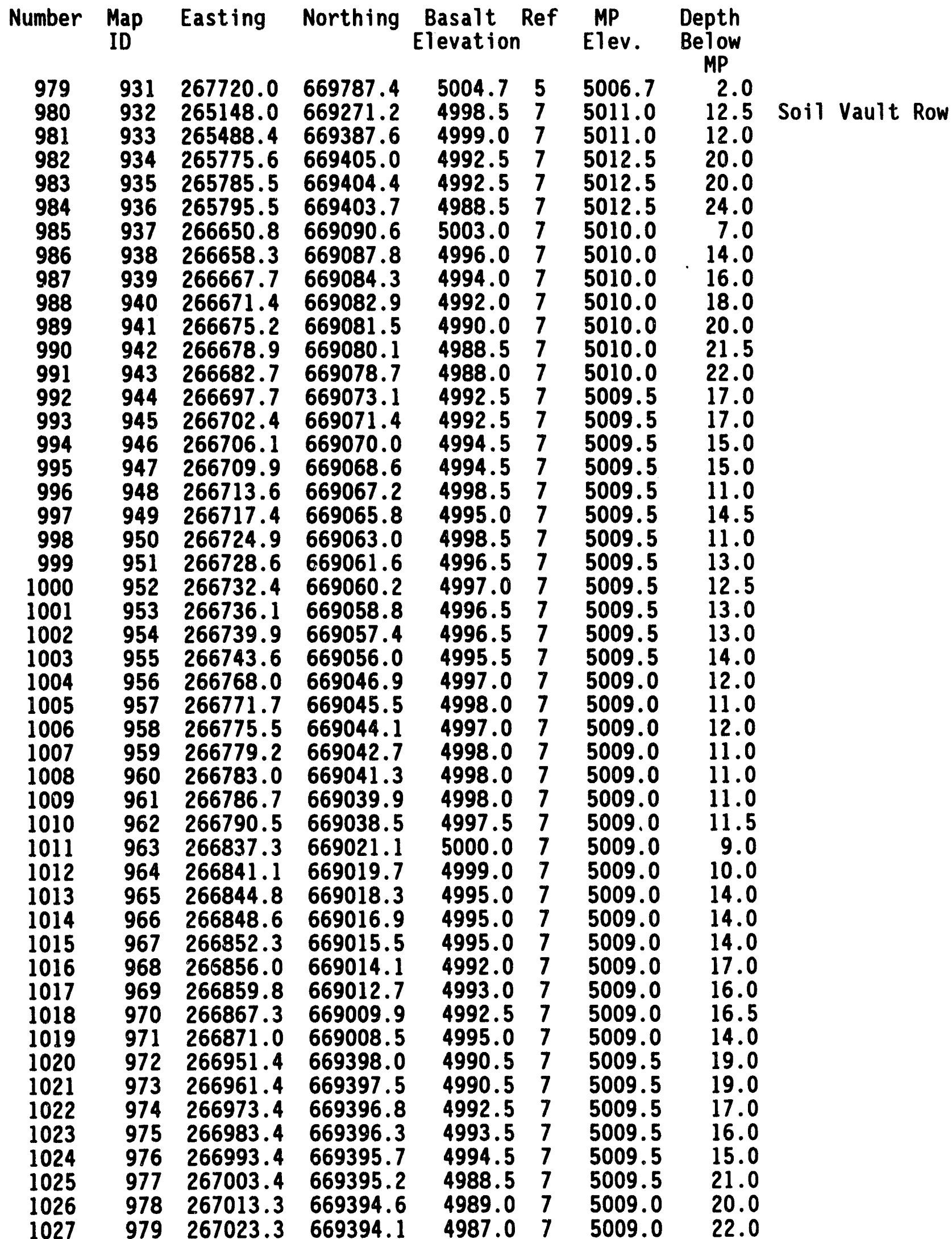




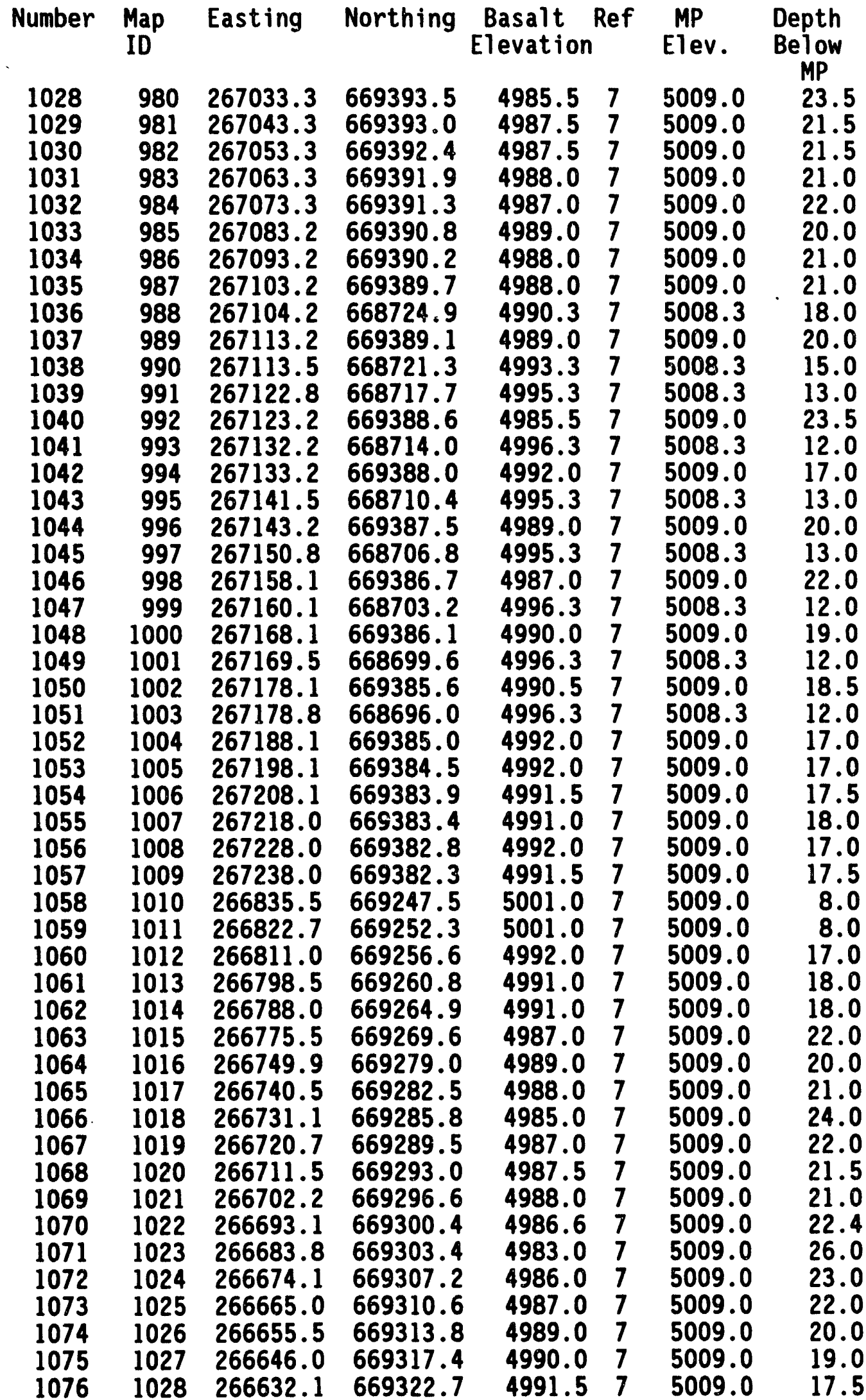




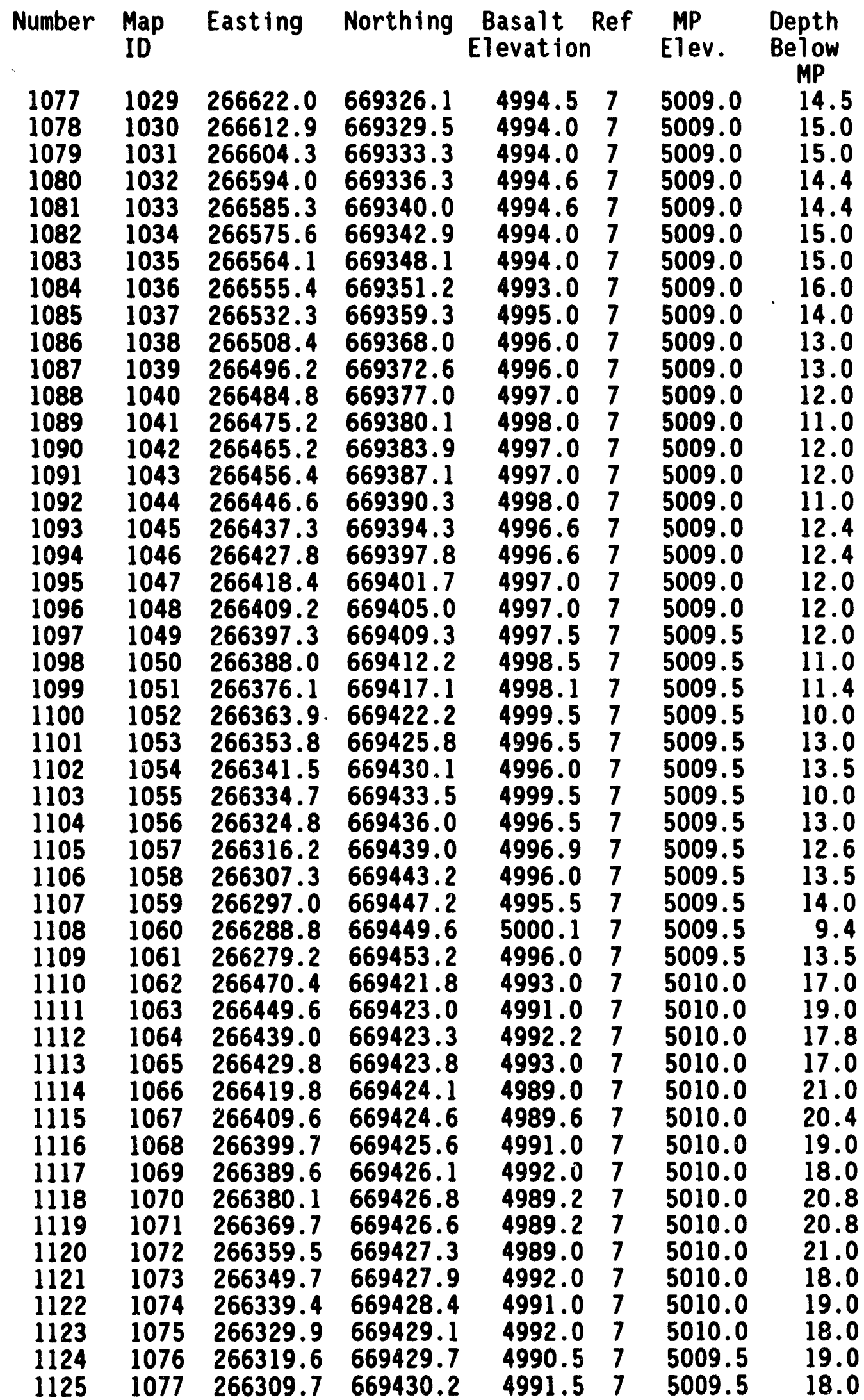




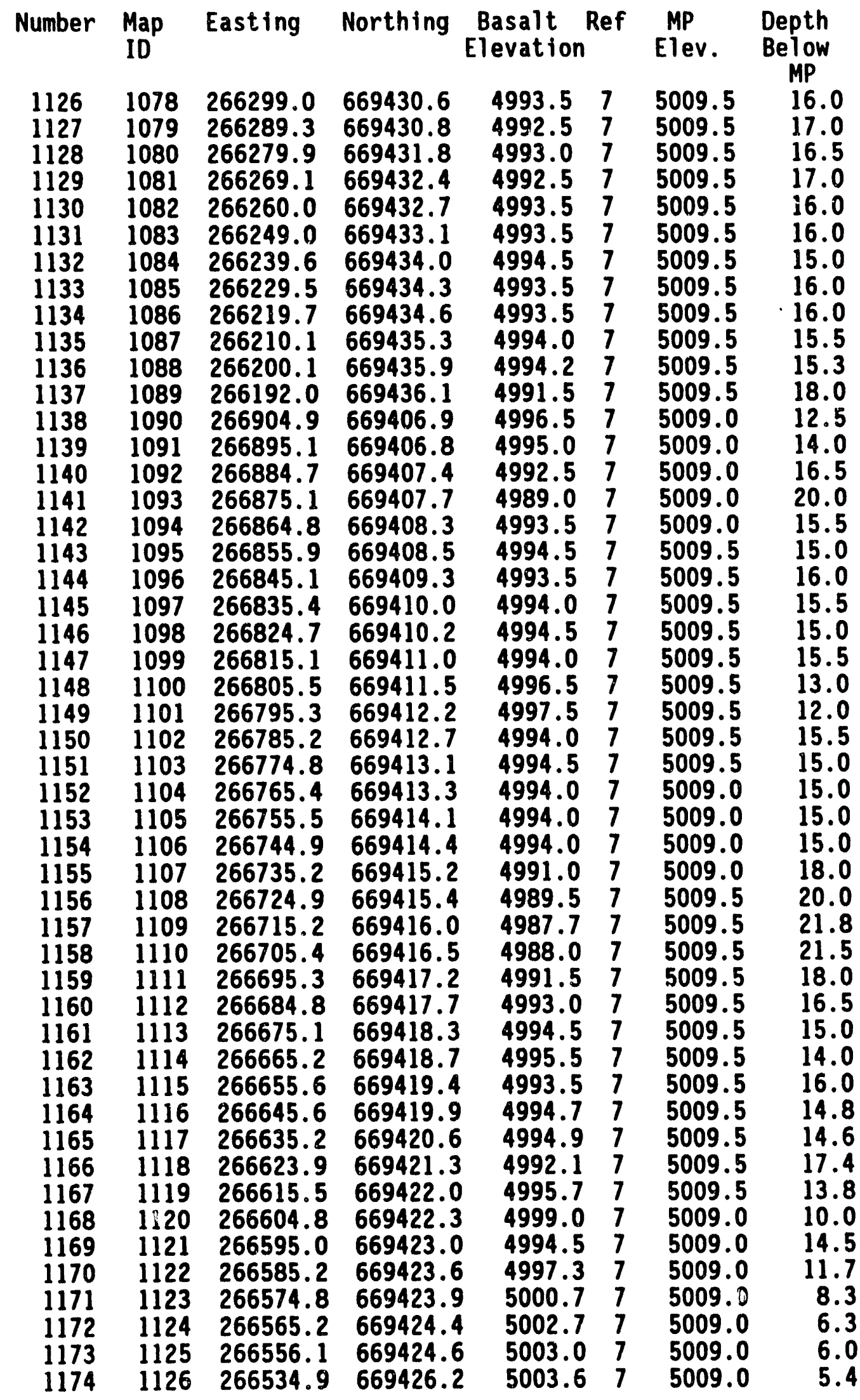




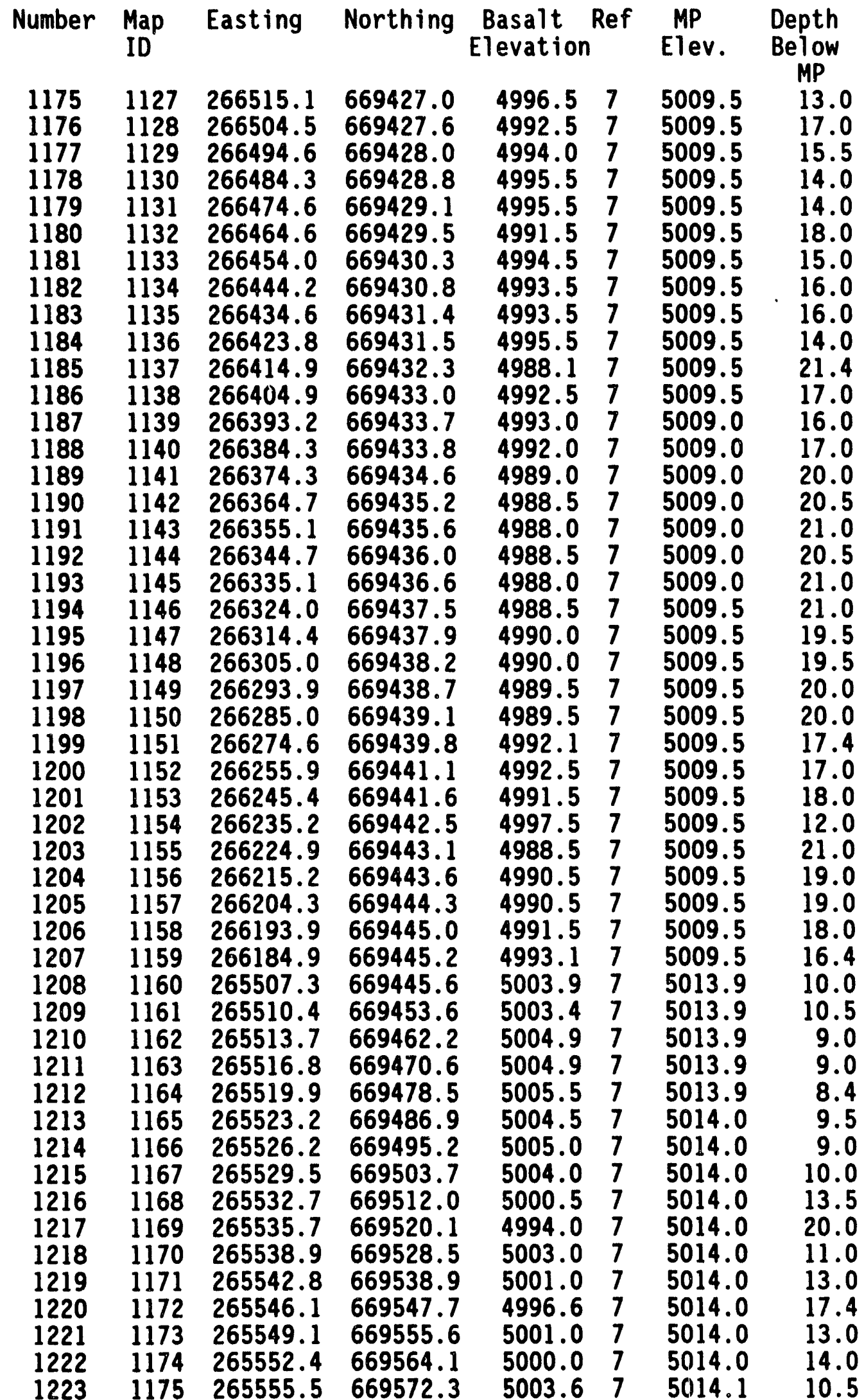




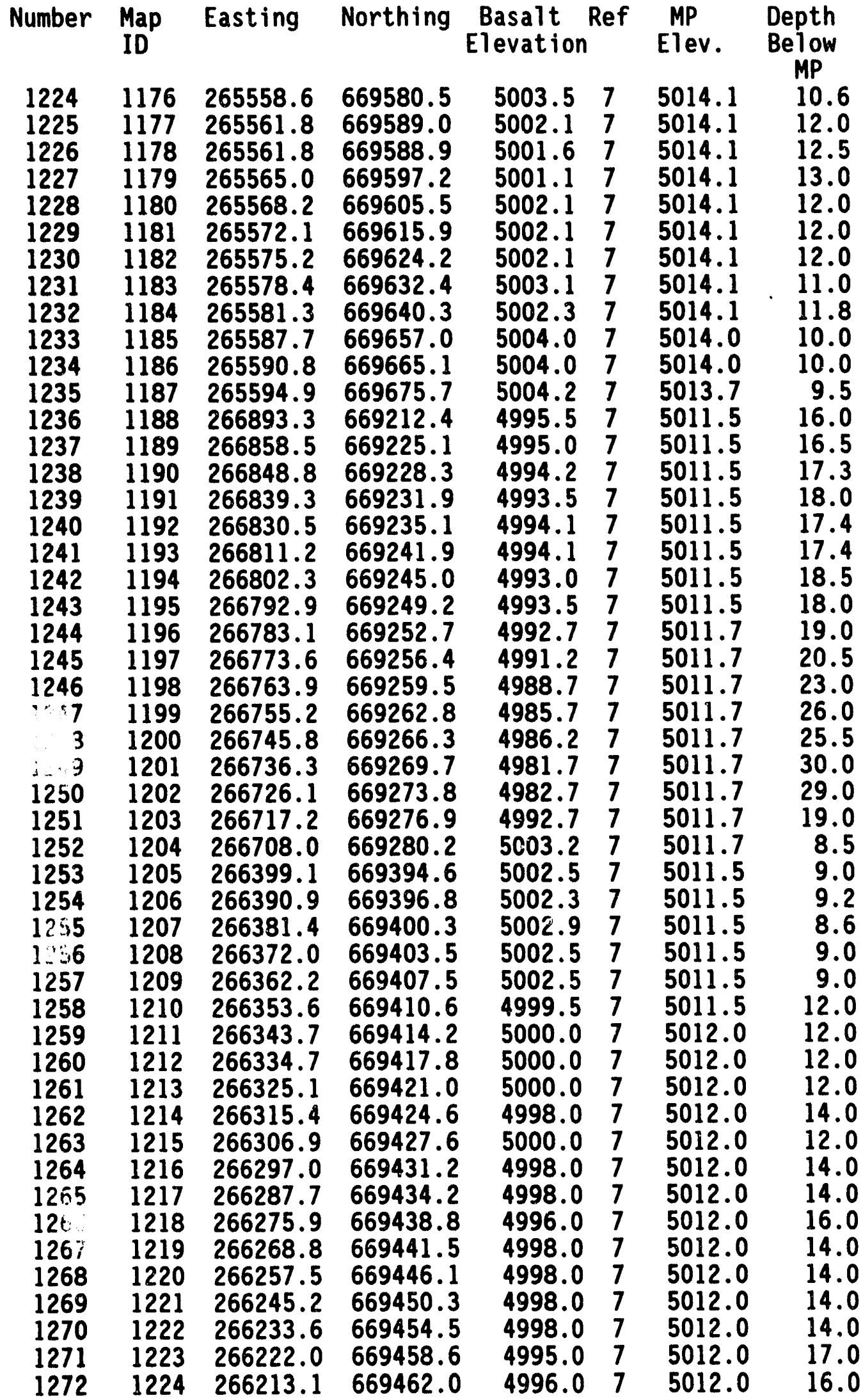




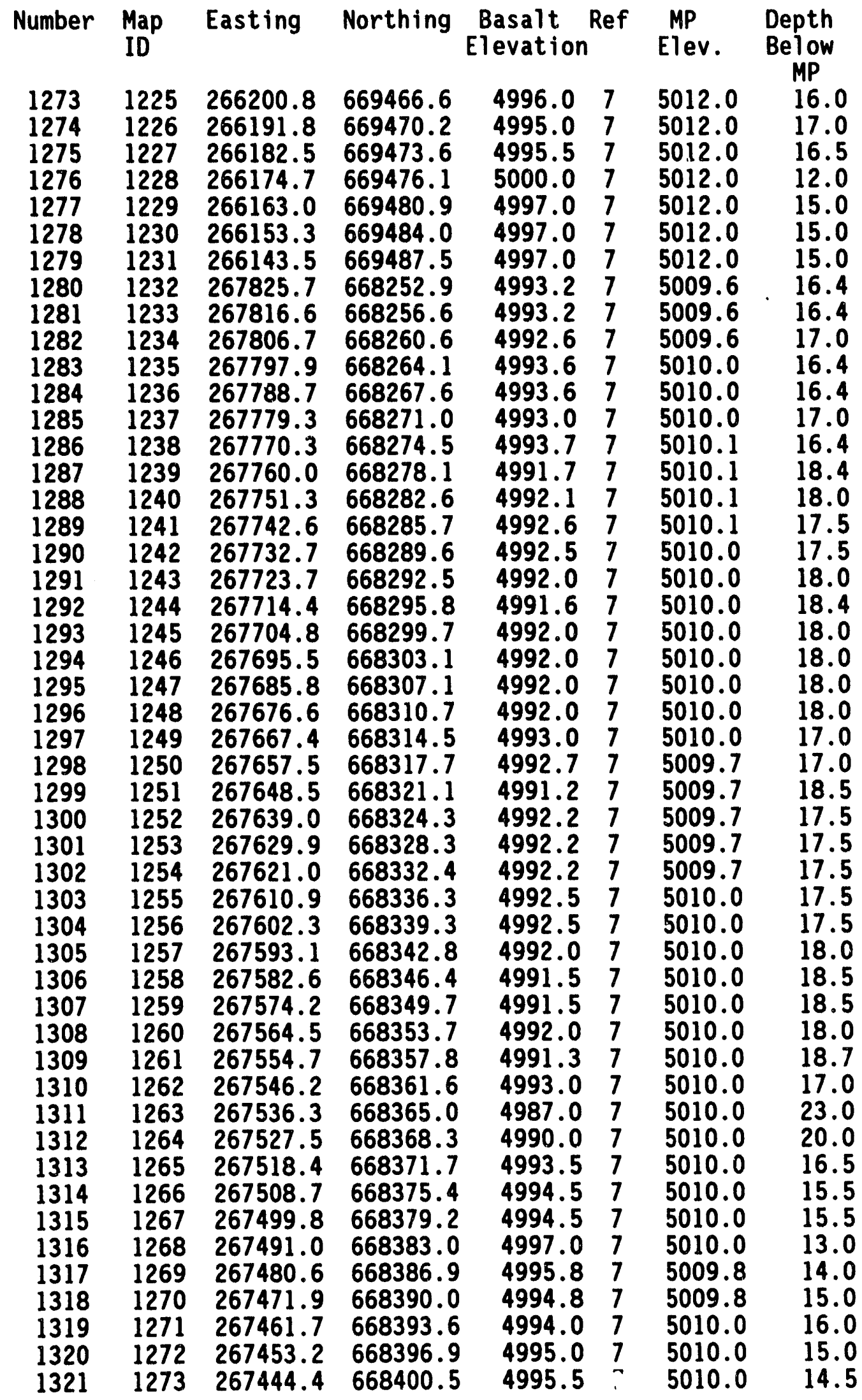




$\begin{array}{llllllll}1322 & 1274 & 267434.0 & 668404.2 & 4996.7 & 7 & 5010.2 & 13.5 \\ 1323 & 1275 & 267425.1 & 668408.1 & 4998.2 & 7 & 5010.2 & 12.0 \\ 1324 & 1276 & 267415.6 & 668411.7 & 4999.2 & 7 & 5010.2 & 11.0 \\ 1325 & 1277 & 267885.2 & 668221.4 & 4992.5 & 7 & 5009.5 & 17.0 \\ 1326 & 1278 & 267876.2 & 668225.1 & 4995.5 & 7 & 5009.5 & 14.0 \\ 1327 & 1279 & 267866.7 & 668229.2 & 4979.5 & 7 & 5009.5 & 30.0 \\ 1328 & 1280 & 267857.3 & 668232.3 & 4996.7 & 7 & 5009.5 & 12.8 \\ 1329 & 1281 & 267848.0 & 668236.1 & 4996.5 & 7 & 5009.5 & 13.0 \\ 1330 & 1282 & 267838.7 & 668239.5 & 4992.5 & 7 & 5009.5 & 17.0 \\ 1331 & 1283 & 267829.2 & 668243.1 & 4992.6 & 7 & 5009.6 & 17.0 \\ 1332 & 1284 & 267820.2 & 668246.7 & 4992.1 & 7 & 5009.6 & 17.5 \\ 1333 & 1285 & 267811.1 & 668249.7 & 4992.6 & 7 & 5009.6 & 17.0 \\ 1334 & 1286 & 267802.0 & 668254.0 & 4992.6 & 7 & 5009.6 & 17.0 \\ 1335 & 1287 & 267793.3 & 668257.3 & 4992.4 & 7 & 5010.0 & 17.6 \\ 1336 & 1288 & 267783.1 & 668261.2 & 4992.0 & 7 & 5010.0 & 18.0 \\ 1337 & 1289 & 267773.9 & 668264.8 & 4991.0 & 7 & 5010.0 & 19.0 \\ 1338 & 1290 & 267765.1 & 668267.9 & 4992.0 & 7 & 5010.0 & 18.0 \\ 1339 & 1291 & 267746.0 & 668274.9 & 4992.0 & 7 & 5010.0 & 18.0 \\ 1340 & 1292 & 267736.6 & 668279.2 & 4992.5 & 7 & 5010.0 & 17.5\end{array}$

Files from Johnson, 1960 (not used in drawings) All Depths $>12.5 \mathrm{ft}$

$\begin{array}{lllllll}1341 & 267760.0 & 668269.2 & 4996.6 & 5 & 5009.1 & >12.5 \\ 1342 & 267580.0 & 668349.1 & 4995.5 & 5 & 5008.0 & >12.5 \\ 1343 & 266950.0 & 668690.2 & 4996.9 & 5 & 5009.4 & >12.5 \\ 1344 & 266860.0 & 668727.0 & 4997.0 & 5 & 5009.5 & >12.5 \\ 1345 & 266670.0 & 668802.0 & 4997.7 & 5 & 5010.2 & >12.5 \\ 1346 & 267640.0 & 668524.3 & 4992.5 & 5 & 5005.0 & >12.5 \\ 1347 & 267460.0 & 668604.3 & 4985.0 & 5 & 4997.5 & >12.5 \\ 1348 & 267090.0 & 668748.7 & 4995.8 & 5 & 5008.3 & >12.5 \\ 1349 & 266980.0 & 668784.9 & 4997.0 & 5 & 5009.5 & >12.5 \\ 1350 & 266900.0 & 668823.0 & 4998.0 & 5 & 5010.5 & >12.5 \\ 1351 & 266710.0 & 668897.4 & 4997.1 & 5 & 5009.6 & >12.5 \\ 1352 & 266620.0 & 668934.8 & 4997.5 & 5 & 5010.0 & >12.5 \\ 1353 & 266160.0 & 669117.4 & 4997.3 & 5 & 5009.8 & >12.5 \\ 1354 & 267400.0 & 668737.1 & 4995.1 & 5 & 5007.6 & >12.5 \\ 1355 & 266560.0 & 669058.5 & 4997.5 & 5 & 5010.0 & >12.5 \\ 1356 & 266460.0 & 669089.7 & 4997.5 & 5 & 5010.0 & >12.5 \\ 1357 & 266190.0 & 669207.8 & 4996.9 & 5 & 5009.4 & >12.5 \\ 1358 & 267160.0 & 668935.1 & 4995.0 & 5 & 5007.5 & >12.5 \\ 1359 & 266920.0 & 669138.0 & 4996.5 & 5 & 5009.0 & >12.5 \\ 1360 & 266830.0 & 669170.6 & 4996.5 & 5 & 5009.0 & >12.5 \\ 1361 & 266640.0 & 669249.9 & 4997.5 & 5 & 5010.0 & >12.5 \\ 1362 & 266460.0 & 669320.6 & 4996.5 & \mathbf{5} & 5009.0 & >12.5 \\ 1363 & 266270.0 & 669390.0 & 4996.5 & 5 & 5009.0 & >12.5 \\ 1364 & 267790.0 & 668897.2 & 4982.0 & 5 & 4994.5 & >12.5 \\ 1365 & 267420.0 & 669047.2 & 4996.5 & 5 & 5009.0 & >12.5 \\ 1366 & 267230.0 & 669120.9 & 4998.4 & \mathbf{5} & 5010.9 & >12.5 \\ 1367 & 266990.0 & 669319.5 & 4996.5 & \mathbf{5} & 5009.0 & >12.5 \\ 1368 & 266440.0 & 669549.5 & 4997.5 & 5 & 5010.0 & >12.5 \\ 1369 & 267870.0 & 669073.8 & 4979.5 & \mathbf{5} & 4992.0 & >12.5 \\ 1370 & 267310.0 & 669303.1 & 4998.4 & \mathbf{5} & 5010.9 & >12.5 \\ 1371 & 266850.0 & 669491.2 & 4998.4 & 5 & 5010.9 & >12.5\end{array}$




$\begin{array}{cccccccc}\text { Number } & \begin{array}{c}\text { Map } \\ \text { ID }\end{array} & \text { Easting } & \text { Northing } & \begin{array}{c}\text { Basalt } \\ \text { Elevation }\end{array} & \begin{array}{c}\text { Ref } \\ \text { Elev. }\end{array} & \begin{array}{c}\text { Depth } \\ \text { Below } \\ \text { MP }\end{array} \\ 1372 & & 266320.0 & 669804.6 & 4998.3 & 5 & 5010.8 & >12.5 \\ 1373 & 266230.0 & 669837.2 & 4997.4 & 5 & 5009.9 & >12.5 \\ 1374 & 268130.0 & 669201.4 & 4997.0 & 5 & 5009.5 & >12.5 \\ 1375 & 267950.0 & 669265.8 & 5001.4 & 5 & 5013.9 & >12.5 \\ 1376 & 267380.0 & 669489.5 & 4998.7 & 5 & 5011.2 & >12.5 \\ 1377 & 267150.0 & 669683.9 & 4999.5 & 5 & 5012.0 & >12.5 \\ 1378 & 268020.0 & 669456.5 & 4994.0 & 5 & 5006.5 & >12.5 \\ 1379 & 267750.0 & 669559.8 & 4994.5 & 5 & 5007.0 & >12.5 \\ 1380 & 267460.0 & 669675.9 & 4995.6 & 5 & 5008.1 & >12.5 \\ 1381 & 268250.0 & 669479.5 & 4996.5 & 5 & 5009.0 & >12.5 \\ 1382 & 268280.0 & 669568.6 & 4997.0 & 5 & 5009.5 & >12.5 \\ 1383 & 268090.0 & 669642.3 & 4993.8 & 5 & 5006.3 & >12.5 \\ 1384 & 268350.0 & 669755.1 & 4995.0 & 5 & 5007.5 & >12.5\end{array}$


FIGURE 2:

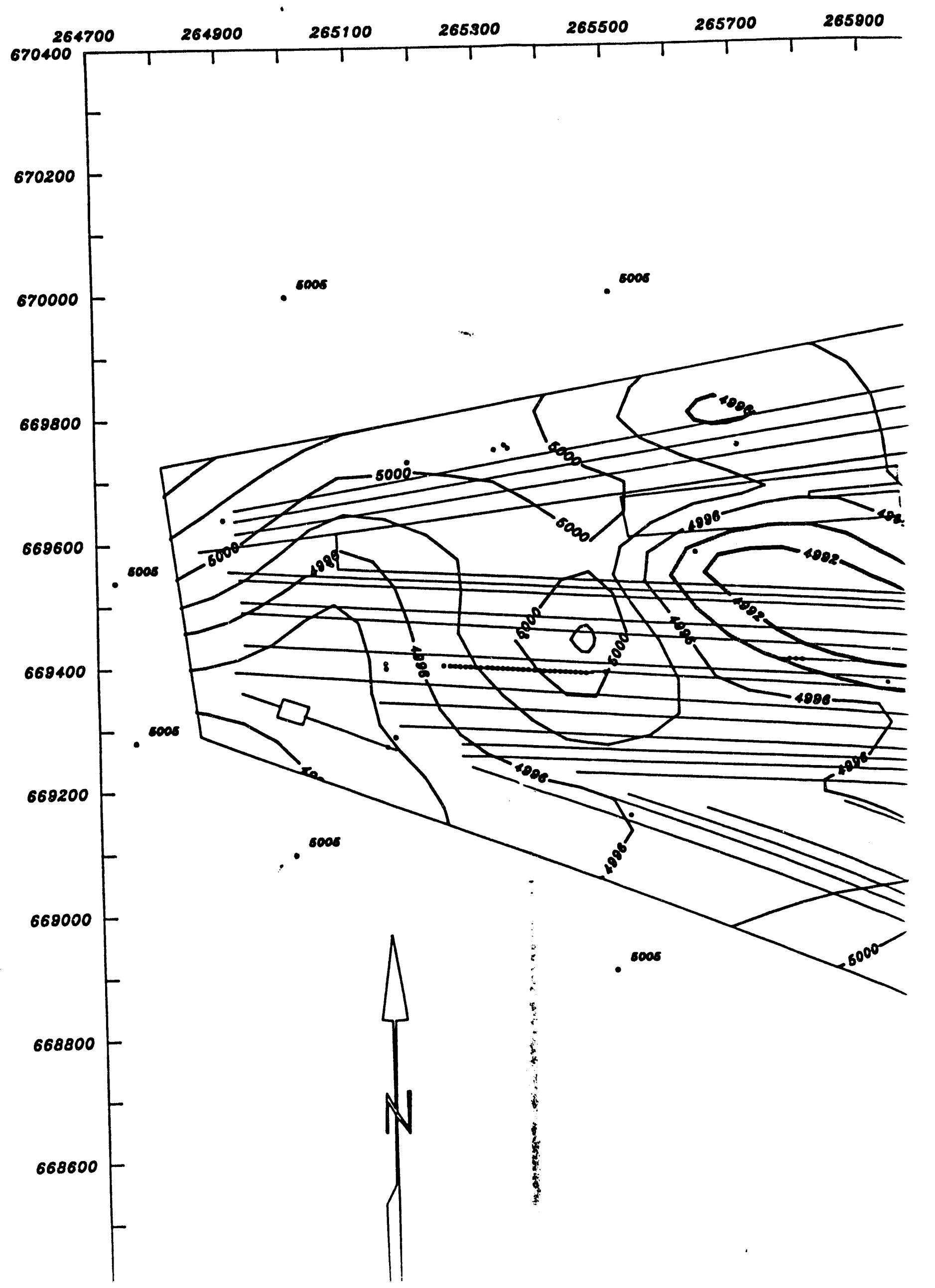


URE 2: Elevation of Surficial Sediment/Basalt Contac:

\begin{tabular}{|c|c|c|c|c|c|c|c|}
\hline 265800 & 266100 & 266300 & 266500 & 266700 & 266900 & 267100 & 267300 \\
\hline
\end{tabular}

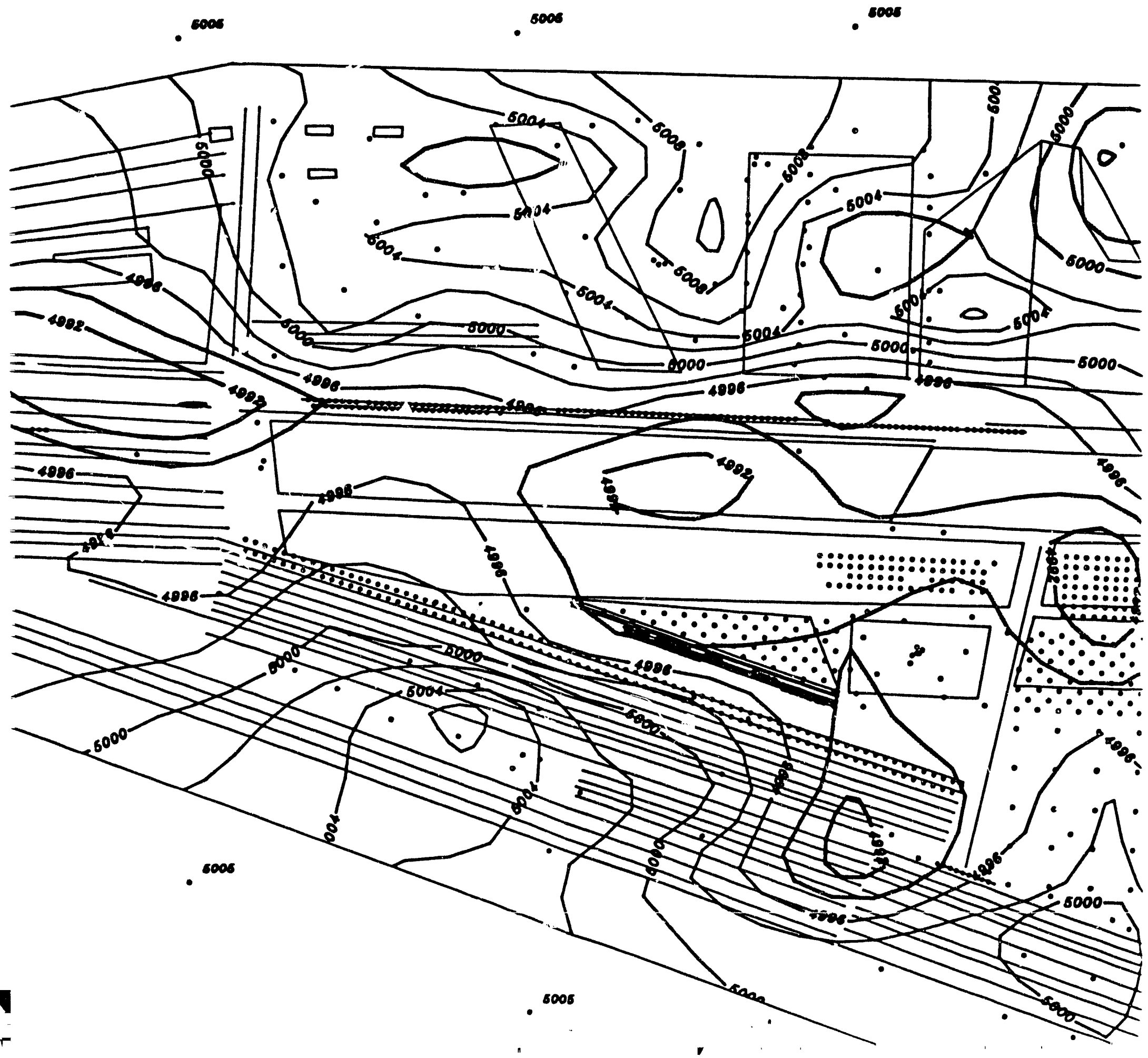


3asalt Contact

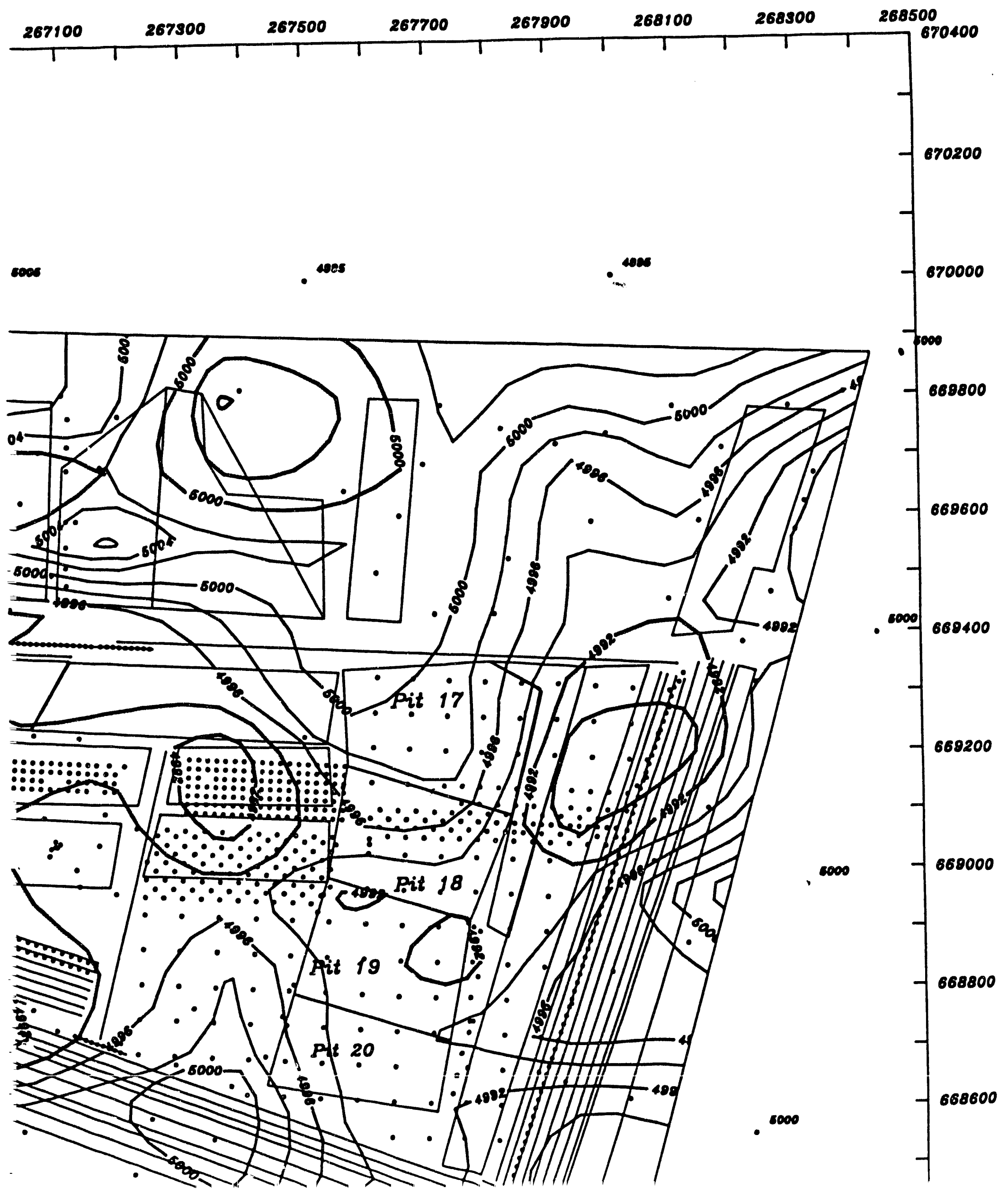




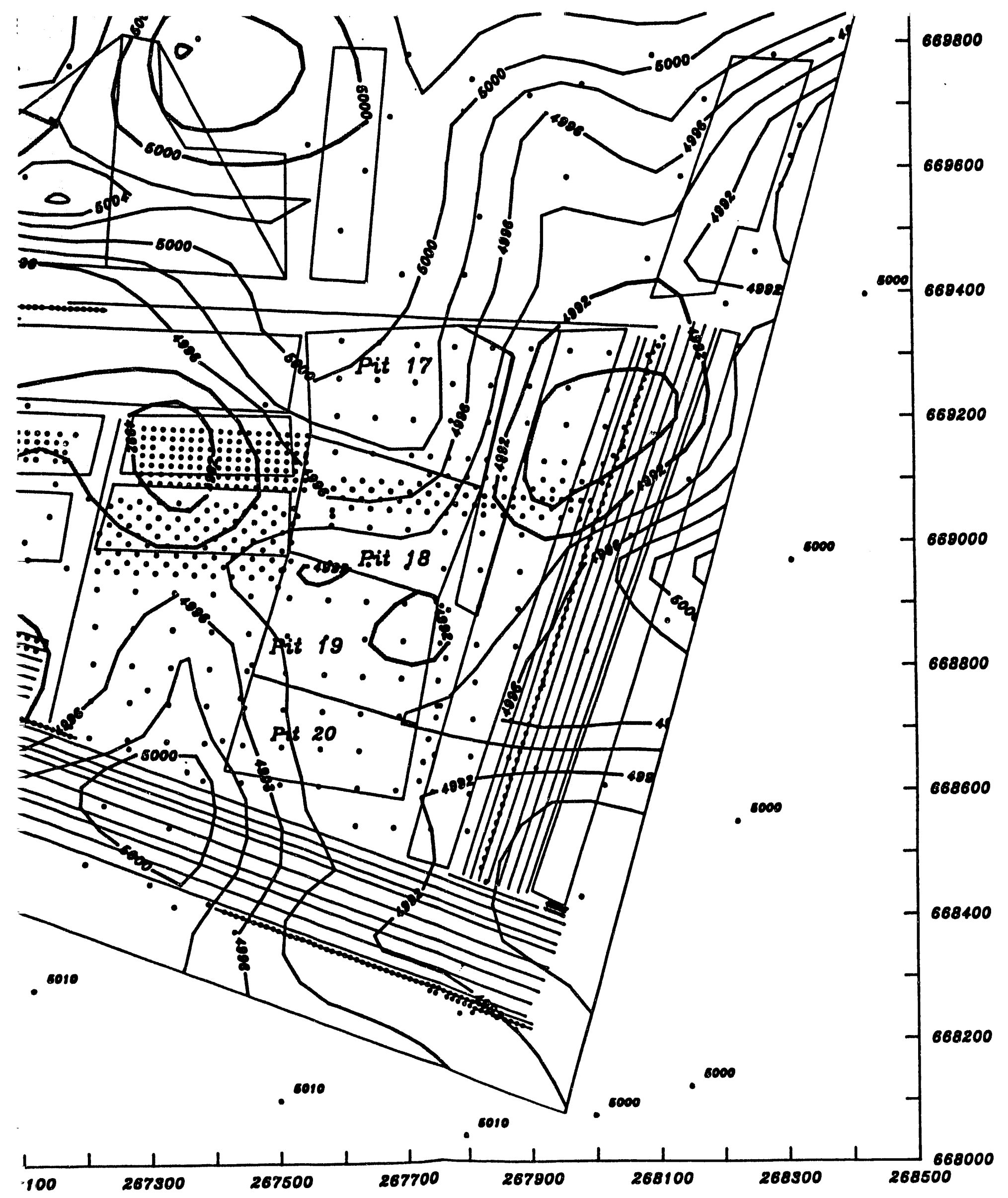




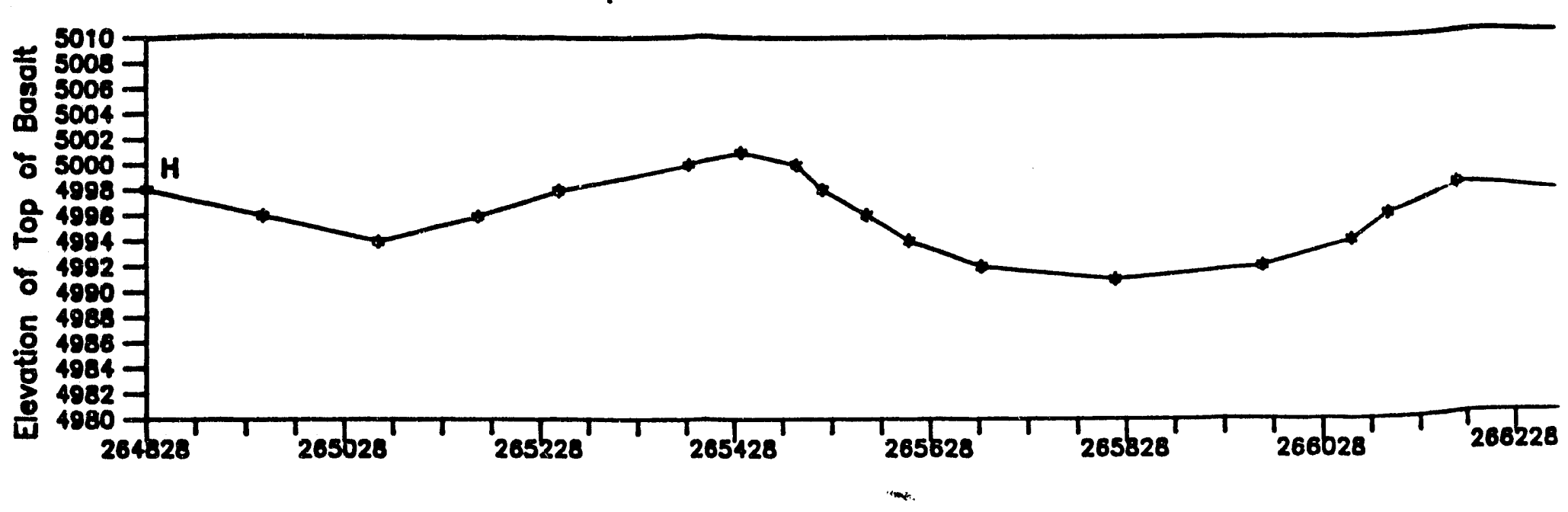

Figure 13. SDA West/East Cross Section: Profile H-H'

FIGURE 3: Elevation of Sur

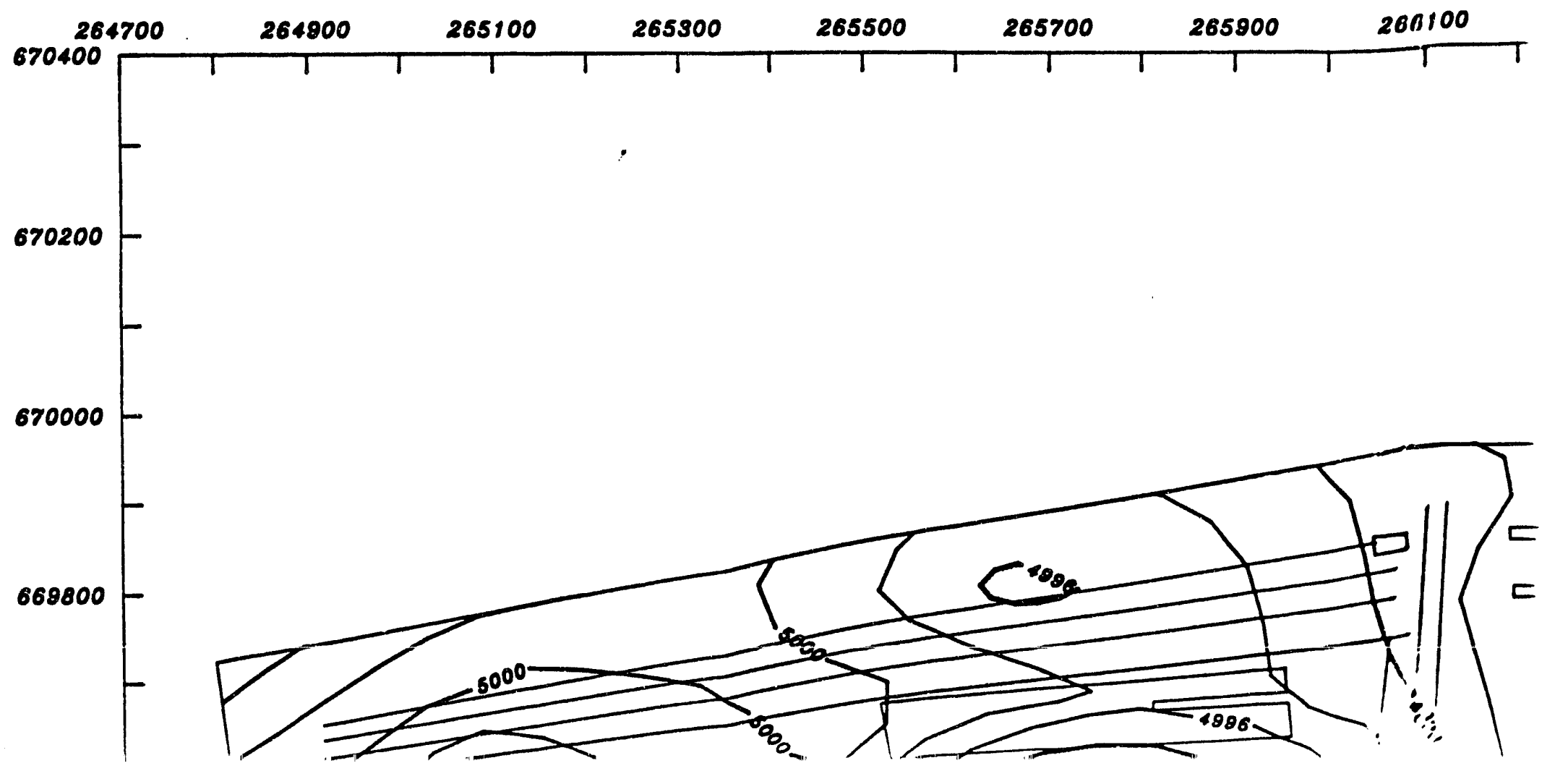




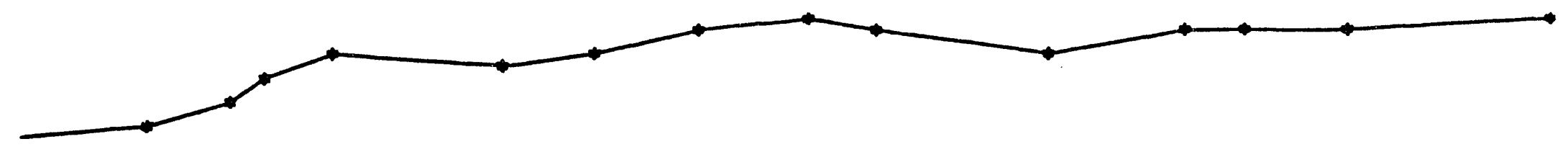

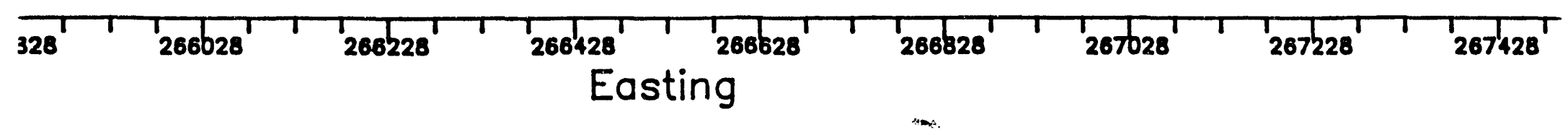

'evation of Surficial Sediment/Basalt Contact (without

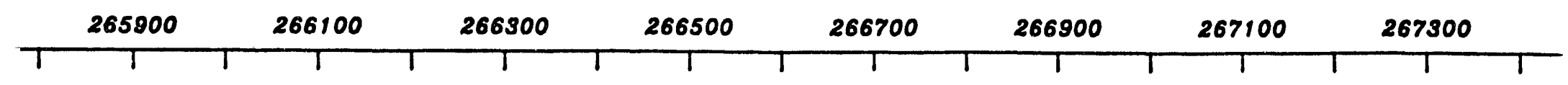

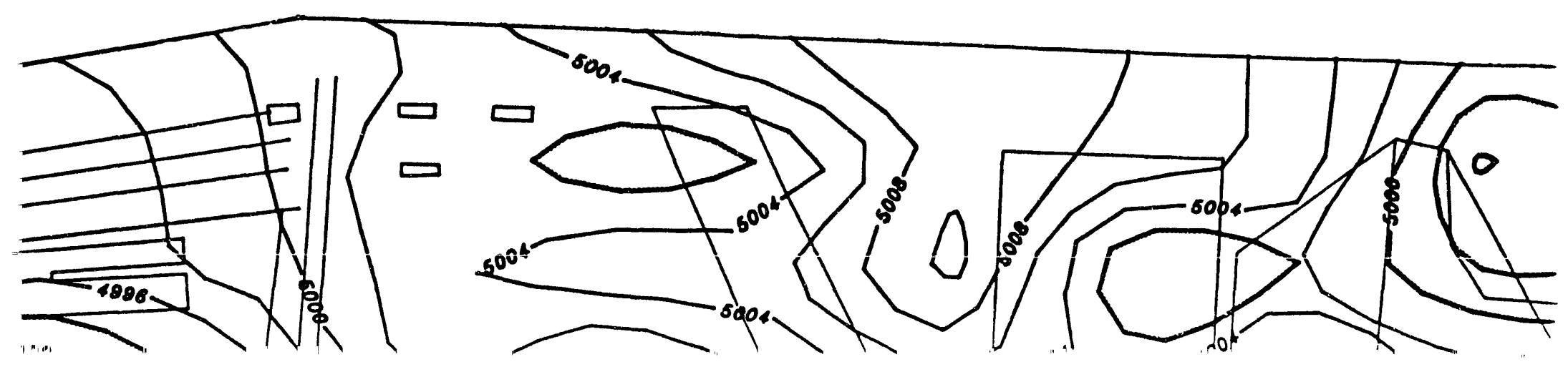


H HUUL उ: HLEVC

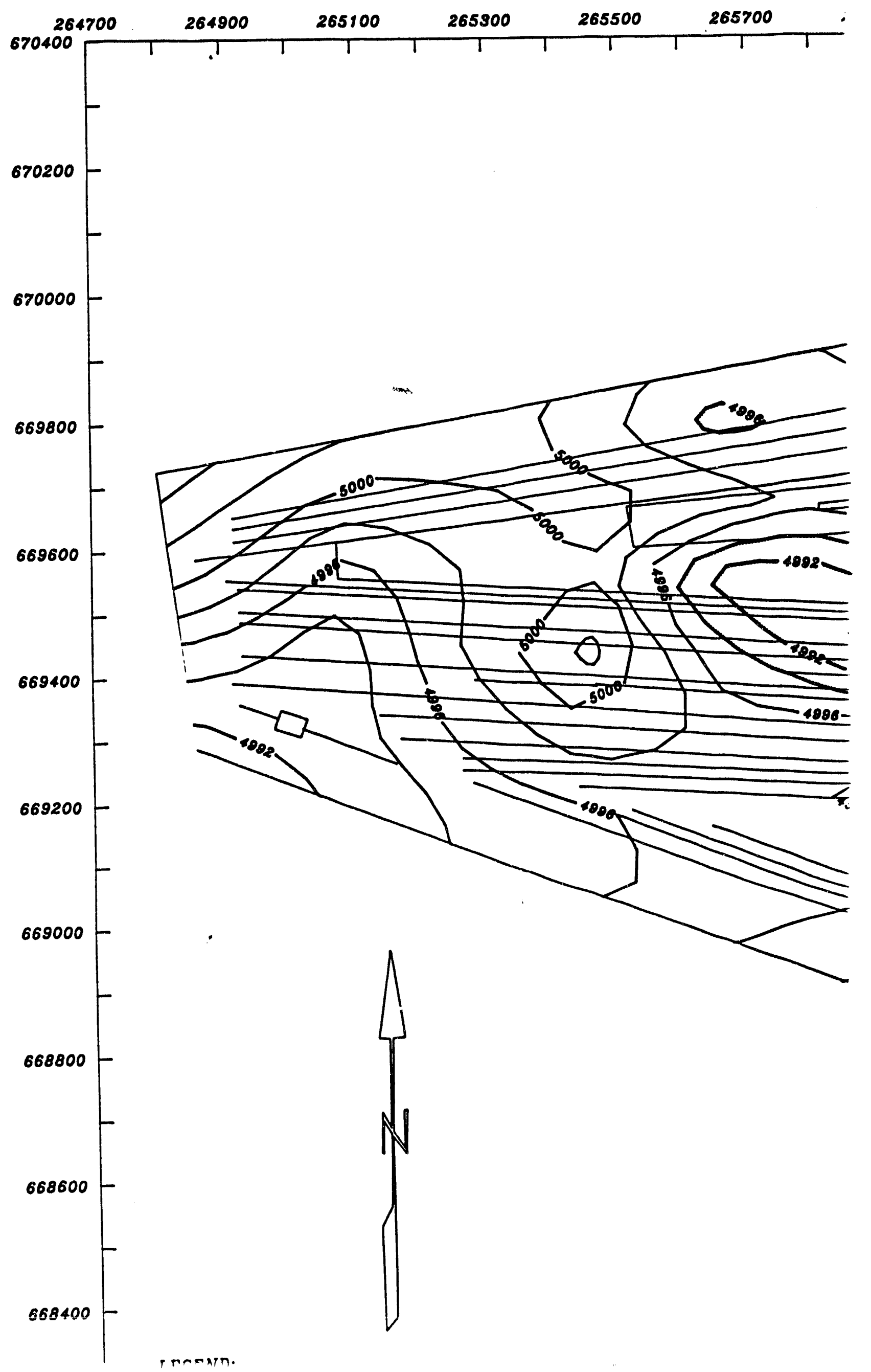


If Surficial Sediment/Basalt Contact (without well poi

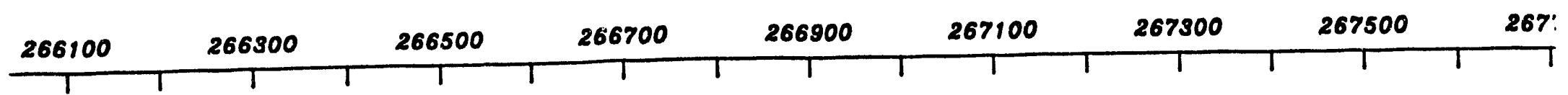

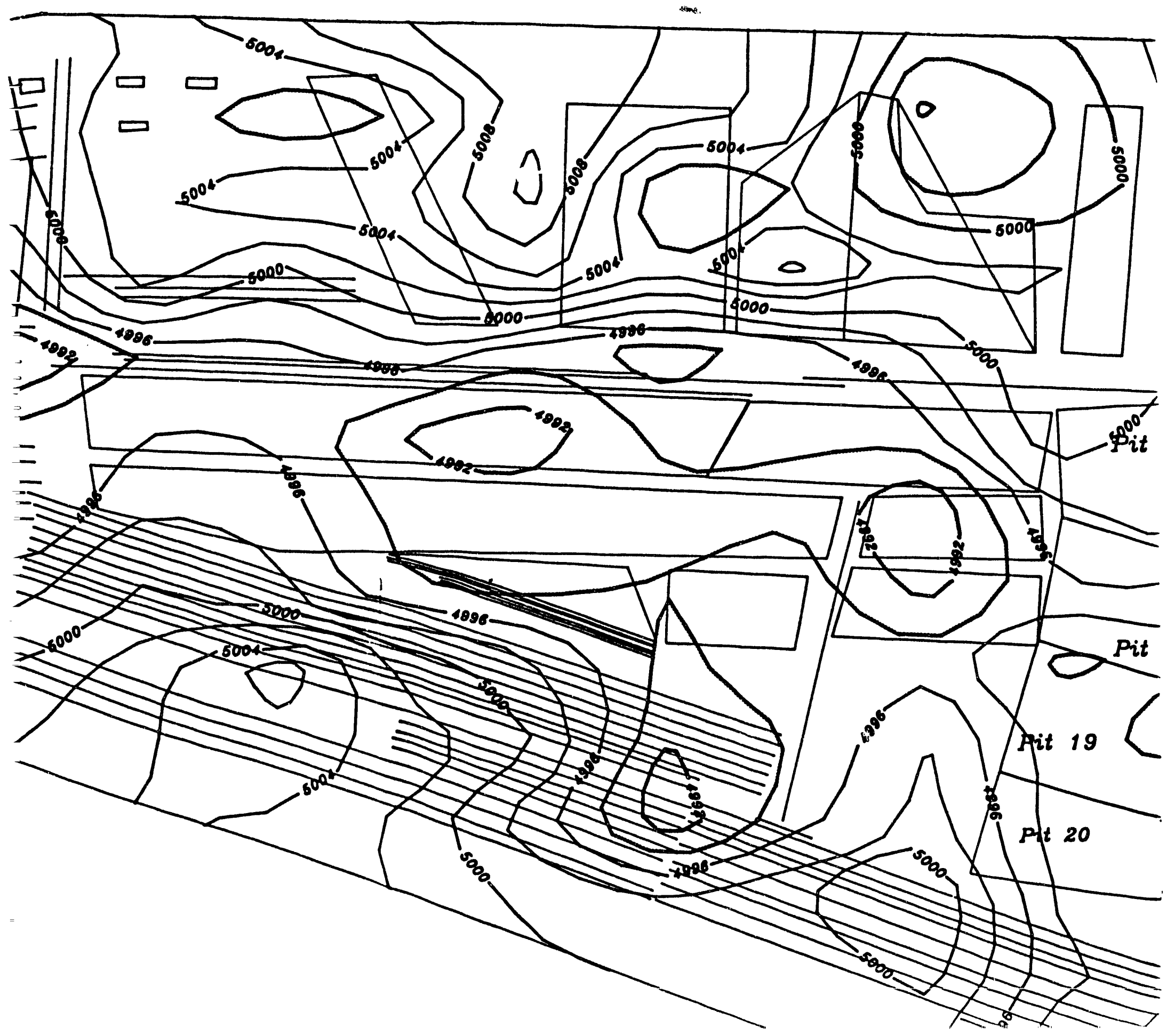


(without well points)

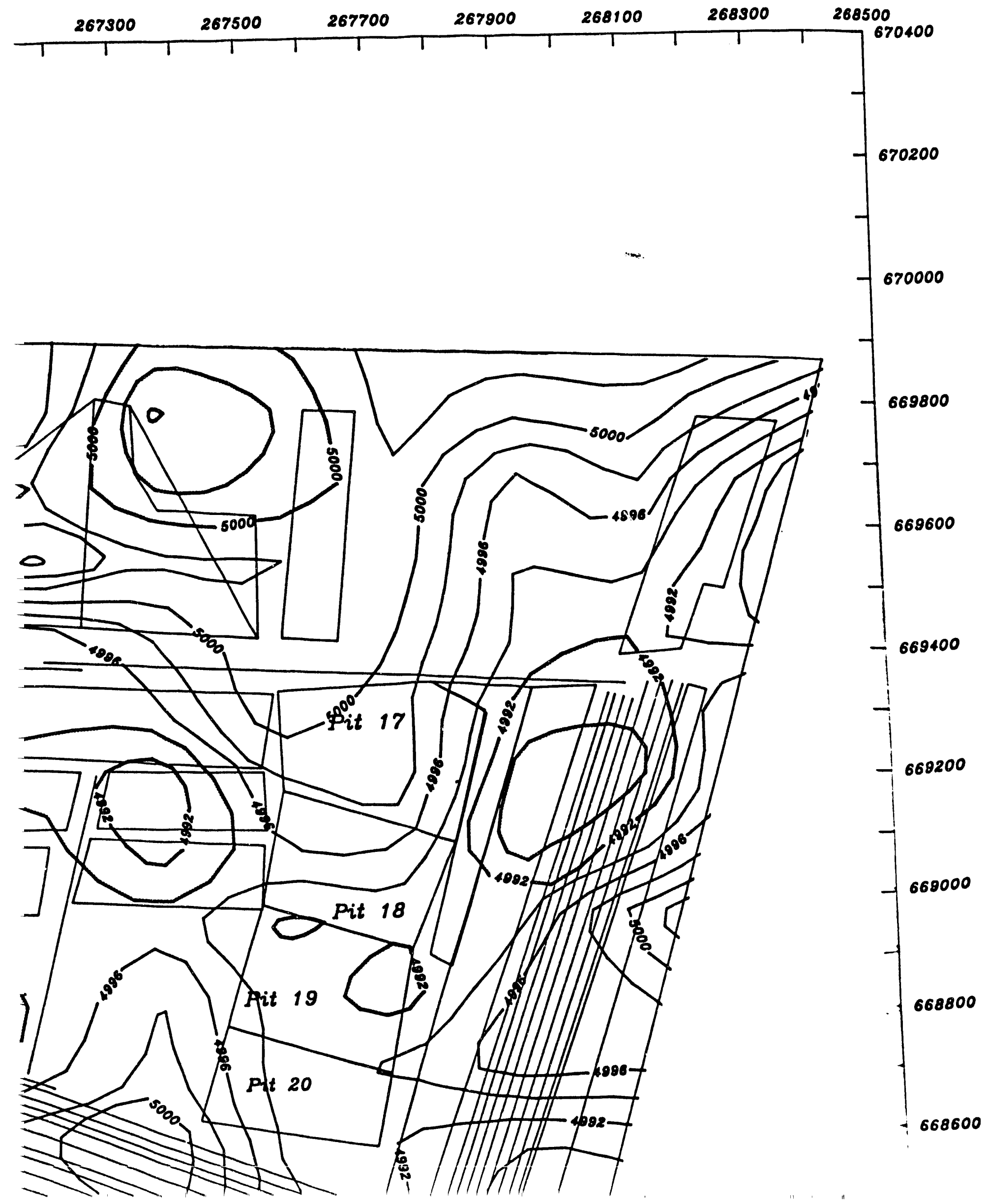




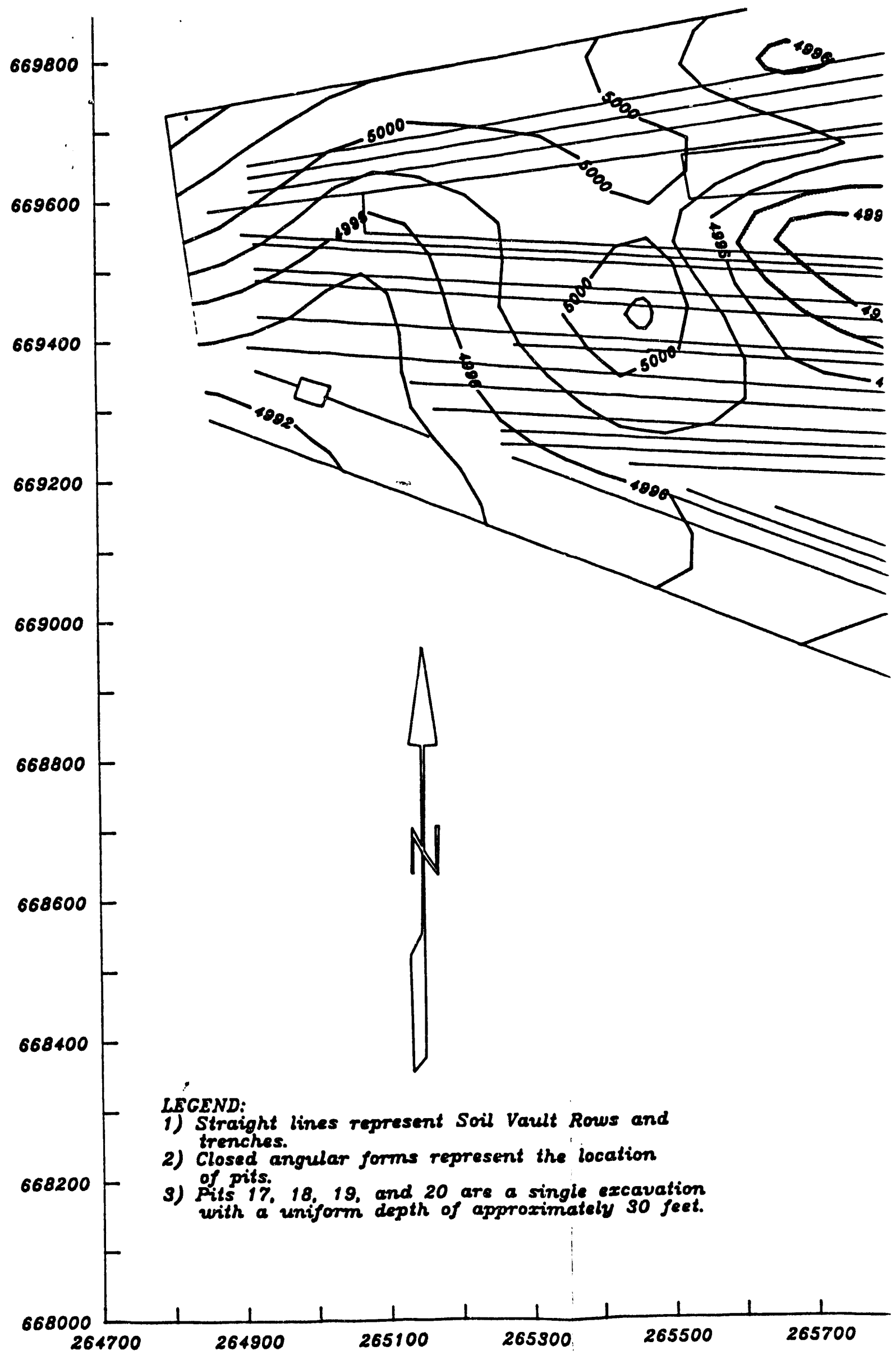




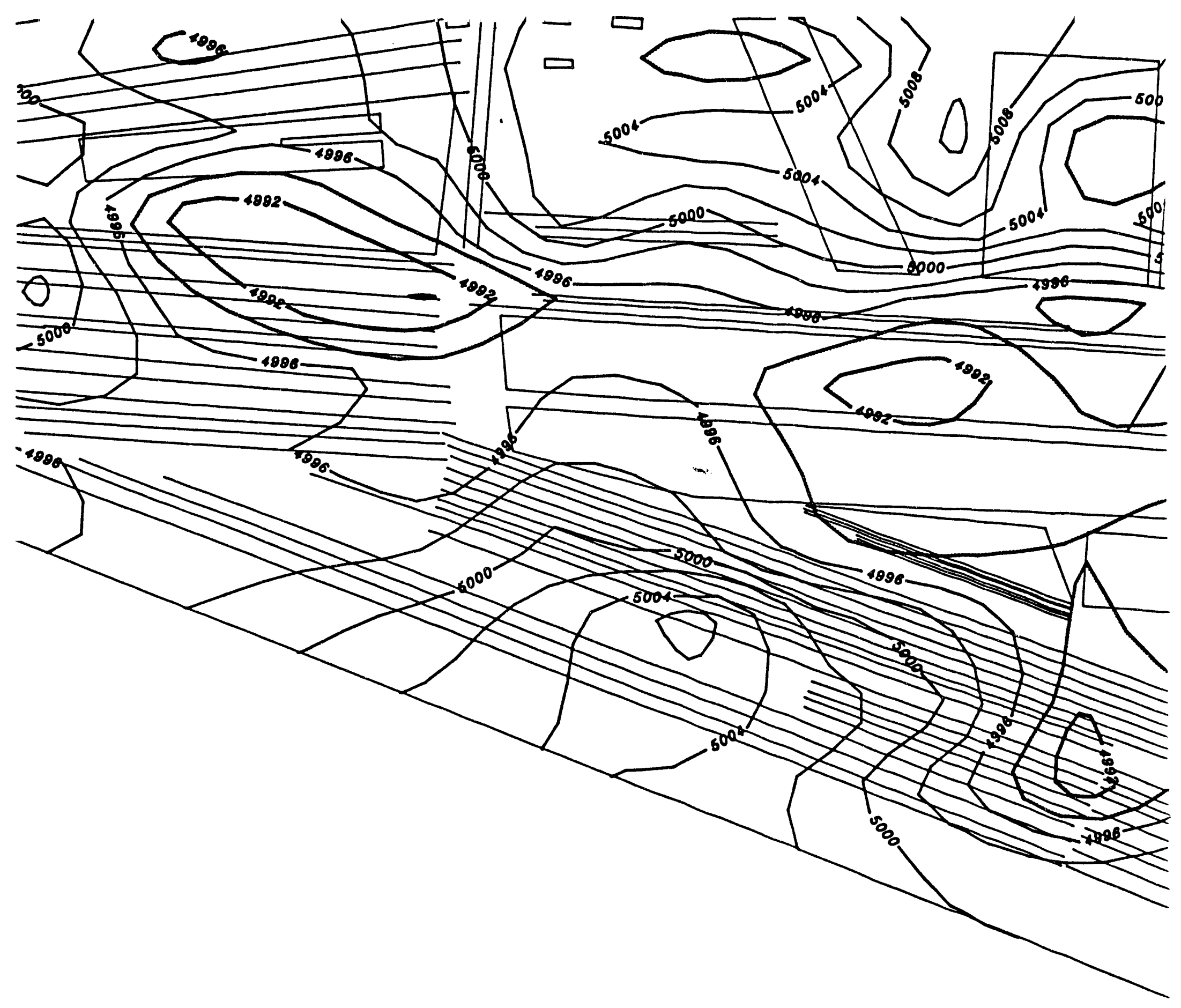

snd

$\boldsymbol{n}$

vation

0 feet.

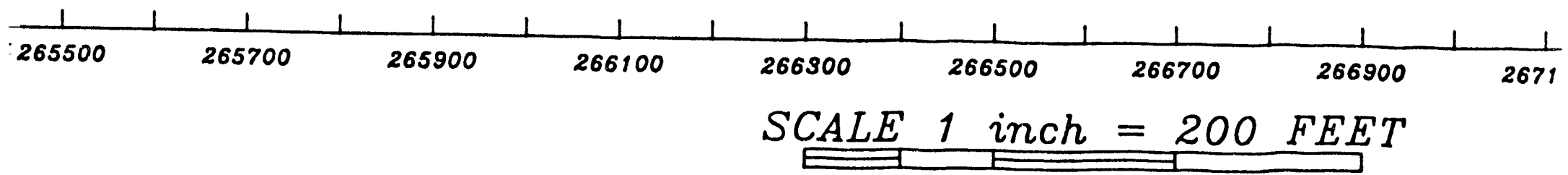



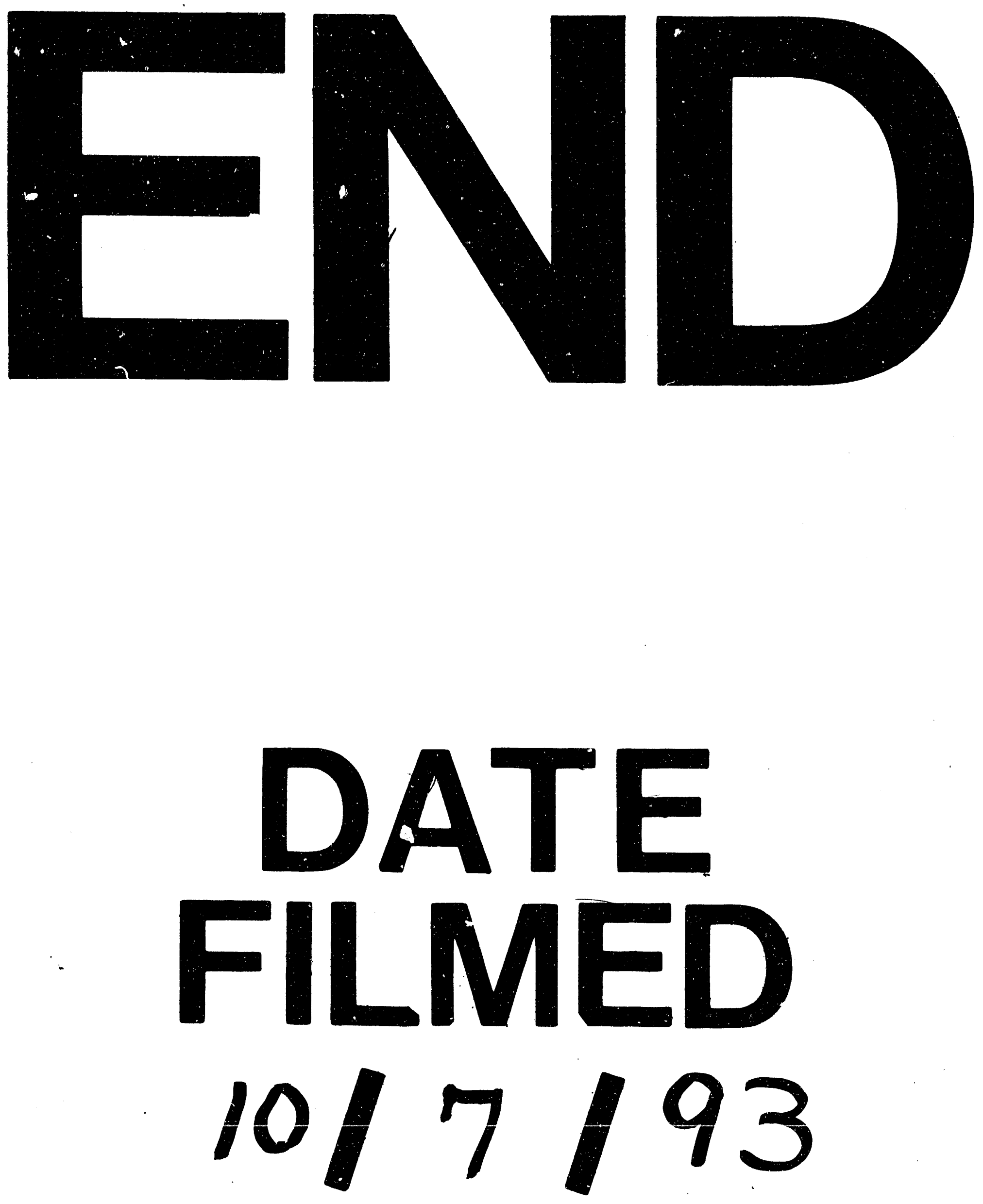

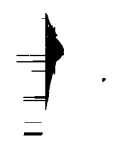


